Florida International University FIU Digital Commons

7-2-2015

\title{
Producing Collaborations Through Community- Level Processes of Climate Change and Water Management Planning
}

Dumitrita Suzana Mic

CMSuzana@gmail.com

DOI: $10.25148 /$ etd.FIDC000131

Follow this and additional works at: https://digitalcommons.fiu.edu/etd

Part of the Human Geography Commons, Nature and Society Relations Commons, Politics and $\underline{\text { Social Change Commons, Social and Cultural Anthropology Commons, and the Urban Studies and }}$ Planning Commons

\section{Recommended Citation}

Mic, Dumitrita Suzana, "Producing Collaborations Through Community-Level Processes of Climate Change and Water Management Planning" (2015). FIU Electronic Theses and Dissertations. 2170.

https://digitalcommons.fiu.edu/etd/2170 
FLORIDA INTERNATIONAL UNIVESRITY

Miami, Florida

PRODUCING COLLABORATIONS THROUGH COMMUNITY-LEVEL

PROCESSES OF CLIMATE CHANGE AND WATER MANAGEMENT PLANNING

A dissertation submitted in partial fulfillment of

the requirements for the degree of

DOCTOR OF PHILOSOPHY

in

GLOBAL AND SOCIOCULTURAL STUDIES

by

Dumitrita Suzana Mic 
To: Dean Michael R. Heithaus

College of Arts and Sciences

This dissertation, written by Dumitrita Suzana Mic, and entitled Producing Collaborations Through Community-Level Processes of Climate Change and Water Management Planning, having been approved in respect to style and intellectual content, is referred to you for judgment.

We have read this dissertation and recommend that it be approved.

$\begin{array}{r}\hline \text { Hugh Gladwin } \\ \hline \text { Nazife Ganapati } \\ \hline \text { Gail Hollander, Co-Major Professor } \\ \hline \text { Laura Ogden, Co-Major Professor }\end{array}$

Date of Defense: July 2, 2015

The dissertation of Dumitrita Suzana Mic is approved.

\begin{tabular}{r}
\hline $\begin{array}{r}\text { Dean Michael R. Heithaus } \\
\text { College of Arts and Sciences }\end{array}$ \\
\hline Dean Lakshmi N. Reddi \\
University Graduate School
\end{tabular}

Florida International University, 2015 


\section{DEDICATION}

I dedicate this dissertation to my family and friends. I am thankful to Kees Samuels and Berdy Samules-Koning for their support as I began my higher education studies. This intellectual journey would have never started without Mark Gladwin and Tammy Shields. Knowing you and becoming a part of your family has been life changing. I have a special feeling of gratitude to my parents, Dumitru and Ileana Mic, whose push for tenacity was the wind in my sails; ex nihilo nihil fit. My sister, Daniela, even though thousands miles away has never ceased to be at my side and has been my biggest cheerleader. I thank my friends, Fabienne and Armando, for being there for me

during some of the most difficult times, always lending an ear, always with a wise word, always with a smile on their face.

I dedicate this work and give special thanks to Eric Blake, my better half, for bringing so much joy into my life and helping me see this project to its completion. 


\section{ACKNOWLEDGMENTS}

I would like to thank my committee members for their continuous encouragement and support during this intellectual journey. I am particularly thankful that Dr. Laura Ogden, my chair, has continued to support me despite her taking a new, exciting job. Throughout the years she has been incredibly patient and understanding and allowed me to learn at my own pace while making sure that I reached my goals. I am thankful to my co-chair Dr. Gail Hollander for the many hours she has spent with me discussing the intricate and exciting world of climate change. I am grateful for Dr. Nazife Ganapati’s mentorship. Her knowledge of the policy-making world has helped me better prepare for my fieldwork. Finally, I would have not completed this research without the continuous support that Dr. Hugh Gladwin has offered. His commitment to climate justice coupled with an intimate knowledge of Miami and its vulnerabilities has inspired and encouraged me all along the way.

I am indebted to Dr. Obeysekera Jayantha, chief-engineer at the South Florida Water Management District, who graciously welcomed me into his climate-change research team and offered numerous opportunities to learn about South Florida's climatechange impacts and the ways this agency engages them. I am very grateful for all the staff and scientists at the District who were very open and receptive to my research and responded to my many requests for data and documents, and for those who took time to discuss with me the complex world of ecosystem modeling as well as current water management principles and practices. 
This work would not have been possible without support from the National Science Foundation through the Urban Long Term Research Area (Grant No. BCS0948988), the Florida Coastal Everglades Long-Term Ecological Research Program (Grant No. DBI-0620409), the National Science Foundation Doctoral Dissertation Research Improvement Fellowship (Grant No.BCS-1357449) as well as the FIU Morris and Anita Broad Research Fellowship. 


\begin{abstract}
OF THE DISSERTATION
PRODUCING COLLABORATIONS THROUGH COMMUNITY-LEVEL PROCESSES OF CLIMATE CHANGE AND WATER MANAGEMENT PLANNING
\end{abstract}

by

Dumitrita Suzana Mic

Florida International University, 2015

Miami, Florida

\title{
Professor Laura Ogden, Co-Major Professor \\ Professor Gail Hollander, Co-Major Professor
}

While much attention has been given to the ways local communities may be impacted by climate change, this dissertation focuses ethnographically on the local agencies decision-making processes, a less-studied aspect of this topic. The primary purpose of this dissertation research is to understand how government agencies in southern Florida integrate climate change into their decision-making processes while dealing with political resistance. This research expands our understanding on the cultural politics of a new kind of environmental change, where national and international climatechange politics is brought into local water politics to illuminate how new and not so new visions about life in the contemporary metropolis collide and collude.

Using multiple research methods including ethnographic fieldwork, participant observation, semi-structured interviews, and document research, I analyze the activities of the Miami-Dade County Climate Change Advisory Task Force Committee (MDCCCATF or "the Task Force") as well as the water management practices of the regional water management agency, the South Florida Water Management District (SFWMD or 
"the District"). My findings include the following: (1) the Task Force activities have spearheaded Miami's institutional adaptation to climate change; (2) historic legacies complicate water management and climate-change related decision-making processes; (3) a focus on the certainties of climate-change science allows climate change to persist in politically contentious planning contexts.

My dissertation concluded that while planning for potential climate-change impacts can be difficult due to multiple institutional constraints that resource agencies like the District have, scientists and policy-makers have crafted an innovative culture that is particularly visible at sites where science and decision making intersect. 


\section{TABLE OF CONTENTS}

CHAPTER PAGE

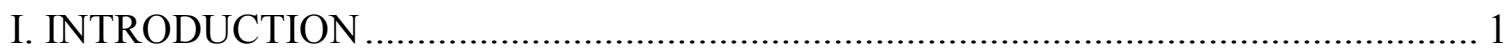

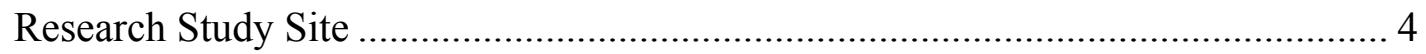

The South Florida Water Management District......................................................... 5

The Miami-Dade County Climate Change Advisory Task Force ………………...... 9

Research Goals and Objectives...................................................................... 16

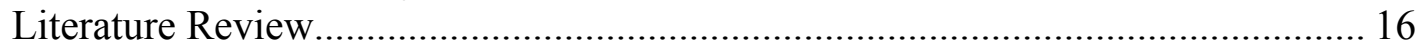

Research Design and Methodologies ................................................................. 23



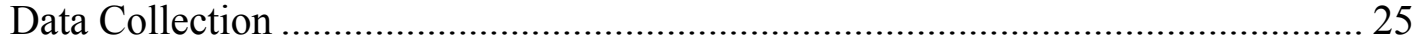

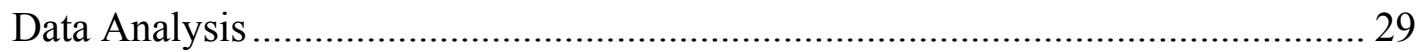

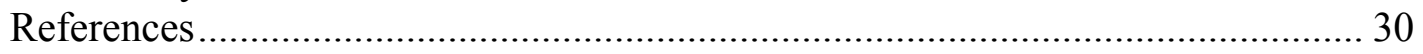

II. URBAN DEVELOPMENT AND CLIMATE CHANGE ADAPTATION …….......... 36

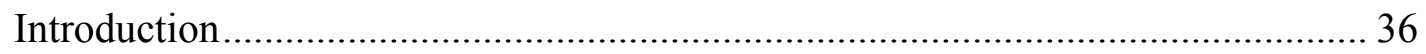

South Florida's Development ........................................................................... 37

Climate Change Vulnerabilities in Miami ........................................................... 44

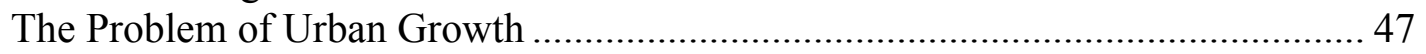

Financial and Social Responsibility ..................................................................... 49

Miami-Dade County Water and Sewer Conundrum................................................. 49

Discussion and Conclusions: Climate Change, not a Financial Risk?..................... 54

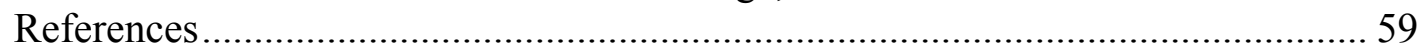

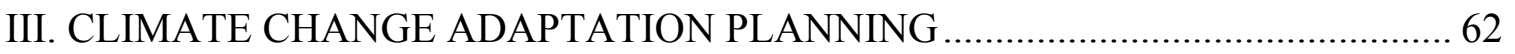

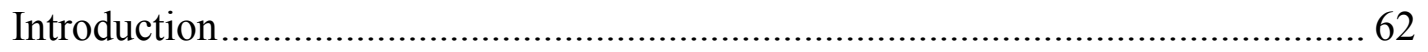

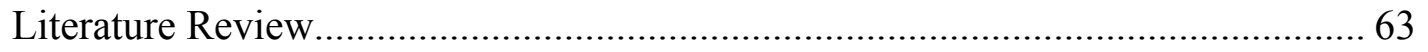

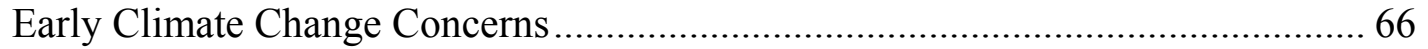

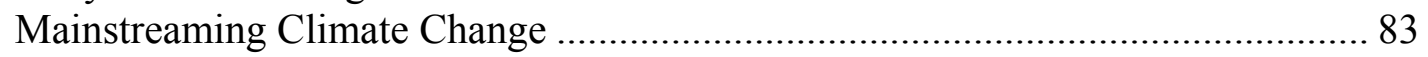

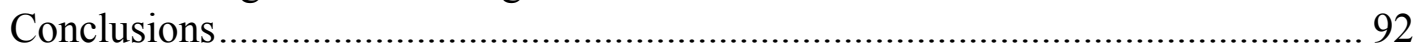

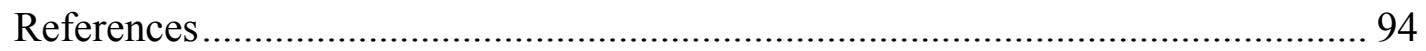

IV. THE SOCIO-ECOLOGICAL HISTORY OF WATER MANAGEMENT ................ 97



Special Interest Groups in South Florida ................................................................ 97

Water Management in South Florida Before 1972 ................................................ 99

The C\&SF Flood Control Project and South Florida's Environmentalism ............ 102

Water Management and the Legacies of the $20^{\text {th }}$ Centuries ………………............ 110

Conclusions and Discussion ............................................................................. 116

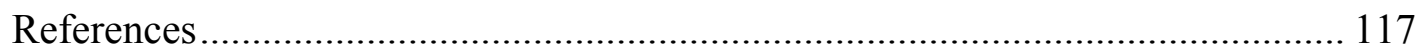

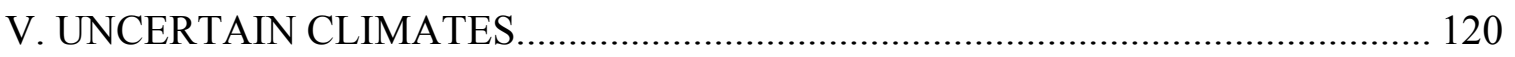

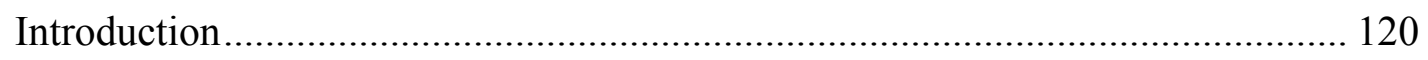

The District's Impossible Mission ....................................................................... 123

Models, Data and Decision Making..................................................................... 130

Legally-Defensible Science and Decision Making …………………..................... 135 


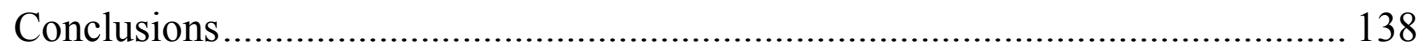



VI. CLIMATE CHANGE AT THE DISTRICT ...................................................... 141

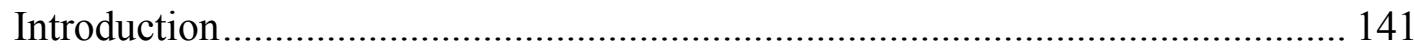

State Politics and Climate Change ................................................................... 143

Collaborations and Climate Change Practice Sites............................................. 147

Climate Change's Enabling Rhetoric............................................................. 149

The Uncomfortable Science and Policy-Making Boundary ................................ 153

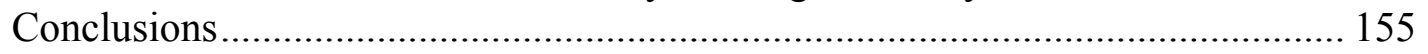

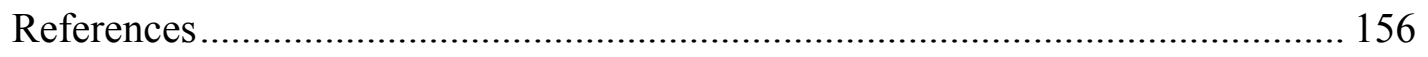

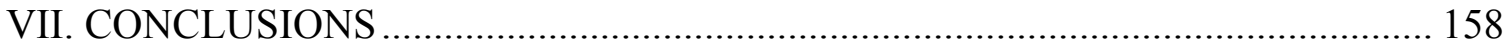

Findings: The Task Force …........................................................................... 159

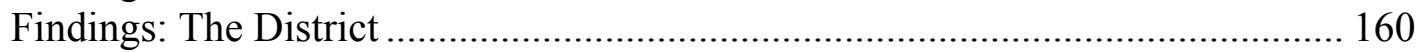



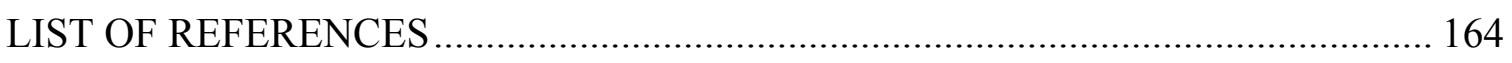

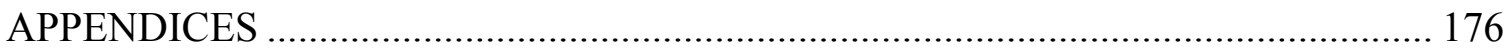

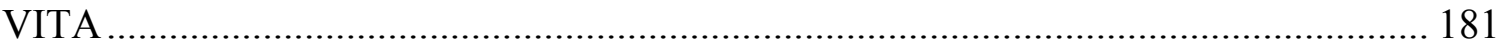




\section{INTRODUCTION}

Large urban areas, such as Miami, can play a fundamental role in shaping today's responses to the global environmental crisis. This role was powerfully exemplified in $1989^{1}$ when, through a set of legislative actions, city officials in Irvine, California, managed to reduce fossil fuel emissions by more than $50 \%$ in one year. ${ }^{2}$ This success came in stark contrast to several failures to negotiate climate-change mitigation strategies through international alliances (Pielke 2007). During the 1990s climate change became increasingly a local-government problem, sometimes due to voluntary action to curb greenhouse gas emissions and create more sustainable economies, as in the case of Irvine. Beginning with the new millennium, attention shifted from mitigation to adaptation as certain communities began to feel several effects of climate change (Crate and Nuttal 2009). Anthropologists have shown how adaptation to climate change is multidimensional, involving changes in beliefs, knowledge, and behavior (Fiske et al. 2014), and place-based (Crate and Nuttal 2009). Current climate change research in anthropology has problematized climate-change adaptation frameworks using a cultural perspective to highlight the complex interaction between climate change, global policy, and people's ability to adapt. This research points to the importance that local institutions could have in the process of informing both global and local approaches to climatechange adaptation (Agrawal 2011). In this dissertation I examine the ways climate change emerged and evolved as a concern within two key, yet very different,

\footnotetext{
${ }^{1}$ In 1989, after being fought in Senate, Irvine's mayor successfully passed a law that phased out the use of all compounds that destroy the stratospheric ozone layer (ICLEI 1995, 4).

${ }^{2}$ A major theme of the Earth Summit Agenda 21, 1992. Rio de Janeiro.
} 
environmental governance entities. I pay particular attention to the practices that enabled the incorporation of climate change into existing planning and management activities as these offer important insights on the ways adaptation is conceptualized, the perceptions on the region's adaptive capacity, socio-political flexibilities, and inflexibilities; in other words, the cultural patterns that define these practices.

Miami is particularly well suited for the study of climate change both due to its administration's early focus on climate-change mitigation and adaptation as well as the complex vulnerabilities to climate change that this region is facing. Miami was one of the first and most important urban areas to take an active role among local governments in the US and around the world in terms of climate change. In 1993 Miami's leaders committed through an alliance with the International Council for Local Environmental Initiatives (or ICLEI-Local Governments for Sustainability) or ICLEI to implement a Long Term Urban Carbon Reduction Plan to mitigate the effects of climate change (Calle and Flagler 1998). ${ }^{3}$ During the two-and-a half decades since climate change was officially a part of Miami's administrative goals, a series of agencies (governmental as well as non-governmental) integrated climate change into their planning and sometimes their practices.

Miami's early involvement in climate-change mitigation and adaptation is likely due to its leaders' awareness that Miami is ground zero in terms of vulnerability to

\footnotetext{
${ }^{3}$ ICLEI is today a global organization connected to the United Nations Environmental Program (UNEP). Its goal is to offer support to local-governments around the globe to achieve more sustainable economies, while restructuring its practices to incorporate both climate-change mitigation and adaptation goals. One of ICLEI's founding members was Miami-Dade County's clerk, Mr. Harvey Ruvin.
} 
climate-change impacts, particularly sea level rise. An early analysis of global climatechange impacts noted that Miami was one of the most vulnerable urban regions in the world in terms of assets exposed to sea level rise-exacerbated flooding (Nicholls et al. 2008). Important areas, like the city of Miami Beach, are already experiencing increased flooding during the rainy season or sometimes even high-tide events ${ }^{4}$. Regional resource management agencies have identified increased vulnerability to salt-water intrusion into freshwater aquifers as well as a need to re-think the urban flood protection system in view of the sea level-rise impacts (Obeysekera et. al 2011; CCATF 2010). In addition, there is evidence that climate change will result in increased evapotranspiration leading to prolonged draughts (Obeysekera et.al 2011, 135).

As I will show in the literature review section, climate-change research in anthropology has tackled many important aspects related to the impacts of climate change. However, the local institutional aspects of climate change have received much less attention. This dissertation fills this research gap through an ethnographic account of the activities of the Miami-Dade County Climate Change Advisory Task Force (CCATF), an advisory body designed to help Miami-Dade County's leaders grapple with the local dimensions of climate-change impacts. The Task Force was created with the sole purpose of understanding the potential implications that climate change could have in South Florida, particularly Miami-Dada County and helping this region's political leaders design ways to meet the challenges that these could pose. The Task Force as an advisory body had a challenging, yet clear task ahead. Water and its management were highlighted

\footnotetext{
${ }^{4}$ Some of the most severe flood impacts from high-tides have been solved or are currently being considered by Miami Beach city officials in an effort to respond to the impacts of sea level rise.
} 
early on as a key climate-change adaptation factor in South Florida. However, as others have noted (Crate and Nuttal 2009) the most difficult climate-change adaptation pressures are experienced at the level of agencies that have other main objectives such as flood control and water distribution. Such agencies have to add to an already complex set of prerogatives the task of planning for the impacts of climate change. I examine this context through an ethnographic study of the South Florida Water Management District (SFWMD), the regional water management agency in South Florida.

\section{Research Study Site}

As I mentioned earlier, this dissertation focuses on the study of two governance entities. These entities are a part of Southeastern Florida, a region that corresponds largely to the historic Everglades ecosystem. Throughout the years, and particularly during the $20^{\text {th }}$ century, a series of water management practices have allowed this region to develop into a complex socio-ecological system. There are three major land-use categories that define Southeast Florida's landscape: agricultural, largely represented by the Everglades Agricultural Area south of Lake Okeechobee; the conservation area, which includes the Everglades National Park as well as a series of other protected lands; and the coastal conurbation, known as the Greater Miami Region. Two watersheds dominate the region: the Kissimmee-Okeechobee watershed and the Big Cypress watershed. The existence and sustainability of this region has been and continues to be largely dependent on the ways these two watersheds are managed. Directly and indirectly linked to the regions economy, water management practices have been at the center of the regional as well as state politics. Today climate change threatens the ability of the region 
to respond effectively to flooding events or to secure the health of the Biscayne Aquifer, the region's main source of freshwater.

I chose the South Florida Water Management District (the "District" hereafter) as the site of my ethnographic fieldwork due to the importance that water management plays in the region's ability to adapt to climate change. However, in order to understand the ways in which climate change emerged and evolved as a concern in the region, I dedicated part of this research to the study of the Miami-Dade County Climate Change Advisory Task Force (the "Task Force" hereafter). In contrast to the District, a state water-management agency with a long history, the Task Force was a temporary advisory body established in 2006 to help Miami-Dade County's Commissioners grapple with emerging climate-change science both in terms of impacts as well as in terms of possible solutions. In the following pages I describe these two research sites to contextualize the cultural, ecological, and political complexity that shapes current approaches to climatechange adaptation in South Florida.

\section{The South Florida Water Management District}

Several studies show how South Florida's socio-ecological history is synonymous to its water management history and point to the important role that the District has played in this history, particularly since the last half of the $20^{\text {th }}$ century ${ }^{5}$ (Blake 1980; Carter 1974; Godfrey and Catton 2011; Grundwald 2006; Hollander 2008; McCally1999;

\footnotetext{
${ }^{5}$ Even though the South Florida Water Management District was created officially in 1977 (Godfrey and Catton 2011, 95), its institutional roots go back to the 1930s and 1940s when SFWMD's predecessor, the Flood Control District (FCD), entered into a rather unique partnership with the federal government to build one of the largest flood control system of those times the Central and South Florida Flood Control Project (the C\&SF). The FDC expanded its goals in the 1970s and was renamed as the SFWMD.
} 
Ogden 2008; 2011;Villeisis 1997). As scientists and water managers at the District grapple with difficult questions related to the extent, timing, and parameters of climatechange impacts in the various sectors of regional water management, they do so in the context of this agency's numerous other water management responsibilities, historical legacies, and shifting state politics. In what follows I will present this rich institutional context as it emerges in several important studies.

\section{Historical Legacies: Diverse and Sometimes Conflicting Objectives}

Water management in South Florida was shaped initially by a few crises. Godfrey and Catton (2011) offer one of the latest and most complete historical accounts on water management in South Florida. Notably, the early $20^{\text {th }}$ century tropical storms, which resulted in important economic and human losses, produced a socio-political environment that institutionalized a unique state-federal water management. Its most visible imprint into the material world of South Florida was the almost two-decade-long project that reimagined South Florida's geo-hydrology and transformed the historic Everglades from a swamp into today's multi-purpose land. Even though drainage projects had been a part

of South Florida's $19^{\text {th }}$ century development, the middle of the $20^{\text {th }}$ century project, known as the Central and South Florida Flood Control Project (the C\&SF), resulted in irreversible geo-hydrologic transformations. In the 1960's, when this project was completed, water management was largely the responsibility of the Flood Control District (FCD), a state agency that worked together with the US Army Corps of Engineers. The $\mathrm{C} \&$ SF project effectively tackled the region's flood control problem. However, at the end of this project, some of South Florida's citizens and scientists were arguing that the project had perpetuated and in some cases augmented a series of ecological imbalances, 
and led to water shortages due to pollution and water diversions (Blake 1980). These concerns became a part of an important environmental movement that culminated with the establishment of a few key legislative actions, such as the 1972 Florida Environmental Land and Water management Act, the Water Resources Act, the land Conservation Act as well as the Florida Comprehensive Act (Godfrey and Catton 2011, 95). While these legislative acts ushered a more environmentally sustainable water management framework, they also transformed the region's institutional composition. More precisely, many of the local land and water regulations became subject to state approval and the District became central to much of this regulatory environment. ${ }^{6}$ The C\&SF Flood Control project and the 1970s environmental reforms shaped many of the newly established District practices. More precisely, the District took on the task of managing the C\&SF project, an inheritance from the previous state agency, the Flood Control District, as well as the obligation to manage water in ways that did not damage the environment (Godfrey and Catton 2011, 96). Many of the scientists I interviewed at the District began their careers there during this period as the agency expanded its employee base through the creation of an environmental sciences division. The scientists working within this division had to conduct research to understand the environmental impacts that the C\&SF project had had in the region, particularly in relation to the conserved Everglades lands.

Researchers showed that the Everglades' ecological problems are, in fact, a water management problem. As a result, in 2000 the District was tasked with implementing the

\footnotetext{
${ }^{6}$ According to Godfrey and Catton (2011), the Water Resources Act established the five regional water management districts in 1972 .
} 
Comprehensive Everglades Restoration Project (the CERP). ${ }^{7}$ The project's main goal is to restore the south Florida ecosystem while providing for other water resource needs. More precisely, the project, having more than 60 components, promises to improve quality, quantity, timing, and distribution of water deliveries to the environment as well as to protect the region's aquifers from pollution and increase the quality and quantity of water supplies for agricultural and urban users. With a starting budget of $\$ 10.5$ billion and a 35 yearlong implementation timeframe, the CERP is the largest hydrologic restoration project ever undertaken in the United States (NRC 2006). CERP's multiple objectives are meant to reduce some of the water management problems identified since the 1970s when enforcing and implementing water quality standards became a part of its mission.

Today the District is one of the largest water management agencies in the world both in terms of the size of population and area it has under its jurisdiction as well as in terms of the complexity if its mission. Managing 16 counties $^{8}$ with a population of approximately 8.1 million people (SFWMD 2013, 3), the District's boundaries correspond largely to the above-described Southeast Florida boundaries, a total area of 17, 930 square miles (SFWMD 2013, 3). Some of the operation and maintenance activities of this water management agency include the oversight of over 4769 miles of canals and levees, the management of 667 water control structures and 722 smaller culverts, 67 water pumps which send water south towards the Everglades National Park

\footnotetext{
${ }^{7}$ Through the 2000 Water Resource Act Title VI, Section 601

${ }^{8}$ The 16 counties are: Broward, Hendry, Miami-Dade, Okeechobee, Charlotte, Highlands, Monroe, Palm-Beach, Collier, Lee, Orange, Polk, Glades, Martin, Osceola, and St. Lucie.
} 
as well as to the east and west coasts of the peninsula. In addition, the District regulates residential and commercial developments and in the 1990s, the District began monitoring and regulating nutrient loads in the region's waters. The District also provides the consumptive water permits for the region's water users (SFWMD 2012, 5).

As the District's missions multiplied throughout the years so did its revenue. Largely financed through ad-valorem taxes on properties, the District's budgets were very generous. Many of my interviewees noted that this abundance was reflected in the size and abilities the agency had to conduct research and hire some of the most respected scientists in the country. However, the recent economic crisis directly affected the agency's annual revenues as many property owners could not afford to pay their real estate taxes. In addition, the ad-valorem tax-based funding was modified through legislative action and further diminished the agency's funding sources. The agency had to simplify its activities to focus only on its crucial missions. While research and innovation had been one of the identifying characteristics of this agency prior to this crisis, after 2010 research activities became increasingly scrutinized and viewed as unnecessary expenditures.

My ethnographic research examines how climate change became and evolved as a concern during one of the most difficult periods in this agency's history while paying attention to the ways in which its need to balance multiple and conflictive missions in a changing organizational and political context shapes the agency's responses.

\section{The Miami-Dade County Climate Change Advisory Task Force}

In this section I focus on describing the Task Force in terms of its mission and membership as well as its place within the county bureaucracy. It is important to 
understand the formative aspects of the Task Force as these shapes the ways in which climate-change adaptation was conceptualized.

\section{The Task Force and Miami-Dade County's Bureaucracy}

Miami-Dade County is the largest bureaucracy in the state and among the largest in the nation. The Miami-Dade County administration is the largest employers in the region, employing approximately 82, 000 workers (MBC 2013). The Task Force was created through an ordinance put forward by the Board of County Commissioners (BCC) that represents 13 districts within the county. The Board of County Commissioners shapes the direction and content that the county's socio-economic life takes. The BCC can enact legislation, create departments, regulate businesses operating within the county, and, with a two-thirds majority vote, it can overturn the mayor's veto.

The Board of County Commissioners was, therefore, not only responsible for creating the Miami-Dade Climate Change Advisory Task Force but also for shaping its mission, providing financial and other needed resource and deciding on the extent of its authority. In addition, the BCC is unique in its ability to decide on the degree to which the Task Force recommendations would become a part of the county's mainstream activities, mainly through its legislative power.

\section{$\underline{\text { Creation }}$}

The adoption of the ordinance that created the Task Force was a result of the vision and astuteness of Miami-Dade County’s Clerk of Courts, Harvey Ruvin. Much of Ruvin's career had been spent serving various environmental causes. In 1990, Ruvin was involved in the first-ever international effort to coordinate local governments' environmental initiatives, the United Nations World Congress for a Sustainable Future, 
where he represented all US counties. Particularly telling is the fact that in the early 1990, Harvey Ruvin was one of the founding members of ICLEI, an organization that counts more than 1000 worldwide local governments as its members. ICLEI mission is to provide its members with tools to find ways to combat today's environmental crises in sustainable ways. ICLEI is the only organization chosen to represent the UN in all local government at all United Nations' meetings dealing with the environment and sustainability. Today, Ruvin is also the vice-chair of this organization and its US president. Locally, Ruvin made efforts to make climate change a part of the county's priorities. In 1993 he was instrumental in making Miami-Dade County one of the first US members of ICLEI and began work on a climate change mitigation project. Therefore, in 2006, when the ordinance text that would create the Task Force was submitted to vote, climate change had already been a part of the Miami-Dade County's administration planning vocabulary. The notes taken during the July 18, 2006 Board of County Commissioner's meeting, when ordinance $06-113$ was adopted into law, point to the importance that Ruvin's work had in establishing the Task Force, "Commissioner Seijas noted she worked with County Clerk Harvey Ruvin for several months on the foregoing resolution and acknowledged the threat of global warming." 9

However, if Harvey Ruvin's international and local work on climate change was impressive and legitimated the County Commissioners' decision to support the creation of the Task Force, it is safe to assume that his long and extremely successful career within the county's bureaucracy was equally important. The fact that Ruvin had worked

\footnotetext{
${ }^{9}$ Miami -Dade County Legislative Item File Number: 061152 http://www.miamidade.gov/govaction/matter.asp?matter $=061152 \&$ file $=$ true $\&$ yearFolder $=\underline{=} 2006$ (last retrieved on January 18, 2015)
} 
with one of the County commissioners for several months to formulate the text of the proposed ordinance attests to the ease with which he was able to summon a commissioner's attention. This is likely due to his insider's knowledge of the way the commission worked, as he had been a county commissioner for twenty years, from 1972 to $1992 .^{10}$

\section{$\underline{\text { Mission }}$}

My research on the work of the Task Force shows that current understandings on the role, design, and practices of advisory bodies are much more complex than currently defined by official bureaucratic documentation. More precisely, advisory bodies are not simply designed to gather, discuss, and provide advice to the administrative bodies they serve. Jasanoff (1990) has shown in her work that advisory bodies operate through a complex web of socio-political relations. Nevertheless, she argued, advisory bodies can be broadly categorized as either technocratic or democratic. Technocratic advisory bodies demand more expert involvement in decision-making processes and are often criticized for being less transparent and inclined to cater to special interests. In contrast, democratic types are more open to public input, and are usually formed by representatives from different interest groups. These bodies can be more contentious as they lack strong expert-based legitimizing power. Jasanoff’s study of advisory bodies referred mainly to federal regulatory bodies which often have a long history and are a permanent part of the regulatory branch of the US government. The Task Force was designed as a temporary entity that focused solely on the issue of climate change. The ordinance that established

\footnotetext{
${ }^{10}$ According to Ruvin's official bio-sketch, this had been the longest appointment in the history of the board.
} 
this entity (06-113) noted that the purpose of this task force was to "provide technical assistance and advice to the Board of County Commissioners as to mitigation and adaptation measures to respond to global warming climate change" (Ordinance 06-113, Section 1(a); page 4). According to this definition, the Task Force could be categorized as a technocratic advisory body.

\section{Membership}

However, an analysis of the Task Force's membership shows that its members were a mix of scientists, community activists, and employees of the local administration. The ordinance established three major categories of Task Force memberships: members appointed by one of the County Commissioners (a total of 13), nine members selected by the County Manager to represent government agencies and educational institutions that would provide necessary technical expertise in the various branches of the county's administration, as well as two appointments made by the county mayor. In addition the county commissioners appointed county clerk Harvey Ruvin as the Task Force chair given his continuous work on climate-change mitigation, planning, and implementation. The ordinance notes that the county commissioners, mayor, and county-manager should appoint members who have a reputation for "integrity and community service and have demonstrated an interest in a field or activity related to global warming climate change" (Ordinance 06-113, Section 2(a); p.4). A “demonstrated interest” does not necessarily mean scientific expertise in climate change.

Indeed, at the time of its first meeting, the Task Force was made up of 24 appointed members, including its chairman. Based on the member's affiliation, the Task Force has three major membership categories. According to the affiliations declared by 
the Task Force members there were nine members who declared affiliation with a business, seven members affiliated with a local university, and six members who had positions within the county or state bureaucracy. Two members do not fit these broad categories; namely, a member affiliated with the Everglades Defense Council and a member who did not declare any affiliation but was well known among local and state administrators for his active role in state environmental politics. For a complete list of the declared Task Force appointed members see Table 1.

Even though these broad membership categories offer some insights into the types of expertise and interests that formed the core of the Task Force, many of the above affiliations do not describe the often multiple roles that Task Force members had. In addition, while some of the initially appointed members resigned or were less involved in the Task Force activities and meetings, the Task Force memberships expanded and further diversified throughout the four years of its activities. It is safe to say, therefore, that the Miami-Dade County Climate Change Advisory Task Force fits broadly in the democratic category of advisory bodies that Jasanoff (1990) described in her work.

\section{$\underline{\text { Responsibilities and Authority }}$}

As I mentioned before, Ordinance 06-113 defined the Task Force's responsibilities in terms of a technical advisory body. However, there is clear evidence that the Task Force was envisioned in broader ways. More precisely, one of the commissioners asked that for the Task Force's mission to be expanded to include a focus on continuing and implementing recommendations that could be derived based on the previous decade's work on climate-change adaptation in the County. While the request 
was rejected at that time, the Task Force dedicated an important portion of its work to discuss and design climate-change mitigation recommendations.

Table 1: Affiliations of the Initially Appointed Task Force Members Data Source: CCATF. 2008. Second Report and Initial Recommendations.

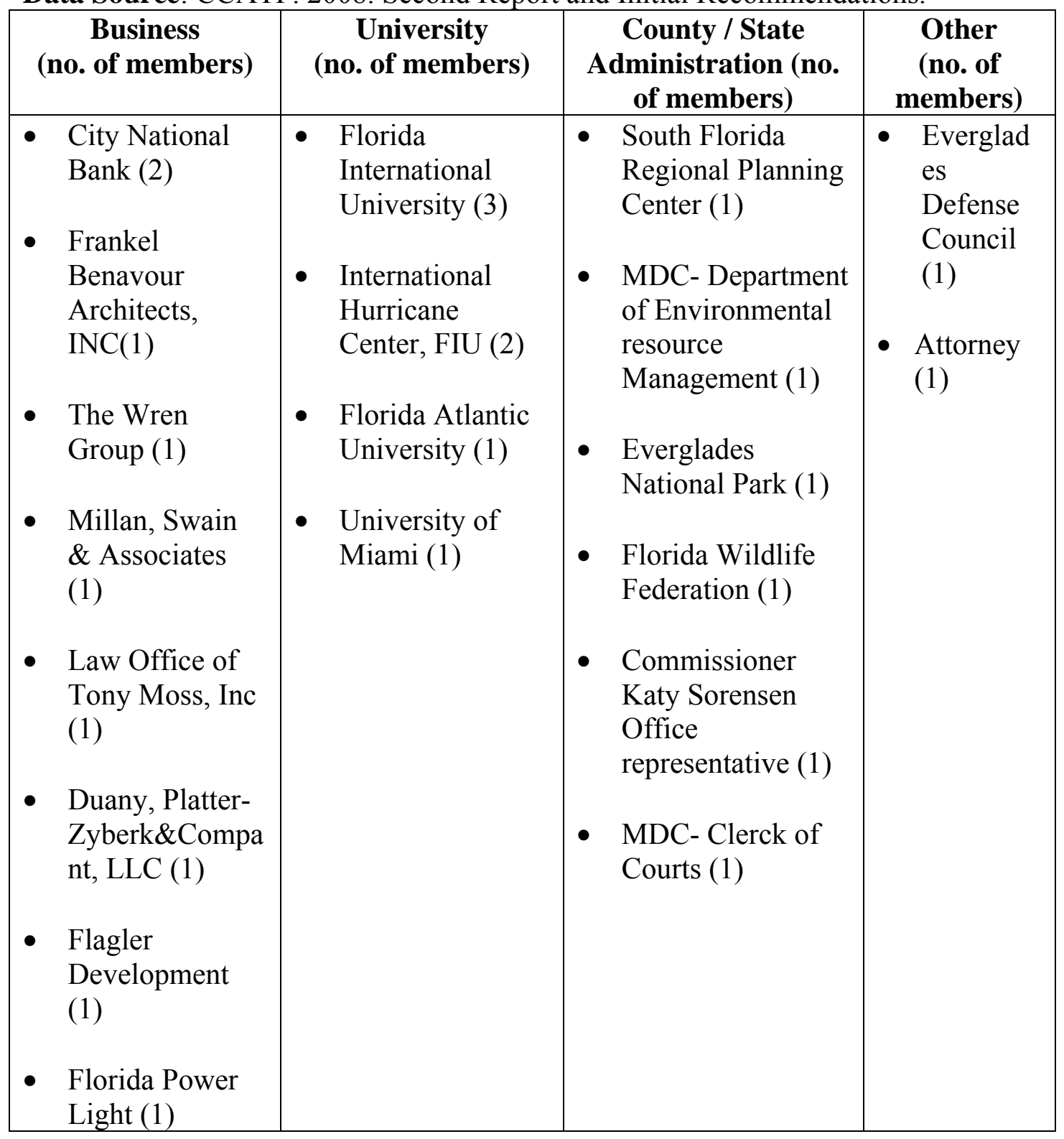

My analysis of the Task Force meeting minutes and audio recordings shows that during the five years of its existence (2006-2011), it attempted to expand on its preestablished mission. In Chapter 3 of this dissertation, I discuss the ways the Task Force, 
while limited in its ability to implement climate-change adaptation, used consensus and alliance building to incorporate climate change into the work and concerns of the county's various departments.

In my introduction's following sections I provide an overview of my research goals and objectives, study site, relevant literature and research methodology. First, I detail my dissertation's research goals and objectives, outlining my project's guiding research questions. Next, I discuss the anthropological literature that informs my dissertation. I then explain my research approach and research methodology.

\section{Research Goals and Objectives}

The primary goal of my dissertation research was to investigate the ways in which agencies integrate climate-change concerns within their principles and practices. I pay particular attention to the ways climate change is channeled through the institutional contexts of Miami's county administration and South Florida's regional water management agency. My dissertation documents how climate change has been incorporated into the county and regional administrative tasks, the practices that enable the integration of climate-change concerns with existing water management missions, and the ways in which formal politics shape this nexus.

\section{Literature Review}

Much current anthropological research on climate change has taken a place-based approach to studying the complex impacts that climate change has on various communities. This literature also discusses the ethical problems that climate change rises when impacts on local communities are discussed within global economic and political contexts. Anthropologists have also built on science and technology studies to draw 
attention to the hegemonic role that western science plays within climate- change policymaking contexts. Anthropological literature has focused to a much lesser extent on the actual processes of planning and policy-making within local institutions that have to incorporate climate change with other existing concerns. In the US this process is often contentious as climate change remains politically controversial. In the following pages I present the anthropological literature on climate change and discuss the way my dissertation contributes to this literature.

\section{Climate Change Impacts on Indigenous Communities}

Anthropological research suggests that the ways different societies understand and experience climate change is at the core of what it means to be human, particularly the way we anchor our lives in the rhythms of what constitutes a place (Hildergard et al. 2012). Drastic changes in the environment can be extremely destabilizing. For example, the environmental change that the Porgean people of Papua New Guinea, experience has led to a breakdown in their belief system (Jacka 2009). Similarly, climate changes are affecting the ability of the Saska people of Northen Siberia to "read" the weather (Cutter 2009). These changes are perceived as being closely connected to the larger changes produced by industrialization in the former Soviet Union. Much research in anthropology shows that the climate change impacts are not merely material, but that climate change has profound cultural implications that can affect the cohesiveness of a society. The disintegration of a society leads to further vulnerabilities that decrease a society's ability to respond adaptively to potential impacts from climate change. Colombi's research, for example, explores the implications that climate change has for the Nez Perce people of the Colombia Basin. The Nez Perce people use water and fish, particularly salmon, in a 
variety of daily life activities as well as during ceremonies like births, funerals, weddings, name-giving ceremonies, pow-wows, and many others. But more than being a part of the Nez Perce's material practices, water and fish are a part of the Nez Perce cosmology. The availability of salmon and water is a symbol of "the Creator's" gift to the Nez Perce. The Nez Perce view the abundance of water ad fish as a sign that their existence is protected and viewed favorably (188). Besides being used in healing ceremonies, water and water flows are rich with cosmological symbolism. The eddies and confluences of a river are perceived as the homes of spirits and form an important part of the Nez Perce creationist stories. The Nez Perce believe that salmon brings the energy of the ocean's energy inland to the plants, animals, and people. These beliefs and practices are at the center of the Nez Perce community cohesiveness. While century old economic activities have already disturbed and negatively impacted their traditional ways of living, climate change is expected to diminish both the availability of water as well as the availability and biodiversity of salmon (Batin et al. 2007 in Benedict 2009, 189).

Several researchers have focused on the impacts that climate change has on the Inuit people of Shishmaref and Kivalina, Alaska (Marino 2012; Marino and Ribot 2012; Shearer 2012). This research discusses the various impacts ranging from loss of protection from winter storms to loss of hunting grounds and destruction of housing (Shearer 2012; Marino 2012). As these communities are forced to relocate, their social cohesiveness is weakened and with it their ability to respond to adverse events. This situation is even more problematic as the Inuit struggle with global and national political representation (Marino 2012). 
Some case studies argue the unprecedented magnitude of the impacts of climate change is overwhelming for communities that have showed a high-degree of adaptability to environmental changes in the past. Such is the case of the Quechua people living in the Peruvian Andes, who began re-integrating certain Inca practices to respond to the decreased availability of water resulting from the increased ice-cap melt. However, as temperatures rise due to climate changes, the water cycle in the Peruvian Andes that now is supplied through the seasonal ice cap melts is expected to be interrupted and result in a complete loss of the ice caps (Bolin 2009). Similarly known to be highly adaptive, the San of Botswana face extreme poverty due the impacts increases in temperature have on their subsistence practices (Hitchcock 2009).

\section{Climate-Change and the Global - Local Relation}

Susan Crate's research on the adaptive practices of the indigenous people of Russia shows that their current adaptation strategies are undermined by ongoing national and global practices of economic change (Crate 2008). This and other research (see Galvin 2007) show how the global and local interact to create multiple dimensions of climate change vulnerability.

Given the magnitude, complexity, and diversity of climate-change impacts, anthropological research has also focused on unpacking some of the ways global frames of climate-change adaptation conceptualize these local impacts and how these conceptualizations might impact adaptation processes locally. This type of inquiry has highlighted the fact that western scientific constructions of climate knowledge dominate the way climate change is dealt with, while other forms of knowledge are considered 
unscientific and thus irrelevant in climate-change adaptation planning contexts (Hastrup 2012; Verweij et al. 2006).

For example, Marino and Schweitzer's (2009) research with the Innupiaq villages of Northwestern Alaska shows that much inquiry on the perceptions of that climatechange impacts have on these peoples has not been informed by their language and culture. While the Innupiaq incorporated western scientific concepts of climate change in their vocabulary, they did not relate their complex daily and seasonal experiences of climate change with existing western concepts of climate change. In exchange, when researchers avoided using western scientific concepts of climate change the Innupiaq were able to paint a much richer account on the impacts of climate change. Because nonwestern climate-change knowledge fails to be integrated within global adaptation strategies many of the devastating consequences of climate change remain unacknowledged.

Other research (Oliver-Smith 2010) points to the relation between climate- change impacts and migration. He argues that climate-change refugees do not receive proper international support because of existing immigration laws. Many of the world climatechange refugees are often categorized as economic refugees and are refused relocation. Because the current global bureaucracy is not designed to incorporate diverse perspectives on climate-change impacts, anthropological research calls for alternative approaches to global models of adaptation (Lipset 2013).

\section{Expertise and Adaptation}

The $5^{\text {th }}$ IPCC report (2014) defines adaptation as a sum of processes of adjustments to climate change with the goal of moderating harm or exploiting beneficial 
aspects (2). Anthropological research argues that adaptation involves first and foremost changes in the beliefs and behaviors that address unsustainability and aim at improving living conditions (Fiske 2014). IPCC's conceptual frame has been criticized for its resulting focus on technical and infrastructural strategies (Thornton and Manasfi 2010). Expert-led decision making is often criticized as a narrow tool for addressing the socio-historical processes that carry on past vulnerabilities and create new ones often in the form of technological disasters (Davis 2006; Lankao 2011). This research also argues that scientific expertise is called upon to alleviate the effects of earlier applications of science (Davis 2006), making our modern environment increasingly dependent on a series of technologies of knowledge, such as risk assessment (Beck 1992). However, these technologies are often limiting, infusing planning strategies with some "tacit beliefs about determinacy, prediction and rational control" (Demeritt 2001, 312). Moreover, Jasanoff (2007) argues that oftentimes these technologies overstate the known, understate the unknown, and focus on the short term.

The critique of experts and expertise has influenced much anthropological inquiry (see Harraway 2004; Latour 1992). Some of this research discusses scientific expertise in the larger context of modernity (Latour 1992), arguing that modern state institutions have reached a crisis of categorization. The distinction between nature (or scientific facts) and culture (social facts) is hard to make in an increasingly complex world, and therefore research as well as management should account for all these complex interactions. In light of this critique, researchers have noticed, more recently, a loss of trust in experts and science. 


\section{Climate Change Adaptation and the Role of Institutions}

Some research has showed that much climate-change adaptation planning is focused on the technical/infrastructural aspects without addressing the cultural aspects of climate change (Crate and Nuttall 2009; Botiren 2009) or the systemic causes of vulnerability to climate change (Orlove 2009). In addition, adaptation frameworks that do not aim at changing the beliefs, interests, practices that have created vulnerability to climate change are, in fact, designed to perpetuate conditions of vulnerability (O'Brien 2012).

Finally, the critique on current frameworks for climate-change adaptation argues that while adaptation if often defined within a global policy-making context, it is the local institutions that are key in the process of producing positive adaptation results (Agrawal 2011). This is largely because various local resource management agencies are tasked with designing fitting adaptation measures and integrating them with existing institutional arrangements (Grothmann 2011). Research shows, however, that for many societies the ability to respond to climate change proactively is severely constrained by institutional and legal barriers (Crate and Nuttall 2009). Few et al. (2007) argue that the major impediment to adaptation does not necessarily have to do with a lack of capability to adapt but rather with an unwillingness to pay the social costs of adaptation. In addition, some argue that a sense of urgency has not been perpetuated throughout the social system, and therefore, there is some lack of interest in pursuing adaptation measure (Adger et al. 2005).

Using a cultural lens, my research contributes to current inquiries into the institutional aspects of climate-change planning, a less addressed climate-change topic. 
As I will show in the second chapter of this dissertation, the prospect of climate-change impacts and the need for adaptation measures come in direct contrast with current struggles to maintain a certain urban economic vibrancy or at the very least to avoid market crashes like the ones experienced in the US in 2007. In this context, adaptation is indeed viewed as a high cost to pay and it is met with a certain opposition. Yet, as I show in chapter three, unwillingness or a lack or urgency does not necessarily describe Southeast Florida's climate-change adaptation-planning context.

\section{Research Design and Methodologies}

\section{Research Overview}

My research consists of two components which are used to produce an analysis of the climate-change adaptation planning culture in Miami: ethnographic methods to understand the practices of water management at the largest water management agency in the region, the South Florida Water Management District, as well as an ethnography of the first local climate change advisory body in the United States, the Miami-Dade County Climate Change Advisory Task Force. I used these methods to investigate how different agencies and actors involved in environmental planning and decision making perceive and experience climate change as a political phenomenon. I define the political as the space of policy-making where the struggle over the content and direction of the socioecological life takes place (Swyngedouw 2010).

My dissertation entailed approximately 12 months of data collection. I drew upon multiple methods and data sources, including participant-observation, semi-structured interviews; and document and archival research. Table 2 below provides a complete overview of these methods. 
Table 2: Research Overview

\begin{tabular}{|c|c|c|}
\hline Study Site & Research Methods & Research Analysis \\
\hline $\begin{array}{l}\text { The Task } \\
\text { Force (MDC- } \\
\text { CCATF) }\end{array}$ & $\begin{array}{l}20 \text { Task Force meeting minutes and } 20 \\
\text { corresponding audio recordings; } \\
10 \text { newspaper articles that discuss climate } \\
\text { change locally between } 2013 \text { and } 2014 \text {; } \\
\text { Participant observation at more than twenty } \\
\text { climate-change workshops, and related } \\
\text { events (see Appendices for complete list); } \\
3 \text { formal interviews with former Task Force } \\
\text { members; } \\
\text { Document Research of Miami-Dade County } \\
\text { climate change/planning publications }\end{array}$ & $\begin{array}{l}\text { Concept mapping (Berg 2007) } \\
\text { (point 1); } \\
\text { Inductive (open) and deductive } \\
\text { coding (Ryan and Bernard 2003) } \\
\text { (points } 1 \text { and 4); } \\
\text { Timeline of key events (Bernard } \\
\text { 2006) (point 1); } \\
\text { Analytic Notes (Corbin and Strauss } \\
\text { 2008) (point 3); } \\
\text { Constant comparison (Glaser and } \\
\text { Strauss 1967) (point } 2 \text { and 5); }\end{array}$ \\
\hline $\begin{array}{l}\text { The District } \\
\text { (SFWMD) }\end{array}$ & $\begin{array}{l}10 \text { formal, open-ended interviews; } \\
1 \text { open-ended interview with Miami-Beach } \\
\text { city official; } \\
1 \text { open-ended interview with a MDCWSD } \\
\text { private contractor } \\
\text { Participant observation at the District's } \\
\text { Governing Board public meetings ( } 6 \text { total); } \\
\text { District participant observation (April 2014 } \\
\text { to February 2015); } \\
\text { Participant Observation at the District's } \\
\text { public meetings (6 Water Resources } \\
\text { Advisory Committee (WRAC) meetings); } \\
\text { Document research } \\
\text { WRAC meeting minutes research } \\
\text { Sun-Sentinel archival research (2006 - 2012) }\end{array}$ & $\begin{array}{l}\text { Inductive (open) and deductive } \\
\text { coding (Ryan and Bernard 2003, } \\
\text { Corbin and Strauss 2008) (points } 1 \text {, } \\
\text { 2, } 3 \text { and 4); } \\
\text { Analytic Notes (Corbin and Strauss } \\
\text { 2008) (points } 5 \text { and 6); } \\
\text { Constant comparison (Glaser and } \\
\text { Strauss 1967); } \\
\text { Timeline of key events (Bernard } \\
\text { 2006); Inductive (open) and } \\
\text { deductive coding (Ryan and Bernard } \\
\text { 2003) (point 7) }\end{array}$ \\
\hline
\end{tabular}

\section{Research Strategies}

My entrance into the field of climate change and water management planning was facilitated by my work as a research assistant first for the Institute for Public Opinion Research (IPOR) at Florida International University, and second, as a research assistant 
for the NSF-funded Miami Urban Long Term Research Area (ULTRA) exploratory award. In both of these capacities I attended several meetings related to climate change in Miami beginning with the summer of 2010. These meetings served as primary sites for climate-change planning, employing a vast array of scientific and administrative expertise. In addition, I organized a workshop entitled "Water in a Changing Climate," which brought together key climate local scientists and water managers to formulate research objectives. In preparation for this workshop, I have interviewed staff members from Miami Dade Water and Sewer, the Florida Department of Environmental Protection, and the South Florida Water Management District. In doing so, I established important contacts that helped me further identify research participants. As I began my fieldwork in January 2014, I called on these contacts to discuss my research objectives and ask for guidance and references that would help me collect my data. I now turn to discussing the specific ways I used multiple research methods to systematically collect data to answer my research questions.

\section{Data Collection}

Research Site 1: The Miami - Dade County Climate Change Advisory Task Force (the "Task Force" hereafter)

A part of my research design, I conducted an ethnography of the Task Force. I used the audio recordings as well as all the associated documentation for all the meetings (which I obtained through official requests at the County's Government Center) to understand the complex relations that contributed to Miami's international fame as model for climate-change planning. This work was fundamental to my ability to further examine water management practices and their relation to climate-change politics as well as to 
interview some of the former members of the Task Force. The Task Force was created under the 06-113 Miami-Dade County ordinance of July 2006. Its official purpose was to provide "technical assistance and advice to the Board of County Commissioners as to mitigation and adaptation measures to respond to global warming climate change" (Minutes; February 23 2007; Exhibit 1; Ordinance 06-113, page 1).

The Task Force met from January 2007 to December 2010 sixty-five times. The meeting minutes, however, were taken only for those meetings that convened all the members (known as the main committee meetings) as well as several of the leadership meetings (known as the Steering Committee Meetings); only the first meetings of the subcommittees were recorded. The Task Force met eleven times during the main meetings and recorded ten of these meetings (the first meeting was not recorded). In addition the Task Force created four thematic subcommittees that met separately to discus adaptation and mitigation. Of these meetings I was told that only the first couple of meeting were recorded. Out of these I have obtained the first two audio recordings for the Built Environmental Committee and their corresponding meeting minutes, the first meeting of the Economic and Social Health Committee and the corresponding meeting minutes, the first meeting of the Greenhouse Gas Committee, and its audio recording. Finally, the Task Force organized a Science Committee that often met at University of Miami. Among the exhibits attached to some of the main Task Force meetings I identified a report that includes some important topics discussed during the Science Committee meetings.

In addition I have conducted three formal interviews with former Task Force members. I also interviewed a Miami Beach City official, and a Miami-Dade County 
Water and Sewer Department private contractor. I identified my research subjects after participating in different public meetings. All of my subjects had a public role in at least one of these meetings, either as a recognized speaker or as a member of the public during the public comment period.

\section{Research Site 2: The South Florida Water Management District}

I used a mix of ethnographic methods that included participant observation and semi-structured interviews to capture the multiple ways in which water managers perform their expertise and discuss climate change in relation to their work. I carried out ethnographic fieldwork with water mangers in South Florida. I began this work in July 2013 , by attending the monthly public meetings of the Governing Board (GB) ${ }^{11}$ and the Water Resource advisory Committee (WRAC) held at the District headquarters in West Palm Beach. While some of these meetings are regular planning forums with public input, such as the monthly board meetings, there are a variety of other events in the form of workshops that are limited in their attendance to scientists and water managers that are affiliated to the state or county bureaucracy. In other words, even though under Florida's statutes, these meetings are opened to public participation, these are rarely advertised to outsiders. As Weaver (2008) notes, experts and policy-makers are understudied partly because gaining access beyond their public duties is usually difficult.

Gaining access to the world of scientists and policy-makers at the District was surprisingly easy. Working as a volunteer at the District allowed me to gain a better sense of the ways in which this agency works. The agency has developed an important

\footnotetext{
${ }^{11}$ Although held at the District's headquarters, the Governing Board meetings are not a proxy for the District's work; instead these are the sites where the District administration, its policy-makers, scientists and staff interact with state appointees.
} 
commitment to working with its public; information sessions, events and an abundance of brochures and other materials are easily available in print and on their website. But perhaps, the ease and openness with which I was allowed to learn about this agency is the most important proof of this agency's commitment to transparency. Even though I was not familiar with many of the disciplines that shape the agency's personnel I appreciated the active engagement that scientists and water managers have with research. This is clearly an agency that allows its employees a certain degree of freedom to pursue some of the water management problem in self-directed/ creative ways. In several instances I noticed people staying after the official work hours to continue work. Indeed, my interviews show that District employees, despite certain constrains, have a real appreciation for the people, work environment and the applied research they are able to participate in.

To further answer the questions this research asks, I conducted ten formal, digitally recorded interviews with experts working or associated with District work. I have also discussed extensively various topics related to my research with other District employees who preferred not to be recorded. One individual, in particular, spent many hours helping me understand topics related to the history of climate-change planning within the agency as well as the professional culture of the agency in general. As Bernard (2011) argues, to study a well-defined cultural domain such as the domain of water management as it relates to sea level rise impacts in South Florida, a sample of 10 to 20 knowledgeable people will provide a reliable measurement of the phenomenon under study. 


\section{Data Analysis}

I analyzed CCATF meeting minutes and audio recordings, official documents, such as policy papers, legislation and formal planning reports that articulate planning goals, missions and implementation strategies for climate change as developed by local and regional water management agencies. I used deductive text analysis and coding via MAXQDA qualitative data analysis software to systematically analyze these documents. Further on I used critical discourse analysis to identify the type, content and context of the political rhetoric under which the planning reports integrate. The planning reports under analysis enter the category of policy making, which usually includes the formulation of tasks, programs, and bureaucratic decision making (Reisigl 2008). According to Reisigl (2008) the goals of such rhetoric are political justification and instruction. Comparing and contrasting these texts and situating them in the larger cultural context of water management in South Florida, helped me identify not only what is stated but also, what was left out of these texts and its different hidden meanings (Hannam 2002). 


\section{References}

Adger, W Neil ; Hughes, Terry P ; Folke, Carl ; Carpenter, Stephen R ; Rockström, Johan. 2005. "Social-Ecological Resilience to Coastal Disasters." Science (New York, N.Y.) 309 (5737): 1036.

American Anthropological Association Meeting (2007), Susan Alexandra Crate, Mark Nuttall, and Society for Applied Anthropology Meeting (2007). 2009. Anthropology and Climate Change : From Encounters to Actions. Walnut Creek, CA: Left Coast Press.

Arun Agrawal. 2011. "Economics: A Positive Side of Disaster.” Nature 473 (7347): 291.

Banerjee, Subhankar. 2012. Arctic Voices : Resistance at the Tipping Point. 1st ed. New York: Seven Stories Press.

Blake, Nelson Manfred, Christopher F. Meindl, Steven Noll, and David Tegeder. 2010. Land into Water--Water into Land: A History of Water Management in Florida. 2nd ed. Gainesville: University Press Of Florida.

Bolin, Inge. 1998. Rituals of Respect: The Secret of Survival in the High Peruvian Andes. University of Texas Press.

Bolin, Inge, David Guillet, and William P. Mitchell. 1993. Irrigation at High Altitudes : The Social Organization of Water Control Systems in the Andes. Society for Latin American Anthropology Publication Series ; v. 12. [Arlington, VA: Society for Latin American Anthropology, American Anthropological Association.

Bush, Kathleen F ; Luber, George ; Kotha, S. Rani ; Dhaliwal, R.S ; Kapil, Vikas ; Pascual, Mercedes ; Brown, Daniel G ; Frumkin, Howard ; Dhiman, R.C ; Hess, Jeremy ; Wilson, Mark L ; Balakrishnan, Kalpana ; Eisenberg, Joseph ; Kaur, Tanvir ; Rood, Richard ; Batterman, Stuart ; Joseph, Aley ; Gronlund, Carina J ; Agrawal, Arun ; Hu, Howard. 2011. "Impacts of Climate Change on Public Health in India: Future Research Directions." Environmental Health Perspectives 119 (6): 765.

Castree, Noel ; Kitchin, Rob ; Rogers, Alisdair. n.d. Swyngedouw, Erik. Oxford University Press. http://www.oxfordreference.com/view/10.1093/acref/9780199599868.001.0001/acref9780199599868-e-1834.

Climate Change and Indigenous Peoples in the United States: Impacts, Experiences and Actions. 2014. Cham: Springer International Publishing. http://dx.doi.org/10.1007/978-3319-05266-3.

Crate A. Susan. 2011. "Climate and Culture: Anthropology in the Era of Contemporary Climate Change." Annual Review of Anthropology 40: 175-94. 
Crate, Susan A. 2008. "Gone the Bull of Winter? Grappling with the Cultural Implications of and Anthropology's Role(s) in Global Climate Change." Current Anthropology 49 (4): 569.

Davis, Steven J. ; Shearer, Christine. 2014. "A Crack in the Natural-Gas bridge.(CLIMATE CHANGE).” Nature 514 (7523): 436.

Davis, Mike, and American Council of Learned Societies. 2006. City of Quartz Excavating the Future in Los Angeles. New ed. ACLS Humanities E-Book. London ; New York: Verso. http://ezproxy.fiu.edu/login?url=http://hdl.handle.net/2027/heb.01817.

Demeritt, David. 2001. "The Construction of Global Warming and the Politics of Science." Annals of the Association of American Geographers 91 (2): 307-37. doi:10.1111/00045608.00245 .

. 2006. "Science Studies, Climate Change and the Prospects for Constructivist Critique." Economy and Society 35 (3): 453-79. doi:10.1080/03085140600845024.

De Sherbinin, A ; Castro, M ; Gemenne, F ; Cernea, M M ; Adamo, S ; Fearnside, P M ; Krieger, G ; Lahmani, S ; Oliver-Smith, A ; Pankhurst, A ; Scudder, T ; Singer, B ; Tan, Y ; Wannier, G ; Boncour, P ; Ehrhart, C ; Hugo, G ; Pandey, B ; Shi, G. 2011. "Climate Change. Preparing for Resettlement Associated with Climate Change." Science (New York, N.Y.) 334 (6055): 456.

"Employment and Labor." 2013. Web. The Beacon Council. http://www.beaconcouncil.com/meet-miami-dade-county/employment-andlabor?Page $=$ majorEmployers.

Eriksen, Siri H. editor, Tor Håkon editor Inderberg, Karen L. editor O’Brien, and Linda editor Sygna. 2015. Climate Change Adaptation and Development : Transforming Paradigms and Practices. Abingdon, Oxon; New York, NY: Routledge.

Evans, M. 2012. Shearer, Christine. Kivalina: A Climate Change story.(Brief article)(Book Review). Vol. 49. American Library Association CHOICE.

Few, Roger; Brown, Katrina; Tompkins, Emmal. n.d. "Public Participation and Climate Change Adaptation: Avoiding the Illusion of Inclusion." Climate Policy 7 (1): 46.

Fischhoff, Baruch. 1990. "Understanding Long Term Environmental Risks.” Risk and Uncertainty 315.

Fiske, Shirley J. 2009. "Global Change Policymaking from Inside the Beltway: Engaging Anthropology." In The Anthropology of Climate Change: From Encounters to Actions, edited by Susan A. Crate and Mark Nuttall. Walnut Creek, CA: Left Coast Press, INC. 
Godfrey, Matthew C., Theodore Catton, and United States Army Corps of Engineers. 2011. River of Interests : Water Management in South Florida and the Everglades, 1948-2010. Washington, D.C: Published for the U.S. Army Corps of Engineers, Jacksonville District, by the Government Printing Office. http://purl.fdlp.gov/GPO/gpo29059.

Grundwald, Michael. 2007. The Swamp - The Everglades, Florida, and the Politics of Paradise. Simon and Schuster Paperbacks.

Hastrup, Kirsten. 2014. Anthropology and Nature. Routledge Studies in Anthropology ; 14. New York: Routledge.

Hastrup, Kirsten, and Karen Fog Olwig. 2012. Climate Change and Human Mobility: Global Challenges to the Social Sciences. Cambridge [England] ; New York: Cambridge University Press. http://assets.cambridge.org/97811070/28210/cover/9781107028210.jpg.

Hieldegard, Diemberger; Hastrup, Kirsten ; Schaffer, Simon ; Kennel, Charles F. ; Sneath, David ; Bravo, Michael ; Graf, Hans - F. ; Hobbs, Jacqueline ; Davis, Jason ; Nodari, Maria Luisa; Vassena, Giorgio ; Irvine, Richard ; Evans, Christopher ; Strathern, Marilyn ; Hulme, Mike ; Kaser, Georg ; Bodenhorn, Barbara. 2012. "Communicating Climate Knowledge: Proxies, Processes, politics.(Report).” Current Anthropology 53 (2): 226.

Hitchcock, Robert K. ; Sapignoli, Maria ; Babchuk, Wayne A. n.d. "What about Our Rights? Settlements, Subsistence and Livelihood Security among Central Kalahari San and Bakgalagadi." The International Journal of Human Rights 15 (1): 62.

Hoffman, Susannah M., and Anthony Oliver Smith. 1999. The Angry Earth : Disaster in Anthropological Perspective. New York: Routledge.

Jasanoff, Sheila. 1990. The Fifth Branch : Science Advisers as Policymakers. Cambridge, Mass: Harvard University Press.

Leichenko, Robin M., and Karen L. O'Brien. 2008. Environmental Change and Globalization: Double Exposures. Oxford; New York: Oxford University Press.

Lipset, David. 2013. "The New State of Nature: Rising Sea-Levels, Climate Justice, and Community-Based Adaptation in Papua New Guinea (2003-2011).(Article)(Report)." Conservation and Society 11 (2): 144.

Maldonado, Julie ; Shearer, Christine ; Bronen, Robin ; Peterson, Kristina ; Lazrus, Heather. 2013a. "The Impact of Climate Change on Tribal Communities in the US: Displacement, Relocation, and Human Rights." Climatic Change 120 (3): 601. 
Marino, Elizabeth ; White, Dan ; Schweitzer, Peter ; Chambers, Molly ; Wisniewskp, Josh. 2009. "Drinking Water in Northwestern Alaska: Using or Not Using Centralized Water Systems in Two Rural communities.(Report)." Arctic 62 (1): 75.

Nicholls Robert J., Jason A. Lowe, David A. Vaughan, Tim Lenton, Andrey Ganopolski, Richard S. J Tol, and Athanasios Vafeidis. 2006. "METRICS FOR ASSESSING THE ECONOMIC BENEFITS OF CLIMATE CHANGE POLICIES: SEA LEVEL RISE.” ENV/EPOC/GSP(2006)3/FINAL. Organization for Economic Co-operation and Development - Environment Directorate; Environment Policy Committee - Working Party on Global and Structural policies. http://www.oecd.org/officialdocuments/displaydocumentpdf?cote=env/epoc/gsp $\% 282006$ \%293/final\&doclanguage $=$ en.

Nijman, Jan. 2007a. "Introduction - Comparative Urbanism." Urban Geography 28 (1): 1-6. - 2007b. "Introduction - Comparative Urbanism." Urban Geography 28 (1): 1-6.

Nungesser, M. ; Saunders, C. ; Coronado-Molina, C. ; Obeysekera, J. ; Johnson, J. ; McVoy, C. ; Benscoter, B. 2015. "Potential Effects of Climate Change on Florida's Everglades." Environmental Management 55 (4): 824.

Obeysekera, Jayantha; Park, Joseph. 2013. "Scenario-Based Projection of Extreme Sea levels.(Report)." Journal of Coastal Research 29 (1): 1.

Obeysekera, J., J. Park, P. Trimble, J. Barnes, J. VanAman, W. Said, and E. Gadzinski. 2011. "Past and Projected Trends in Climate and Sea Level for South Florida." Tehnical Report. Hydrologic and Environmental Systems Modeling. South Florida: South Florida Water Management District.

Obeysekera, Jayantha ; Kuebler, Laura ; Ahmed, Shabbir ; Chang, Miao-Li ; Engel, Vic ; Langevin, Christian; Swain, Eric ; Wan, Yongshan. n.d. "Use of Hydrologic and Hydrodynamic Modeling for Ecosystem Restoration." Critical Reviews in Environmental Science and Technology 41: 447.

Obeysekera, Jayantha ; Irizarry, Michelle ; Park, Joseph ; Barnes, Jenifer ; Dessalegne, Tibebe. 2011. "Climate Change and Its Implications for Water Resources Management in South Florida." Stochastic Environmental Research and Risk Assessment 25 (4): 495.

O’Brien, Geoff, Phil O’Keefe, Joanne Rose, and Ben Wisner. 2006. "Climate Change and Disaster Management.” Disasters 30 (1): 64-80.

Ogden, Laura. 2008. "The Everglades Ecosystem and the Politics of Nature." American Anthropologist 110 (1): 21.

Oliver-Smith, Anthony. 1996. "Anthropological Research on Hazards and Disasters." Annual Review of Anthropology 25: 303-28. 
Oliver Smith, Anthony. 2010. Defying Displacement: Grassroots Resistance and the Critique of Development. 1st ed. Austin: University of Texas Press.

"Progress Toward Restoring the Everglades: The First Biennial Review - 2006." 2006. Committee on Independent Scientific Review of Everglades Restoration, National Academies Press. National Research Council. http://www.nap.edu/catalog/12469/progress-toward-restoring-the-everglades-the-secondbiennial-review-2008.

Pielke, Roger; Gwyn Prins ; Steve Rayner ; Daniel Sarewitz. 2007. "Climate Change 2007: Lifting the Taboo on Adaptation." Nature 445 (7128): 597.

Romero-Lankao, Patricia. n.d. "Governing Carbon and Climate in the Cities: An Overview of Policy and Planning Challenges and Options.” European Planning Studies 20 (1): 7.

Schmidt, Gavin ; Archer, David. 2009. "Too Much of a Bad Thing: There Are Various--and Confusing--Targets to Limit Global Warming due to Emissions of Greenhouse Gases. Estimates Based on the Total Slug of Carbon Emitted Are Possibly the Most Robust, and Are worrisome.(CLIMATE CHANGE)(Report)." Nature 458 (7242): 1117.

Stensrud, Astrid B. n.d. "Climate Change, Water Practices and Relational Worlds in the Andes." Ethnos, 1.

Swyngedouw, E. (Erik) author. 2015. Liquid Power: Water and Contested Modernities in Spain, 1898-2010. Urban and Industrial Environments. Cambridge, Massachusetts: The MIT Press.

Swyngedouw, E. (Erik) editor of compilation, and Japhy editor of compilation Wilson. 2014. The Post-Political and Its Discontents : Spaces of Depoliticisation, Spectres of Radical Politics. Edinburgh: Edinburgh University Press. http://ezproxy.fiu.edu/login?url=http://site.ebrary.com/lib/FIU/docDetail.action?docID=1 $\underline{0909833}$.

Swyngedouw, E. (Erik). 2004. Social Power and the Urbanization of Water: Flows of Power. Oxford Geographical and Environmental Studies. Oxford ; New York: Oxford University Press.

Swyngedouw, Erik. 2010. "Apocalypse Forever?: Post-Political Populism and the Spectre of Climate Change.” Theory, Culture \& Society 27 (2 3): 213-32.

Teegavarapu, Ramesh S.V.; Goly, Aneesh ; Obeysekera, Jayantha. 2013. "Influences of Atlantic Multidecadal Oscillation Phases on Spatial and Temporal Variability of Regional Precipitation Extremes." Journal of Hydrology 495 (July): 74. 
The Beacon Council. 2013. "2013-2014 Annual Report to the Community." miami.beaconcouncil.com/webdocs/Marketing/TheBeaconCouncil-AnnualReport2014.pdf.

Thompson, M. (Michael), and Marco Verweij. 2006. Clumsy Solutions for a Complex World: Governance, Politics and Plural Perceptions. Global Issues Series. Basingstoke [England]; New York: Palgrave Macmillan. http://www.loc.gov/catdir/enhancements/fy0643/2006046012-b.html.

Thornton, Thomas F. ; Manasfi, Nadia. n.d. “Adaptation--Genuine and Spurious:

Demystifying Adaptation Processes in Relation to Climate change.(Report)" 1: 132.

Verweij, Marco ; Douglas, Mary ; Ellis, Richard ; Engel, Christoph ; Hendriks, Frank ; Lohmann, Susanne ; Ney, Steven ; Rayner, Steve ; Thompson, Michael. 2006. "CLUMSY SOLUTIONS FOR A COMPLEX WORLD: THE CASE OF CLIMATE CHANGE." Public Administration 84 (4): 817. 


\section{URBAN DEVELOPMENT AND CLIMATE CHANGE ADAPTATION}

\section{Introduction}

Anthropologists have long argued that adaptation to climatic events or change entails a major shift in the norms and rules that guide the experiences of a society (Oliver-Smith and Hoffman 2001). More precisely, adaptation entails major shifts in behaviors, which includes technological responses that aim at improving living conditions on all levels of experience including a culturally meaningful life (Fiske, 2014). But more importantly anthropologists have showed that adaptation is shaped by the realities of place, such as its historic legacies, its economy, its social structure, perceptions and knowledge (Crate and Nuttal 2009). In this first chapter I present the ways in which South Florida's historic legacies relate to urban growth and inform the types of climate-change concerns and adaptions its leaders seek.

\section{Climate Change and South Florida's Realities}

By the late 1990s, and particularly in 2001 when President Bush withdrew his support for the Kyoto Protocol, the difficulty of negotiating an agreement to reduce reliance on fossil fuels made climate change an important concern for world leaders and local governments alike. Globally, climate change poses a few major problems; more specifically, who is responsible for the already experienced climate-change impacts in places like the Arctic, Africa, South Pacific Islands, and other low-lying lands that have had little to do with the post-industrial spike in $\mathrm{CO}^{2}$ emissions? Timothy Finan (2010), for example, shows how climate change already exacerbates flooding vulnerabilities in Bangladesh and endangers the lives of many, particularly poor farmers working on the shrimp aquaculture industry. Also, Donna Green (2010) presents similar life-threatening 
vulnerabilities the people of the Torres Islands face. ${ }^{12}$ Also, in contexts of ever-shrinking land surface, researchers have asked how will increasing numbers of environmental refugees be re-settled (Oliver-Smith 2010). Finally, the global climate-change debates are often dominated by questions about who should be made financially accountable for the current state of the global climate and the impacts this has on non-industrial states and territories. In sum the concerns that climate change raises today can be categorized in terms of responsibility, accountability, and social justice (Crate and Nuttal 2010, 11). While these broad questions can be, at least partially, brought to bear at the local level, South Florida's climate-change concerns are shaped by past and current urban-growth models. Several studies have criticized South Florida's urban growth model (Blake 1980; Carter 1974; Grundwald 2006). These studies show how South Florida's development was largely driven by visions of surreal economic gain through agricultural and real estate development. In the following pages I focus on presenting the way real estate development became a crucial component of both the state and regional economy. Even though agriculture remains an important part of South Florida's economic and political life, real estate is at the center of climate-change adaptation planning.

\section{South Florida's Development}

South Florida's real estate economy has been key to Florida's early economic development. The historical accounts on South Florida's urban development begin with descriptions of the ways South Florida was shaped by various economic development visions. These visions include Florida as a paradise for growing tropical fruits, a breadbasket for the nation, as well as Florida as the playground of the rich (Grundwald 2006)

\footnotetext{
${ }^{12}$ Situated between Australia and Papua New Guinea.
} 
These visions began materializing in 1845 when Florida became the $27^{\text {th }}$ US state. Ten years latter, a railroad investor, and one of Florida's first political leaders, David Yulle, helped shape the Swamplands Act of Overflowed Lands which provided Florida's leaders with substantial federal revenue for improvement projects. To manage these funds, state leaders created the Internal Improvement Fund (IIF), which will become the first water management agency in the state (Grundwald 2006, 56).

Much of the historical water management literature (Blake 1980; McCally 1999) shows how the practices of the IIF have created a strong dependence between the state's economic and political survival and the land speculative enterprise. The IIF period (end of $19^{\text {th }}$ century to early $20^{\text {th }}$ century) can be largely characterized as both formative and exemplary of the way private interests used the political standing of the state to amass land and channel federal funds towards their private investments.

First of all, the IIF granted most of its federal funds to Yulee's private railroad enterprise as well as to a few ongoing small drainage projects (Grundwald 2006, 67). The intricate history of buying and selling land through IIF is described in the October 1941 of Florida's Historic Quarterly. ${ }^{13}$ This research shows that after the Civil War, the IIF went into bankruptcy as a result of numerous corrupt deals. Desperate to recover some of its financial standing the IIF sold the only land it had left in its possession, the southern part of Everglades; in addition it continued a politics of encouraging private drainage projects in an attempt to increase the availability of land in the region. However, drainage was largely unsuccessful until 1881 when Hamilton Disston signed a contract with the IIF to drain 12 million acres of swampland in exchange for half of the drained land, while

${ }^{13}$ Volume 20, Issue 2 
receiving 4 million acres of property upfront (Grundwald 2006, 106). The Disston deal ended IIF's financial problems for a while and marked the beginning of South Florida's first demographic growth. Hamilton Disston's ambitious project was extremely costly. To be able to fund it, Disston established the first real estate business in South Florida. South Florida's land was advertised in immigration offices all over Europe and the US (Grundwald 2006, 107). To be able to advertise and sell property, Disston built the first planned cities, and successfully established Florida's first $19^{\text {th }}$ century farming colonies. His business model of real estate speculation attracted the attention of numerous investors and by the end of the $19^{\text {th }}$ century, Henry Flagler was making some of the most impressive investments in the region; building railroads and state-of-the-art-hotels, Flagler made possible the expansion of citrus as well as other farming businesses in previously inaccessible areas of the Southeastern Florida. By the late 1870s the railroad reached up to today's region of West Palm Beach where he established entire cities, providing all types of services from water works to electricity. Flagler calculated that for every resident established permanently in the region, he would gain $\$ 300$ annually only from railroad use; therefore the initial high costs of drainage and railroad construction was seen as a long-term investment (Grundwald 2006, 108). The 1894 winter convinced him to seek extension of his railroad as well as of his real estate industry further south into today's Miami. This was largely due to the fact that Miami was the only region where temperatures had not fallen below the freezing point. Here, Flagler transformed the old military fort known then as Fort Dallas into a flourishing city. Using Disston's advertisement model, Flagler focused all his efforts on attracting permanent settlers. Flagler build hotels, dredged Biscayne Bay to create a port, and even donated money to 
create a US meteorological station to advertise Florida's tropical climate (Grundwald, 2006, 107).

By the end of the $19^{\text {th }}$ century, South Florida's swampy lands had become a great asset. Private investors as well as the state's IIF leaders saw land speculation as a great economic opportunity. Massive advertising campaigns stand as proof to this period's aggressive land economy. For example, the IIF sponsored in 1912 a four-day media tour of the Everglades canals and the existing two farms, and promised that in just a few months of continuous drainage work the whole region would be ready for further construction. A federal investigation soon found that the IIF had conspired with private land speculators to bribe an engineer and produce a report that grossly overestimated the ease of drainage while underestimating its costs (Grundwald 2006, 157). To counteract this nation-wide scandal, the real estate industry generated an even more aggressive advertisement campaign. For example, a brochure created by the Jaudon Realty in $1923^{14}$ notes in bright red letters "Guaranteed Leasehold Income, Land Ownership, Insurance Against Loss" and "You join us in an industry, not a land speculation" Florida's "Rising Values are Making Millionaires."

These types of brochures circulated all over the United States and were backed by several studies, often conducted by private interests, such as the Book of Florida published in 1925, which described Miami as a "treasure house of permanent wealth, a

\footnotetext{
${ }^{14}$ Brochures Selling Land in the Everglades; Reclaiming the Everglades Collection. Florida Archives. Digital Collection. Digitized from papers at the Historical Museum of Southern Florida, Miami.
} 
city of opportunity of permanent achievement" (The James Johnes Company 1925, 39). ${ }^{15}$

The book reveals some of the most important criticisms that Florida's development had received at the time. The overall argument of the book is that Miami's economy is not based in speculation, but rather in robust economic activities,

Miami has been misrepresented in a flood of articles which give the impression that it is a boom town" ... its growth has been steady, and will continue due to the satisfied investors. Can you call a city a boom town, whose building permits last year were close to $\$ 30,000,000$ in greater Miami, and whose building permits in the same area this year will exceed $\$ 60,000,000$ and all of which is materialized in concrete, reinforced concrete and everlasting coral stone? These are surely not the materials of which a boom city is made (41).

According to the above study, the Miami had recorded an increase of 440 percent between the 1910 and 1920 (The James Johnes Company 1925, 23). This was unprecedented in any urban region in the US. Historic accounts speak of land being sold by "the gallon", making reference both to the swampy nature of the region's terrain as well as to the fast pace of the land speculation economy (Blake 1980). Even though this growth was partially dampened by the 1920 and 1940 floods, as well as the economic depression, state and private interests continued to successfully advertise and sell much

\footnotetext{
${ }^{15}$ The James Johnes Company 1925. Book of Florida. Florida Everglades Archival Collection; Publication of Archival Library and Museum Materials. State University Libraries of Florida (PALMM Collections)
} 
of Florida's lands; as a result the state population grew steadily. The 1940' first largescale flood protection project, sponsored by the federal government effaced any remaining doubts about the region's economic potentials.

However, by the 1960s, Southeast Florida experienced its first major water crisis; this event raised important questions about the region's unsustainable growth patterns for the first time (Carter 1974). Urban growth was encroaching on much of the remaining Everglades creating imbalances that further compounded the earlier century's water diversions. The Everglades is a key component in the replenishing cycle of the freshwater Everglades. Population growth had affected the reserves of the regional aquifer through over extraction, while expansion of the built environment on these lands had further affected the aquifer due to loss of permeability as well as septic tank pollution. In addition, while expansion in the Everglades was cheaper it also required expensive investments in transportation and water and sewer infrastructure (Carter 1974). The rapid pace of urban development meant that oftentimes there was a gap between the time when developments were built and occupied and the ability of regional administration to respond with appropriate infrastructure. Sewage treatment became especially problematic, as private septic tanks installments were often faulty and resulted in aquifer pollution (Carter 1974).

According to Carter's research, scientist argued that only $1 / 3$ of the total land in Florida tolerated intense development, while most of South and South West Florida had very low or no tolerance to development (Carter 1974, 93). Activists and scientists are known to have lobbied against development or for more sustainable patterns of development since the 1940s (Villiesis 1997). In the 1970s sustainable development 
meant a shift from haphazard patterns of development to a comprehensive urban development plan that would capitalize on existing infrastructure and, most importantly, on the impacts development had on the environment (Carter 1974). While the 1970 environmental activism emerged as a power player in the region's politics (Godfrey and Catton 2011), urban growth continued in an unplanned manner until the end of the 1970s, when planning reforms established an Urban Development Boundary (the UDB) to protect the sensitive lands of the Everglades, which are crucial in the region's freshwater replenishing cycle. ${ }^{16}$

If in the first part of the $20^{\text {th }}$ century, Miami's real estate industry was advertised particularly to wealthy northerners, beginning with the 1960s Cuban migration, the real estate market not only experienced a change in clientele, but it slowly emerged and expanded to become a Latin enterprise. Wealthy Anglo communities grow in largely exclusive places, like Coral Gables (Grenier and Morrow (1997).

Beginning with the 1970s and 1980s, Miami was increasingly known as the capital of Latin America as wealthy and middle class residents from these countries saw Miami as a safe place to invest their savings. Many Latin businesses established headquarters in Miami, as waves of poor migrants from Central America filled the workforce needs of the growing service industry. Anticipating the opportunities that increased wealth in Latin America experienced in the last couple of decades, the real estate industry in Miami

\footnotetext{
${ }^{16}$ As I show in the following chapter, the western urban development (the UDB) remains a contentious topic. The UDB has been challenged and pushed further westward several times since then, including in 2008 at the request of the region's real estate industry (see CCATF Minutes, 2008). In addition to the negative impacts of development on the region's water, climate-change impacts are expected to affect freshwater availability due to factors like increased evapotranspiration and salt-water intrusion in the aquifer.
} 
responded. Building on the power relations that the Cuban enclave established since the early 1970s, Latin businesses, particularly realtors and developers established themselves as important political entities (LBA 2015). ${ }^{17}$

Today the most avid buyers and investors of real estate are from Latin America (Favela 2015). Also known as the capital of Latin America, Miami's real estate industry is largely sustained by capital from this region. Based on the 2014 Miami International Buyer Survey, approximately $68 \%$ of Miami's real estate buyers are of foreign origin (Favela 2015).

In this section I have showed how South Florida developed out of a few speculative private-interests visions engaged early on by a state politics that was shaped by a growth economic model. The state administration often defended these visions despite of devastating hurricanes, economic depressions, and potentially catastrophic environmental impacts. In the following sections I bring attention to the ways in which historical patterns of urban growth have shaped some of today's climate-change vulnerabilities; in the final section of this chapter I show that the real estate industry does not seem to consider the impacts of climate change as financially risky, despite the dire predictions that climate scientists make, particularly in terms of coastal flooding impacts.

\section{Climate Change Vulnerabilities in Miami}

One of the most evident consequences of climate change is sea level rise and the threat that it poses on the coastal built environment. Some of these consequences were

\footnotetext{
${ }^{17}$ Latin Builders Association, INC, http://www.lbaorg.com/about-us/history/ (accessed May 29 2015)
} 
noted as early as 1981 when two geologists, wrote the following in a report sent to the Miami Herald, one of the region's popular newspaper:

How do we plan for a future based on a reduction in land area, a progressive loss of freshwater supply, retreating barrier shorelines, and a gradual inundation of toxic dumpsites? Can we afford to continue encouraging urban growth and permitting major development projects on land that is only a few meters above sea-level? (Wanless and Harlem 1981, 2) ${ }^{18}$

While sea level rise was rarely discussed in scientific or media contexts, in the past few years, and most notably after the notorious 2013 Rolling Stone Magazine, "Goodbye, Miami” front page article about Miami becoming the new American Atlantis (Goodell 2013), apocalyptic scenarios of climate change have become common in local and national media. Concerns with decreased freshwater supplies, retreating barrier islands, inundation of toxic dumpsites, as well as shrinking land areas are all a part of the ethical concerns raised by climate-change activists and scientists. A search for media reports related to the impacts of climate-change in Miami results in a list of 99 newspaper articles that discuss these impacts. ${ }^{19}$ These articles touch on issues related to flood insurance costs, ${ }^{20}$ loss of coastal land, potential economic impacts on the industry, ${ }^{21}$ or

\footnotetext{
${ }^{18}$ For simplification purposes, I will refer to this report as the Barnacle Report

19 These articles were written between 2007 and 2014. A general search using Miami and climate change as key words returns over 800 titles.

${ }^{20}$ Journal of Commerce, April 22, 1999 (4)
} 
state politics in relation to the real estate industry. ${ }^{22}$ All of these articles discuss Miami's urban growth from one perspective or another.

In 2008, Miami Dade County's Climate Change Advisory Task Force (the Task Force) submitted a preliminary research paper on the impacts of sea level rise to the Miami-Dade County's Board of County Commissioners. The authors, members of the Task Force, noted that a preliminary analysis of the IPCC two-foot sea level rise projection would have devastating consequences for the Southeast Florida region. Among these consequences the report noted that in addition to four to five feet higher Spring tides, higher storm surges, frequent flooding of the barrier islands, pollution of freshwater aquifers with salt water, the county will experience a drastic reduction in land area (CCATF - STC Minutes 2008, 3) ${ }^{23}$ The Science Committee report carefully documented the scientific evidence that supported these claims and argued that these scientific findings form the core motivation for the recommendations that the Task Force was developing.

My overview of the Task Force activities, including their recommendations to the County Commissioners as well as interviews with former Task Force members and participant observation at numerous climate-change meetings during the 2011-2014 period, show that adaptation concerns center around the difficulty of reconfiguring urban

\footnotetext{
${ }^{21}$ San Jose Mercury News (California), November 28, 2013 Thursday, NEWS, 1163 words, By Daily News Staff Writer

${ }^{22}$ The Globe and Mail (Canada), February 2, 2008 Saturday, REPORT ON BUSINESS: INTERNATIONAL; BUSINESS TICKER: TOURISM; Pg. B8, 362 words, Bloomberg

${ }^{23}$ STC stands for Scientific Technical Committee. The STC is a sub-committee of the Miami Dade County Advisory Task Force.
} 
growth due to the financial and social justice problems that such reconfigurations imply. In the following pages I present these concerns as they emerge from my analysis of the Task Force meeting minutes and audio recordings.

\section{The Problem of Urban Growth}

To synthetize and analyze the concerns of the Task Force, I have conducted a content analysis of the adaptation recommendations that the Task Force members authored and submitted for approval to the county administration. I found that urban development was at the core of the Task Force's intellectual preoccupations and has shaped the ethical concerns of the region's climate-change culture and politics.

The intense preoccupation of the members of the Task Force with transforming Miami's urban development patterns is also evident in the document that outlines the final recommendation to the Board of County Commissioners (BCC). ${ }^{24}$ Most of the adaptation recommendations (12 out of 25) involved an urban development component, such as demanding modifications of land uses, building codes, or economic development strategies related to the built environment; this focus highlights the importance that the Task Force members gave to this problem. Figure 1 below presents a summary table of the number of urban development recommendations submitted by each of the three adaptation Task Force sub-committees. ${ }^{25}$ These, as well as the initial set of recommendations (submitted on March 2008) to the Miami-Dade County's Board of County Commissioners, asked the commissioners to limit development in areas that are

\footnotetext{
24 "Status of Recommendations August 2010"

${ }^{25}$ The Task Force organization in sub-committees is presented in the following chapter.
} 
vulnerable to sea level rise, particularly the coastal areas (CCATF Minutes, January 3, 2008). Task Force members argued that allowing developments to expand in areas that are either parks or agricultural areas would likely require costly adaptation measures from Miami's future taxpayers. ${ }^{26}$ More precisely, even if developments per se became the liability of private insurance companies or of their wealthy owners, the infrastructure connecting them would likely become a burden for Miami's taxpayers at large.

Climate-change recommendations were submitted twice during the four years of Task Force activities. The first set of recommendations, submitted in 2008, was carefully organized in terms of recommendations formulated by each of the sub-committees and each recommendation was followed by a justification (titled rationale, in the document). The rationale of these twelve recommendations points to important vulnerabilities for coastal developments as well as the interior or western ones. The county's elevations average at five feet above sea levels and as a result most of the region's built environment is at risk from some sea level rise impacts. In January 2008 when the Task Force members were debating the content of the first set of recommendations, several of them noted that one of the first and most important needs in terms of advancing a climatechange adaptation agenda is obtaining and refining county elevation data as this data, the text argued, would offer a more detailed understanding of the extent of Miami's physical vulnerabilities. During the same meeting, the Task Force chairman noted that obtaining the elevation data would paint a more vivid picture of the potential sea level rise scenarios for Miami's politicians and would allow the Task Force to justify the urgency with which these recommendations should be implemented (CCATF Recordings, January

${ }^{26}$ Here "development" refers to Miami's built environment 
11, 2008, minute 50-60). But while Task Force members focused on gathering needed scientific information to show the importance of rethinking urban development patterns, Miami's leaders grappled with questions related to the costs and responsibilities of adaptation.

\section{Financial and Social Responsibility}

A United Nations' report noted that by 2070, Miami-Dade County would be liable for $\$ 3$ to $\$ 5$ trillion in infrastructure repairs due to the impacts of sea level rise (Tompkins and Deconcini 2014). Today, Miami-Dade County is already burdened by massive financial needs for infrastructural repairs. The 2014-2015 financial plan allocates about $22 \%$ of its total budget to neighborhood and infrastructure repairs. ${ }^{27}$ Most of these funds, however, are needed for costly federal legal requirements related to water quality and water and sewer infrastructure repairs (Miami-Dade County Budget 2014-2015). As I show next, these allocations do not account for the necessary funds needed for Miami's water and sewer infrastructure needs.

\section{Miami-Dade County Water and Sewer Conundrum}

In March 2013, I participated in a small workshop organized by the Urban Land Institute (ULI), a non-profit research and planning organization serving the real estate industry nationally. One of the key speakers, Doug Yoder, director of Miami-Dade County's Water and Sewer Department and former Task Force member, clearly outlined

${ }^{27}$ This places infrastructure investment in the $3^{\text {rd }}$ place after expenditures allocated to public safety and transportation. There are eight major areas that the 2014-15 budget document outlines. These are Public Safety (29\%), Transportation (24\%), Neighborhood/Infrastructure (30\%), Health and Human Services (9\%), general Government (7\%), Recreation and Culture (5\%), Economic Development (3\%), and Policy Formulation (1\%). 
the conundrum his agency was facing. Miami-Dade County needed an investment of $\$ 13$ billion to replace and renew aging water and sewer infrastructure. Traditionally, repair and construction costs were supported through long term, low-interest bonds. However, this pattern of investment is no longer feasible as the agency's revenue (largely supported by water bills) lags behind the real cost of water. The inability to pay for the costs of replacement of water and sewer mains has been a problem in the past few decades, but recent development trends which favor the old urban core as well as expected development patterns driven by the potential impacts of climate change exacerbate this financial strain. More precisely, MDWSD has functioned by postponing costly replacements of aging infrastructure and invested in such projects only when these became absolutely necessary (i.e. when the water pipes failed). Aging infrastructure is concentrated in downtown Miami, where much of it is over 100 years old. Urban sprawl and western development has helped the Water and Sewer Department as developers cannot build on undeveloped land unless they pay the Water and Sewer Department for costs of connecting their developments with the existing infrastructure. As a result, the Water and Sewer Department had additional revenue sources and benefited from overseeing an infrastructure that required little maintenance (at least for its lifetime; approximately 50 years).

The Task Force recommendations, which have been integrated in the County's Sustainability Plan and the more recent 2014 County’s Comprehensive Planning Guide, demand a shift from suburban, sprawl-type development to a return to the old urban-core where an increase in density is more environmentally sustainable. Aside from the serious ethical problems created by gentrification (which I discuss later in this chapter) the 
aforementioned downtown real estate boom is not all bad. However, Miami-Dade County Water and Sewer Department's Deputy Director, Doug Yoder, noted that the densification of downtown Miami would require a complete re-design of the water infrastructure (Notes, ULI Workshop, March 2013). This design would have to drastically increase the system's performance capacities to meet the needs of the growing population. Current urban development laws do not require investors to fund necessary water and sewer repairs and expansions if these are made in already built environments such as downtown Miami. Therefore, not only would the Miami-Dade Water and Sewer Department revenue from sprawl developments, but building infrastructure for downtown redevelopment projects would support real estate interests, while placing financial burdens of the county's administration, and likely on Miami-Dade County's residents. Failure to respond to the increased capacity needs may result in ecological disasters with sewage spills in the ocean and freshwater aquifer. ${ }^{28}$

While the ethical problem of financial responsibility outlined above is rarely discussed in current climate-change adaptation planning contexts, the problem of freshwater availability is often noted. Scientists and water managers from around the region have mobilized in impressive research teams to study the impacts of saltwater intrusion on the freshwater wells. ${ }^{29} \mathrm{I}$ have learned about the difficulty of both understanding the extent of saltwater intrusion, the degree to which climate change would exacerbate these impacts, as well as the difficulty of diminishing these impacts, during

\footnotetext{
${ }^{28}$ See references for Waterkeeper vs Miami-Dade County

${ }^{29}$ the Miami Dade County Water and Sewer Department and United States Geological Survey is one of the most important research efforts conducted in this direction.
} 
my fieldwork at the District in 2014. While there seems to be little the county or region can do to stop sea levels from rising, it is well known that saltwater intrusion is largely a function of the health of the region's aquifers. ${ }^{30}$ More precisely, while sea level rises will pose additional pressures on the freshwater aquifer, increased freshwater withdraws from the region's aquifers is the main factor contributing to saltwater intrusion. Urban growth through real estate development is a major driver of water consumption. Therefore, while urban development and the real estate industry is at the center of creating Miami's multiple physical vulnerabilities to climate change, the larger taxpayer base is responsible for the financial costs of both infrastructure repair and expansion as well as for investment in alternative water sources. According to MDC-WSD documents, the current estimated $\$ 13$ billion cost of needed infrastructure repair and replacement is set to be paid through an increase in water costs of $6 \%$ for residential users and $4 \%$ for wholesale customers (MDC-WSD 2013).

While the region's leaders discuss the impacts of climate change and the difficult adaptation problems that it poses, questions related to human or social vulnerability are mostly voiced from outside the county bureaucracy. As I discuss next, social vulnerability is another aspect of Miami's urban growth historical legacies.

\section{Social Vulnerability}

Southeast Florida's social vulnerability to climate change is directly connected to past and present patterns of urban management. During a 2011 "South Florida and Sea level rise" tour organized by one of Florida International University's journalism

\footnotetext{
${ }^{30}$ I was told that the fuller the freshwater aquifer is the more capacity it has to maintain hydrostatic pressure and keep salty water further away from the freshwater wells.
} 
professors, I witnessed one of the few public discussion related to social vulnerability. The purpose of the tour was to instigate wider media interest in climate-change investigative journalism. Many of the former Task Force members were a part of this tour, and some of them had been invited as speakers. After getting to know the journalists invited to participate, we boarded a bus that drove from downtown Miami, along the Miami River; speakers pointed to Miami's climate-change vulnerabilities. One speaker offered a brief historical account and noted that some of Miami's poorest residents live in today's least sea level rise vulnerable neighborhoods. Forced here through segregation processes, these neighborhoods have elevations well above the rest of the county's averages. The overwhelming sea level rise vulnerability that the rest of the county faces makes these neighborhoods vulnerable to future gentrification processes. As I will discuss in the next section, Miami's downtown is already a preferred real estate investment location. Potential gentrification phenomena are partially addressed among the Task Force recommendations in the form of a call for affordable housing. However, social justice and vulnerability to climate change remain a sparsely addressed topic within climate-change adaptation planning contexts.

However, if climate change is likely to exacerbate flooding, for example, research shows that Miami's social vulnerabilities are unevenly distributed. The social and economic impacts that Hurricane Andrew had on this region offer a sobering image on the possible scenarios that climate change could have. Discussing the impacts of Hurricane Andrew, Peacock et al. (1997) argue that even though loss of life was insignificant considering the magnitude of this hurricane, some of Miami's communities experienced catastrophic impacts while others were able to navigate the event with ease. 
Overwhelmingly the poor and marginalized African-American communities suffered most. Their losses defy simple economic quantifications. Grenier and Morrow (1997), argue that the region's development history accounts in part for the uneven ways in which Miami's residents experienced this catastrophe. More precisely, this development has been guided by the whims of the economically powerful. African-American communities have traditionally been marginalized, first through segregation and later through a lack of access to the Cuban enclave. Nicole Dash et al. (1997) showed that even though cities like Florida City were among the most affected by the hurricane's impacts, these were among the last to receive assistance. Concluding the analysis of Hurricane Andrew's impacts, the authors noted that the "poor got poorer."

\section{Discussion and Conclusions: Climate Change, not a Financial Risk?}

I still remember my first visit to Miami during the 2006 summer. Eager to explore the city that would become my home during my graduate studies, I took a ride around downtown Miami. An overwhelming number of cranes and construction sites punctuated the cityscape. Indeed during the middle 2000s, just before the 2008 market crash, Miami was experiencing one of the largest housing booms in its history; 22000 condos were built only in downtown Miami in this brief period (Pristin 2013). Between 2004 and 2007, there were 80,055 new housing units built in the county (Census Bureau $\left.{ }^{31}\right){ }^{32}$ The

\footnotetext{
${ }^{31}$ Building Permit Estimates - U.S. State and Metropolitan Areas; http://censtats.census.gov/cgi-bin/bldgprmt/bldgdisp.pl (search by county and year; last accessed on January 8, 2015).

32 a report authored by the Miami-Dade County Office of Economic Development Coordination ("Miami-Dade Housing Market Assessment Report" January 15, 2009, Robert Cruz) noted that 22.856 building permits were issued in 2004, and 26,120 in 2005, a trend that continued until 2007.
} 
2007-2008 housing crash hit Miami's economy hard, as both lower income Miamians and wealthy real estate developers had to hand over many of their properties to the banks. ${ }^{33}$ Nevertheless, by 2012 only four years after being catalogued as the nation's worst real estate market crashes, Miami rose to the top again (Gerrity 2012). By 2014, the demand for real estate, particularly in downtown Miami, surpassed the supply and led the city into a new building boom. ${ }^{34}$ An analysis presented in The Economist $t^{35}$ (April 5, 2014) found that about 50 high-rise luxury towers were under construction and that the trend was expected to continue. An upscale $\$ 1.05$ billion Brikell City Centre project, which included the construction of 800 condos, begun in 2012 is expected to be completed by the end of 2015. Just within eyesight of this massive development there were another eight residential buildings under construction (Pristin 2013). Not only the real estate market is expanding today, but the center of this expansion is luxury real

\footnotetext{
${ }^{33} 8800$ properties were reposed by lenders in 2008 alone, while in 2007 138, 409 units were already vacant (Miami-Dade County Office of Economic Development, "MiamiDade Housing Market Assessment Report” January 15, 2009, Robert Cruz)

${ }^{34} 645$ thousand square feet were under construction in the Residential building construction sector in the fourth quarter of 2014, while 1.2 million square feet of industrial space was under construction at the same time according to a Miami-Dade County Regulatory and Economic Resources Department analysis: http://www.miamidade.gov/business/real estate.asp?fldrBriefing=2012\#3 (last accessed January 8, 2015).

35 "Erectile Resumption: Could the Miami Skyline one day resemble Manhattan's?" The Economist, April 5, 2014 http://www.economist.com/news/united-states/21600172could-miami-skyline-one-day-resemble-manhattans-erectile-resumption (accessed online on March 5, 2015); The article does not have the author name.
} 
estate. An analysis presented in the South Florida Real Estate News $(2015)^{36}$ noted an increased demand for significantly more spacious luxury condos. "More spacious" can mean anywhere from 3200 square feet to 12000 square feet, the article explains, and prices can reach up to $\$ 55$ million per unit. ${ }^{37}$ As water views remain in demand, it comes as no surprise that the developers choose places like North Miami Beach and Sunny Isles as building sites.

The frenzied real estate economy of Miami comes in sharp contrast to the stark reality of the expected multiple impacts from climate change. As I discussed in this chapter, scientists, planners, and water managers are all united in the belief that adaptation to climate change means a profound shift in Miami's urban growth patterns and all its related activities. At the same time, such profound change in Miami's planning culture seems impossible as Miami's economy remains today as it was since its early $20^{\text {th }}$ century beginning, tied to the needs of its real estate industry.

Discussing climate-change adaptation with former Task Force members, all my interviewees noted that representatives of the real estate industry have formed a dissonant voice among the Task Force's members; interviewees noted that some of the real estate representatives always seemed to argue against climate-change adaptation measures. A Bloomberg Business analysis (Meyer 2014) explains that climate-change adaptation planning could send a message of a problematic future for Miami real estate buyers, which could be extremely harmful to the real estate industry. While developers build and

\footnotetext{
${ }^{36}$ Kallergis Katherine and Sean Steward-Muniz. "Super-sized Condos Emerge as Demands Shift: Units Range from 2600 sf to 12000 sf." "The Real Deal", May 29, 2015. http://therealdeal.com/miami/blog/2015/05/29/super-sized-condos-emerge-as-demandsshift/ (accessed may 29, 2015).

${ }^{37}$ The size of a typical mansion starts at 8000 square feet according to this analysis.
} 
sell property in a relatively short time, their clients make investments based on long-term cost-benefit calculations. Developers fear that investments in real estate property would diminish substantially as soon as climate-change vulnerabilities are publicized in the adaptation planning process.

While this industry's risk calculations should not interfere with the county administration's calculations, in reality these risks are deeply intertwined. Given that the industry plays such an important role in the regional economy is no surprise that it also has such an important role in the county's formal politics. The real estate industry is proudly advertising its role in shaping Florida's building code and defining the expansion of Miami’s Urban Development Boundary (LBA 2015). My research on the climatechange planning culture in Miami-Dade County shows that these legislative pieces are among the most important components of proposals to design a more sustainable future for Miami. However, the problem of urban growth patterns shaped by the needs of the real estate industry is more complex. Cities like Miami Beach, for example, find themselves in a bind as their economic survival is largely dependent on the property revenues of its often-foreign residents. ${ }^{38}$ Limiting development because of measures to adapt to sea level rise is a potential economic catastrophe for the region. This is also true at the county level, where the real estate industry plays a key role in increasing property values and providing in this way substantial revenues for the county's operational budget.

\footnotetext{
${ }^{38}$ The Washington Post, "Before the sea rises" December 23, 2014 Tuesday, ASECTION; Pg. A01, 1736 words, Danielle Paquette
} 
The Miami-Dade County 2014-15 proposed budget document (MDC 2014), ${ }^{39}$ for example, shows that $30 \%$ of the county operational revenue comes from property taxes (65). Given the importance that real estate development has in the region's economy, it is not surprising that the apocalyptic depictions of climate-change impacts fail to dampen the massive development and redevelopment taking place today in downtown Miami and the region in general.

In this chapter I have shown that climate-change adaptation concerns center on issues related to urban growth. Historically, urban growth, sustained by a speculative real estate industry, has been the main engine of economic development in South Florida. While past patterns of urban growth have created a series of environmental problems, such as freshwater pollution and loss of aquifer recharge capacities, adapting to the impacts of climate change today is complicated by the fact that Miami's real estate industry on one hand exacerbates the impacts of climate change and on the other is Miami's most reliable financial resource for adaptive measures.

${ }^{39} \mathrm{http}: / /$ www.miamidade.gov/budget/library/FY2014-15/proposed/volume1/proposedbudget.pdf (accessed on March 3, 2015) 


\section{References}

Benzie, Magnus, Alex Harvey, and Karen Miller. 2011. "Adaptation in UK Cities: Heading in the Right Direction?" In Resilient Cities: Cities a Nd Adaptation to Climate Change Proceedings of the Global Forum 2010, edited by Konrad Otto-Zimmermann and Monika Zimmermann, 1st ed., 231-41.

Blake, Nelson Manfred, Christopher F. Meindl, Steven Noll, and David Tegeder. 2010. Land into Water--Water into Land: A History of Water Management in Florida. 2nd ed. Gainesville: University Press Of Florida.

Carter, Luther J., and Resources for the Future. 1975. The Florida Experience : Land and Water Policy in a Growth State. J. Floyd Monk Collection. Baltimore: Published for Resources for the Future by the Johns Hopkins University Press.

Crate A. Susan. 2011. "Climate and Culture: Anthropology in the Era of Contemporary Climate Change.” Annual Review of Anthropology 40: 175-94.

Christiansen, Jonathan. 2009. Four Stages of Social Movements. EBSCO Research Starters. At http://www.ebscohost.com/uploads/imported/thisTopic-dbTopic-1248.pdf

Dash, Nicole, and Betty Hearn Morrow. 2000. "Return Delays and Evacuation Order Compliance: : The Case of Hurricane Georges and the Florida Keys." Global Environmental Change Part B: Environmental Hazards 2 (3): 119-28. doi:doi: DOI: 10.1016/S1464-2867(01)00008-0.

Edelman, Marc. 2001. "Social Movements: Changing Paradigms and Forms of Politics." Annual Review of Anthropology 30 (January): 285.

Favela, Miho. 2015a. "Despite Latin Ameirca Slowdown, Miami Still Top Foreign Buyer Market." World Property Journal, April 14. http://www.worldpropertyjournal.com/realestate-news/united-states/miami-real-estate-news/miami-foreign-property-buyers-report2015-foreign-property-investors-in-miami-brazilians-buying-miami-condos-canadianproperty-buyers-in-florida-2014-miami-international-buyer-survey-9007.php.

Few, Roger; Brown, Katrina ; Tompkins, Emmal. n.d. "Public Participation and Climate Change Adaptation: Avoiding the Illusion of Inclusion." Climate Policy 7 (1): 46.

Finan, Timothy. 2009. "Storm Warnings: The Role of Anthropology in Adapting to Sea-Level Rise in Southwestern Bangladesh.” In Anthropology and Climate Change: From Envounters to Actions, edited by Susan A Crate and Mark Nuttall.

Fiske, Shirley J. 2009. "Global Change Policymaking from Inside the Beltway: Engaging Anthropology." In The Anthropology of Climate Change: From Encounters to Actions, edited by Susan A. Crate and Mark Nuttall. Walnut Creek, CA: Left Coast Press, INC. 
Gerrity, Michael. 2012. “After Historic 2008 Crash, Downtown Miami Among Nation's Most Active Residential Marckets in 2012." World Property Channel, March 13. http://www.miamidda.com/pdf/3.13.12\%20World\%20Property $\% 20$ Channel. $\% 20$ After $\%$ 20Historic $\% 202008 \% 20$ Crash, $\% 20$ Downtown $\% 20$ Miami $\% 20$ Among $\% 20$ Nation $\% 27 \mathrm{~s} \%$ 20Most $\% 20$ Active $\% 20$ Residential\%20Markets\%20in\%202012.pdf.

Gladwin, Hugh, Betty Hearn Morrow, and Walter Gillis Peacock. 2000. Hurricane Andrew : Ethnicity, Gender, and the Sociology of Disasters. Miami, Fla: International Hurricane Center, Laboratory for Social and Behavioral Research, Florida International University.

Godfrey, Matthew C., Theodore Catton, and United States Army Corps of Engineers. 2011. River of Interests : Water Management in South Florida and the Everglades, 1948-2010. Washington, D.C: Published for the U.S. Army Corps of Engineers, Jacksonville District, by the Government Printing Office. http://purl.fdlp.gov/GPO/gpo29059.

Goodell, Jeff. 2013. “Goodbye, Miami.” Rolling Stone, June 20. http://www.rollingstone.com/politics/news/why-the-city-of-miami-is-doomed-to-drown$\underline{20130620 .}$.

Green, Donna. 2009. “Opal Waters, Rising Seas: How Sociocultural Inequality Reduces Resilience to Climate Change among Indigenous Australians." In Anthropology and Climate Change: From Envounters to Actions, edited by Susan A Crate and Mark Nuttall.

Grundwald, Michael. 2007. The Swamp - The Everglades, Florida, and the Politics of Paradise. Simon and Schuster Paperbacks.

Hollander, Gail. 2005. "The Material and Symbolic Role of the Everglades in U.S. National Politics.” Political Geography 24 (4): 449.

McCally, David. 1999. The Everglades : An Environmental History. Florida History and Culture Series. Gainesville: University Press of Florida.

Meyer, Robert. 2014. "How Climate Change Is Fueling the Miami Real Estate Boom." Bloomberg Business, October 20. http://www.bloomberg.com/bw/articles/2014-1020/how-climate-change-is-fueling-the-miami-real-estate-boom.

Morrow, Betty Hearn, and Walter Gillis Peacock. 1997. Hurricane Andrew : Introduction. Miami, Fla: International Hurricane Center, Laboratory for Social and Behavioral Research, Florida International University.

Nicolas Nierenberg; Walter R. Tschinkel ; Victoria J. Tschinkel. 2010. “An Independent Thinker, Willing to Say What He Thought." Nature 466 (7305): 435. 
Oliver-Smith, Anthony. 1996. "Anthropological Research on Hazards and Disasters." Annual Review of Anthropology 25: 303-28.

Oliver-smith, Anthony. 2012. "DEBATING ENVIRONMENTAL MIGRATION: SOCIETY, NATURE AND POPULATION DISPLACEMENT IN CLIMATE CHANGE.” Journal of International Development 24 (8): 1058.

Pristin, Terry. 2013. "Miami Trying to Catch up Real Estate Demand." The Heral Tribune, May 13. http://www.heraldtribune.com/article/20130513/ARTICLE/305139989.

Roger Pielke ; Gwyn Prins ; Steve Rayner ; Daniel Sarewitz. 2007. "Climate Change 2007: Lifting the Taboo on Adaptation." Nature 445 (7128): 597.

Sharma, Divya, and Sanjay Tomar. 2010. "Mainstreaming Climate Change Adaptation in Indian Cities." Environment \& Urbanization 22 (2): 451-65.

Tompkins, Forbes, and Christina Deconcini. 2014. "Sea Level Rise and Its Impact on MiamiDade County." World Resources Institute. http://www.wri.org/sites/default/files/sealevelrise_miami_florida_factsheet_final.pdf. 


\section{CLIMATE CHANGE ADAPTATION PLANNING}

\section{Introduction}

In the previous chapter, I have argued that Miami's economic and political realities, shaped by a well-entrenched growth model of economic development, frame the region's climate-change adaptive concerns. In this chapter, I continue exploring this subject focusing on the ways these concerns emerged among some of Miami's scientists and leaders and the ways various actors engaged in processes of bureaucratization and mainstreaming. Bureaucratic mainstreaming is the process of making new societal values, goals, or ideals a part of the governing structures, largely through policy-making (Christiansen 2009). The Task Force meetings minutes and audio recordings provide key insights into these processes. This analysis is important because it offers insights into the obscure processes that take place when societal ideals change and directly confront a bureaucracy.

As I discussed in the introduction of this dissertation, the Task Force is a committee designed to provide Miami-Dade County's Board of County Commissioners (BCC) technical assistance on the potential impacts of climate change as well as best adaptation strategies. Towards the end of the Task Force meetings, I noticed an apparent theme: the Task Force members seemed to have made another attempt at forging social coalitions. I argue that the process of forging coalitions is part of a larger process of bureaucratization and mainstreaming of climate change concerns.

Broadly, this process began in the 1980s when some of local scientists expressed their concern for the impacts of climate change. In the 1990s ideas about climate-change mitigation were incorporated in the county's administrative tasks through the adoption of 
a carbon reduction program. While these two decades were largely shaped by the activities of several international organizations that focused on promoting mitigation at global scales, the 2000s saw a shift towards taking on local adaptation (Pielke et al. 2007). Capitalizing on the previous decades' mitigation activities, the Task Force emerged as a local forum for climate-change adaptation planning. Ideals such as changing urban growth laws or expanding mass transportation made headway as the Task Force forged social coalitions to help aid its relevance within the region's socio-political context.

\section{Literature Review}

In this chapter I use several concepts that have been discussed in the social movements literature. As I noted in the introduction, the Task Force is an advisory body partly shaped by Miami-Dade County's bureaucratic norms and rules. However, its fiveyear long existence has generated change within the county's bureaucracy. In this section I offer a brief description of the stages that social movement scholars have identified in the context of Rational Process theories. I argue that an analysis of climate change from the organizational perspective of social movement theories offers a framework for analyzing climate-change adaptation planning processes as an integral part of larger process of change. The Task Force is not a part of a local social movement; however, using concepts borrowed from the social movements literature, such as bureaucratization and mainstreaming, I show that the Task Force was in fact a site that affected change within the county's bureaucracy. In the following pages I discuss bureaucratization and mainstreaming as social movement concepts and highlight their usefulness in describing the activities of the Task Force. 


\section{Social Movements and their Lifecycles}

Social movement theorists have identified four stages in the lifecycle of a social movement. The first stage is known as the social ferment stage; it is largely characterized by the emergence of a discontent with an unpopular policy or a social condition. A few people might take individual action by writing a letter to the local newspaper, but these actions are not organized (Christiansen 2009,16). The second phase of a social movement, coalescence, is defined by a more clearly stated sense of discontent. The unrest is no longer individual and uncoordinated but becomes generalized and geared towards finding those responsible and able to make amends and make demands (17). Mass demonstrations are common in this stage, and the movement's leadership is defined. The third stage, bureaucratization is defined by "higher-level organization and coalition-based strategies"(18). At this point some success in raising awareness has already occurred, but the movement cannot rely any more on charismatic leaders. Instead it has to employ trained staff to carry on the goals of the movement. The movement benefits from greater political power and access to political elites. Research shows that many movements fail at this stage because of its difficult for members to sustain the emotional excitement necessary to continue with often volunteer-based demands (Macionis 2001). Finally, the last stage of a social movement is commonly known as the

decline. While decline might imply a negative process, social movement literature points out that the fourth stage can end in five major ways: repression, co-optation, success, failure and establishment with the mainstream (Christiansen 2009, 19).

Repression occurs when measures, often violent, are taken to end the movement; coptation occurs when the movement's leader associates with an authority or becomes 
part of an organization to change the policy targeted by the movement; therefore social change emerges through the bureaucratic system already in place. Success, as the name suggests, is defined by the fact that the movement's goal has been achieved. Miller (1999) argues that success is easy identifiable when the movement has very specific goals. In Miami one such example is the middle of the $20^{\text {th }}$ century movement to stop the construction of a jet airport in the middle of Everglades' Big Cypress Natural Reserve (Grundwald 2007).

A social movement can also decline though failure. Failure encapsulates the first two possibilities presented above as well as other problems, such as failure to grow at the same pace with the movement. A final decline possibility is broadly defined as establishment with the mainstream or mainstreaming. Mainstreaming occurs when the goals or ideologies of the movement are adopted by the mainstream political culture, and therefore there is no further need for the movement anymore (21). For example, the labor movement is considered such a successful decline. After being repressed for many years, labor laws are today largely integrated in the political and economic system (Macionis 2001 in Christiansen 2009, 22). The above summary of social movement stages describes a linear evolution where bureaucratization and mainstreaming are among the final stages of a social movement. In the following section, I present the intellectual milieus where ideas about the impacts of climate change converged to shape the Task Force. The Task Force then became the stage where bureaucratization and mainstreaming processes took off as scientists as well as county leaders and administrators began grappling for the first time with climate-change adaptation concerns. 


\section{Early Climate Change Concerns}

One day (in 1981) I passed over this bridge and took a picture of the barnacles' cause I had this old picture (since 1949) of the barnacles and let's see whether these have moved up. Sure enough, they did. We found out that the rate had moved up 6 or 7 inches (Interviews; November 12, 2013).

In this section I argue that Miami's climate-change concerns emerged in the context of national debates on the validity of climate-change science. According to local scientists, the barnacles below immortalized a global-physical phenomenon with potentially devastating consequences for Miami’s coastal communities. Their appeal to a local newspaper where the barnacles' photo accompanied a white paper describing the science of sea level rise and its potential local impacts was, however, contextualized by an already existing climate-change national debate. The barnacles became important scientific artifacts of climate change and motivated two local scientists to become political actors. At the national level, other scientists also saw climate change as a reason to take political action.

The 1980s were a transitional time for climate-change research. During the late 1960s and 1970s substantial research (see Charney et al. 1979 and MacDonald et al. 1979) had been conducted on the impact of $\mathrm{CO}^{2}$ on the global climate. ${ }^{40}$ However, at that

${ }^{40}$ Jule G. Charney, Akio Arakawa, D. James Baker, Bert Bolin, Robert E. Dickinson, Richard M. Goody, Cecil E. Leith, Henry M. Stommel, and Carl I. Wunsch, Carbon Dioxide and Climate:A Scientific Assessment, National Research Council, Ad Hoc Study Group on Carbon Dioxide and Climate (Washington, DC: National Academy Press, 
time, climate change was a scientific rather than political concern. Nierenberg (2010) argues that it was during the Carter administration that climate change jumped the scales (Hollander 2005) ${ }^{41}$ from science to politics (319). After the economic recession of the 1970s, largely a result of the oil embargo imposed by Middle East countries as well as in response to the Three Mile Island nuclear accident, president Carter $(1974)^{42}$ proposed an economic program that would focus on a direct use of domestic coal, development of solar power technologies, and production of synthetic fuels. Concerned with the intensification of the effects of $\mathrm{CO}^{2}$ emissions on the global climate, MacDonald, a geophysicist and the lead author of a climate change report (MacDonald et al. 1979),

1979).

G. F. MacDonald, H. Abarbanel, P. Carruthers, J. Chamberlain, H. Foley, W. Munk, W. Nierenberg, O. Rothaus, M. Ruderman, J. Vesecky, and F. Zachariasen, The Long Term Impact of Atmospheric Carbon Dioxide on Climate, JASON Technical Report, JSR-78-07, 1979.

These reports were calling for policy action and in 1983 an NAS detailed study of this issue; in 1983, NAS formed the Carbon Dioxide Assessment Committee (CDAC), which in 1983 produced a report called Changing Climate. It provided a thorough assessment of the problem but did not recommend immediate changes to the U.S. energy program.

${ }^{41}$ Hollander (2006) uses this expression borrowed from Cox 1998 to discuss the ways in which the famous 1988 Dexter Lehtinen lawsuit served as a catalyst for change and specifically for making the local environmental debate on the pollution of Everglades National Park a national problem.

${ }^{42}$ Jimmy Carter, "President's Commission on the Accident at Three Mile Island Remarks Announcing Actions in Response to the Commission's Report," 7 Dec 1979, the American Presidency Project, http://www.presidency.ucsb.edu/ws/?pid=31788 (last accessed 30 Mar 2010)

Roger E. Kasperson, Gerald Berk, David Pijawka, Alan B. Sharaf, and James Wood, "Public Opposition to Nuclear Energy: Retrospect and Prospect," Science, Technology, and Human Values 5, no. 31 (1980): 11-23; http://www.jstor.org/stable/689009 (last accessed 24 Nov 2009) 
argued that the economic program proposed by the Carter administration was a mistake (Niernberg et al. 2010). ${ }^{43}$

Picture 1: A University of Miami scientist took the two pictures under a bridge in the mangrove forests on the coast of Florida.

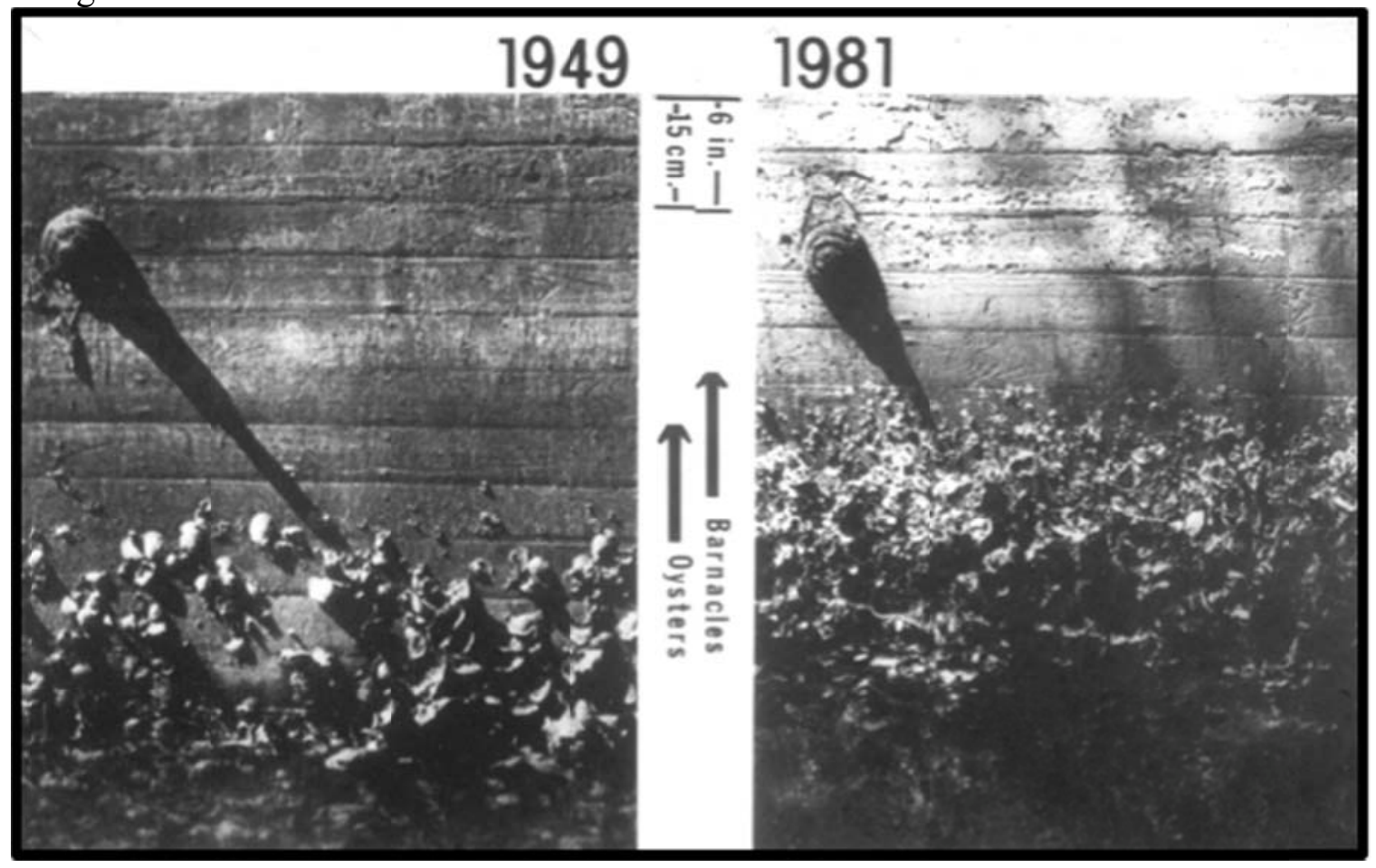

This article, as well as other scientific reports, sparked a national debate on the direction that the energy policy should take. Several studies were proposed and conducted on this issue. Particularly important is the 1983 National Academies of Science report. Many of these studies argued that an increase in $\mathrm{CO}^{2}$ was indeed problematic but concluded that more research was called for in order to be able to propose changes in existing policies (Nierenberg et al. 2010, 327). Therefore, in 1981, when my interviewee had taken the comparison picture of the barnacles in the coastal Everglades, the validity of climate change science was increasingly contested.

\footnotetext{
${ }^{43}$ Pomerance, "Dangers from Climate Warming" Washington Post; in Nierenberg (2010, 324)
} 
The move of the barnacles in response to changes in sea levels provided a powerful scientific proof on the already occurring impacts of climate change. On the day he had become aware of the move of the barnacles, the scientist noted: ...so, the barnacles had responded to that. So to me that was really powerful, as the animals could not care less about our intellectual processes, or doing this stuff. They were dealing with it, they were adapting to it. (Interviews;

November 12, 2013)

This remark carried an eerie tone which somehow allowed me to understand that the almost three and a half decades that had passed since he measured the move of the barnacles, only increased his dissent for pointless "intellectual processes." The report he had authored together with a fellow researcher, noted the importance of adaptation and pointed to the ethical questions posed by a continuation of traditional development patterns:

The evidence in hand, together with the possibility that sea level will continue to rise at a rapid rate, is sufficient to demand that all level of government begin re-evaluating coastal and community management policies.

Discussing this report with one of its authors, he noted that the report had been used as a scientific proof for a local newspaper article on sea level rise in 1983, but that sadly Miami's citizens and leaders, allowed the dust to settle on the adaptation matter until 2006, when the Task Force was created (Interviews; June 9, 2014). However, climate change continued to grow in importance in this two and a half decade, through a focus on 
climate-change research and mitigation. Climate-change mitigation means finding and implementing actions to reduce greenhouse gas (GHG's) emissions largely due to industrial activities (IPCC 2007).

By 1988, the World Meteorological Organization, along with support from the United Nations Environmental Program (UNEP), created the International Panel on Climate Change (the IPCC) to explore and assess the science of climate change. In the United States, the framework for the nation's energy policy followed the same basic tenets proposed by the Carter administration, while providing some funding to assess emission impacts. Around the same time, Miami-Dade County Clerk, Harvey Ruvin, became one of the founding members of what is known today as the ICLEI - Local Communities for Sustainability (ICLEI). ${ }^{44}$ ICLEI targeted small governments around the world to offer guidance in attaining more sustainable approaches to environmental management. In 2007, ICLEI's policy director argued that the main driving force of ICLEI was the idea that local governments have the greatest ability to implement environmental decision making (Minutes, February 23, 2007, page 3).

In 1992, the Kyoto Protocol treaty was signed and 192 nations volunteered to reduce greenhouse gas emissions; this was an important step forward in terms of international cooperation to create a sustainable global economy, and it was premised largely on the idea that developed nations, responsible for $55 \%$ of the global green-house gas pollution, would ratify this agreement. In 1993, Miami-Dade County became one of the first jurisdictions to join ICLEI, largely due to the active role that Miami-Dade

\footnotetext{
${ }^{44}$ See Dissertation Introduction for more details on this organization.
} 
County clerk had in this international organization. ${ }^{45}$ Becoming a member of ICLEI, Miami-Dade County committed to work towards reducing its emissions. Hosted under a County Carbon Reduction Program, this program infused the vocabulary of the local bureaucracy with the climate-change nomenclature.

In this section I focused on contextualizing the socio-political and economic environment in which concerns about climate change emerged in the Greater Miami region. As noted, ideas about the impacts of climate change, although controversial have rapidly become a part of the socio-political scene. In this first phase a few scientists concerned with the potential impacts of climate change crossed the boundary of scientific inquiry and began acting as political individuals. The ease of this transition was likely due to the rather privileged positions that scientists have in the political sphere. While many scholars have argued that scientists or experts have used their privileged positions to legitimate state authority (see Mitchel 2004), my research points to this privilege only in terms of the legitimating power that the scientist status offers when attempting to enter a policy-making arena. In the following section I provide insights into the ways scientific concerns are transformed once they become a part of the bureaucratic and administrative sphere of a society.

\section{Towards Mainstreaming}

By 2006, when the Task Force was created, it was clear that international and local efforts to negotiate climate-change mitigation were failing (Pielke et al. 2007). Attention shifted, in this context, from mitigation to adaptation.

\footnotetext{
${ }^{45}$ Harvey Ruvin's climate-change leadership has often been recognized in my interviews
} 
Table 3. Task Force Mainstreaming Processes

\begin{tabular}{|c|c|c|c|}
\hline $\begin{array}{l}\text { PROCESSES BY } \\
\text { THEMES }\end{array}$ & $\begin{array}{l}\text { IDENTIFYING } \\
\text { TERMS }\end{array}$ & $\begin{array}{c}\text { EXEMPLARY } \\
\text { RECOMMENDATIO } \\
\mathbf{N}\end{array}$ & $\begin{array}{l}\text { NUMBER OF } \\
\text { RECOMMENDATIO } \\
\text { NS /CODE OF } \\
\text { RECOMMENDATIO } \\
\mathbf{N}\end{array}$ \\
\hline $\begin{array}{l}\text { ASSES/ } \\
\text { MONITOR }\end{array}$ & Asses; identify; review & $\begin{array}{l}\text { Require all county } \\
\text { agencies to assess } \\
\text { climate change impacts } \\
\text { on the agency's/entity's } \\
\text { responsibilities (C1; } \\
\text { page 12) }\end{array}$ & $\begin{array}{l}10 \text { recommendations } \\
\text { A2; C1; C5; D6; D8; } \\
\text { D9; F1; F6; E6; E7. }\end{array}$ \\
\hline $\begin{array}{l}\text { CREATE NEW } \\
\text { POLICIES }\end{array}$ & Establish a policy & $\begin{array}{l}\text { Establish a } \\
\text { comprehensive planning } \\
\text { and zoning policy, such } \\
\text { as development } \\
\text { setbacks and limits on } \\
\text { density and } \\
\text { infrastructure in coastal } \\
\text { and transitional zones to } \\
\text { consider vulnerability to } \\
\text { sea level rise and salt- } \\
\text { water intrusion (D4; } \\
\text { page 16) }\end{array}$ & $\begin{array}{l}3 \text { recommendations } \\
\text { D4; C2; E5 }\end{array}$ \\
\hline $\begin{array}{l}\text { ATTRIBUTE } \\
\text { FINANCIAL } \\
\text { RESPONSABILITY }\end{array}$ & Fund; acquire; & $\begin{array}{l}\text { Increase funding and } \\
\text { resources for land } \\
\text { acquisition and } \\
\text { management programs } \\
\text { of Miami-Dade County } \\
\text { (D1; page 16) }\end{array}$ & $\begin{array}{l}6 \text { recommendations } \\
\text { D1; D2; D3; D5; D7; } \\
\text { E7. }\end{array}$ \\
\hline $\begin{array}{l}\text { BUREAUCRATIZA } \\
\text { TIZE } \\
\text { OR } \\
\text { BUILD } \\
\text { INSTITUTIONAL } \\
\text { SUPPORT } \\
\text { MECHANISMS }\end{array}$ & $\begin{array}{l}\text { Form collaborations; } \\
\text { create new task force; } \\
\text { create new working } \\
\text { group; convene; create a } \\
\text { memorandum; }\end{array}$ & $\begin{array}{l}\text { Convene local and state } \\
\text { agencies and water and } \\
\text { sewer utilities around a } \\
\text { discussion of climate } \\
\text { change impacts on } \\
\text { water quality, quantity } \\
\text { and availability and } \\
\text { implications for } \\
\text { infrastructure planning } \\
\text { and investment (F2; } \\
\text { page 23) }\end{array}$ & $\begin{array}{l}16 \text { recommendations } \\
\text { C3; C6; D10; E2; E3; } \\
\text { E4; E5; F2; F3; F4; } \\
\text { F5; F7; F8; F9; F11; } \\
\text { E5 }\end{array}$ \\
\hline $\begin{array}{l}\text { MODIFY } \\
\text { CURRENT } \\
\text { POLICIES }\end{array}$ & $\begin{array}{l}\text { modify; amend; change; } \\
\text { revise. }\end{array}$ & $\begin{array}{l}\text { The CCATF } \\
\text { recommends that } \\
\text { Miami-Dade County } \\
\text { advocate for } \\
\text { amendments to the } \\
\text { Florida Building Code } \\
\text { that will reduce the } \\
\text { impact of greenhouse } \\
\text { gas emissions and } \\
\text { improve climate change } \\
\text { resiliency (C8; page } \\
\text { 15). }\end{array}$ & $\begin{array}{l}7 \text { recommendations } \\
\text { C4; C7; C1; C4; F10; } \\
\text { C8; E1 }\end{array}$ \\
\hline
\end{tabular}


The Task Force represents an example of such transitions, as adaptation became the main organizing force of its activities. ${ }^{46}$ Adaptation is largely dependent on the socioecological characteristics of a place and it presents a high degree of complexity (Sharma and Tomar 2010; Few et al. 2007). Research shows that due to the managerial complexity that climate-change adaptation entails, planners focus first on mainstreaming climate change into the local planning operations (Benzie et al. 2011; Kates et al 2012; Sharma 2010). Using insights I gained from the social movement literature I argue that mainstreaming occurs only after and if the movement has managed to build a diverse social, or in this case administrative support for its cause, a key bureaucratization process. Equally important to the mainstreaming process is the ability of the movement to incorporate knowledge production processes of the bureaucracy it tries to transform into its own knowledge production processes.

\section{The Task Force Activities}

The Task Force meeting minutes and audio recordings show that its members were actively engaged in social coalition building processes. A content analysis of the final set of climate-change adaptation recommendations shows that the Task Force members viewed coalitions and collaborations as extremely important mechanism for building a climate-change adaptation institutional support. Table three shows that among

\footnotetext{
${ }^{46}$ Nevertheless, mitigation remained important. In the 2006 legislative session that created the Task Force, one of the commissioners noted that the $\mathrm{CO}^{2}$ mitigation project had been instrumental to the creation of the Task Force (July 18 2006, Board of County Commissioners meeting minutes). The $\mathrm{CO}^{2}$ initiative was largely a data collection project that offered important benchmarking and success measures that, together with increased scientific attention to climate change, were further used to discuss climate-change in terms of adaptation.
} 
the five broad recommendation categories, the theme of building institutional support is the most important. I use the term institutional to refer to all the county departments, administrative functions and regional agencies that inform and form the sources and structures of county governance. Recommendations that fall into the institutional support category have the highest frequency compared to the other four categories. The content analysis of the recommendations also shows that the Task Force members did not focus as much on designing new policies, as on acquiring a better understanding of the specific impacts of climate change, while targeting flexibilities within existing policies.

In the following pages, I describe the coalition building process, one of the Task Force's most important activities. My analysis of the Task Force meetings shows the Task Force produced a set of well-written, science-based recommendations, and outlined a rather holistic model of operation. At the same time, the four years of active meetings were not devoid of confusion and sometimes controversy. While trying to mainstream its goals (here the Task Force recommendations) into the County's planning practices, the Task Force members reached a confusing impasse. During the second part of its activities (from 2008 to 2010) Task Force members were focused on understanding the blockages that intervened to create this impasse.

They found that these blockages were likely due to the lack of success in forging coalitions with important groups of interests, as well as the incongruence that existed between the knowledge that the Task Force produced and the type of knowledge that the county bureaucracy functioned on.

Forging Coalitions: a Key Mainstreaming Building Block. My analysis of the Task Force meeting minutes shows that coalition building means identifying and then co-opting key 
individuals that could facilitate the integration of climate-change adaptation objectives with the mainstream planning bureaucracy. The Task Force members targeted either individuals who were associated with an agency that would be able to take on adaptation measures at the county or regional level (usually through regulatory power) or individuals that could provide insights into more obscure political processes that would allow the movement to advance its goals in strategic ways. They also identified key interest groups who were known to exercise political power as a result of their importance to the county's economy. As I show below the Task Force members formed coalition with the first two sets of key individuals, while the third group was more difficult to co-opt.

\section{Coalitions Forged Before the Official Task Force Meetings}

The success of building political support though coalitions had been tested precisely with the creation of the Task Force. At the June 6, 2007 Task Force meeting, Commissioner Seijas who had been the main supporter of the ordinance that defined the creation of the Task Force, noted:

Thank you Mayor Alvares! Your support for the Task

Force made a big difference for me when you came with

Mr. Harvey to discuss it ... it's a wonderful idea (Minutes;

June 6, 2007: minute 8)

Although left unsaid, it is clear that the support of the county's largest city "made a big difference" because of its electoral importance. This insight into the way the county's bureaucracy works was likely due to Harvey Ruvin's decades long career within this bureaucracy. Building these types of insider coalitions to support the Task Force mission became, thus, one of the organizing principles of the Task Force. As the different goals of 
the Task Force crystalized the advisory body designed separate sub-committees to tackle different climate-change policy issues. In Figure 1, below, I mapped in black the official organizational structure of the Task Force. In the first two years of its existence it worked directly under the Board of Government Operations and Environment, and starting in 2008 it began collaborations with the Board for Budget Planning and Sustainability. ${ }^{47}$

Figure 1: Task Force Organizational Structure

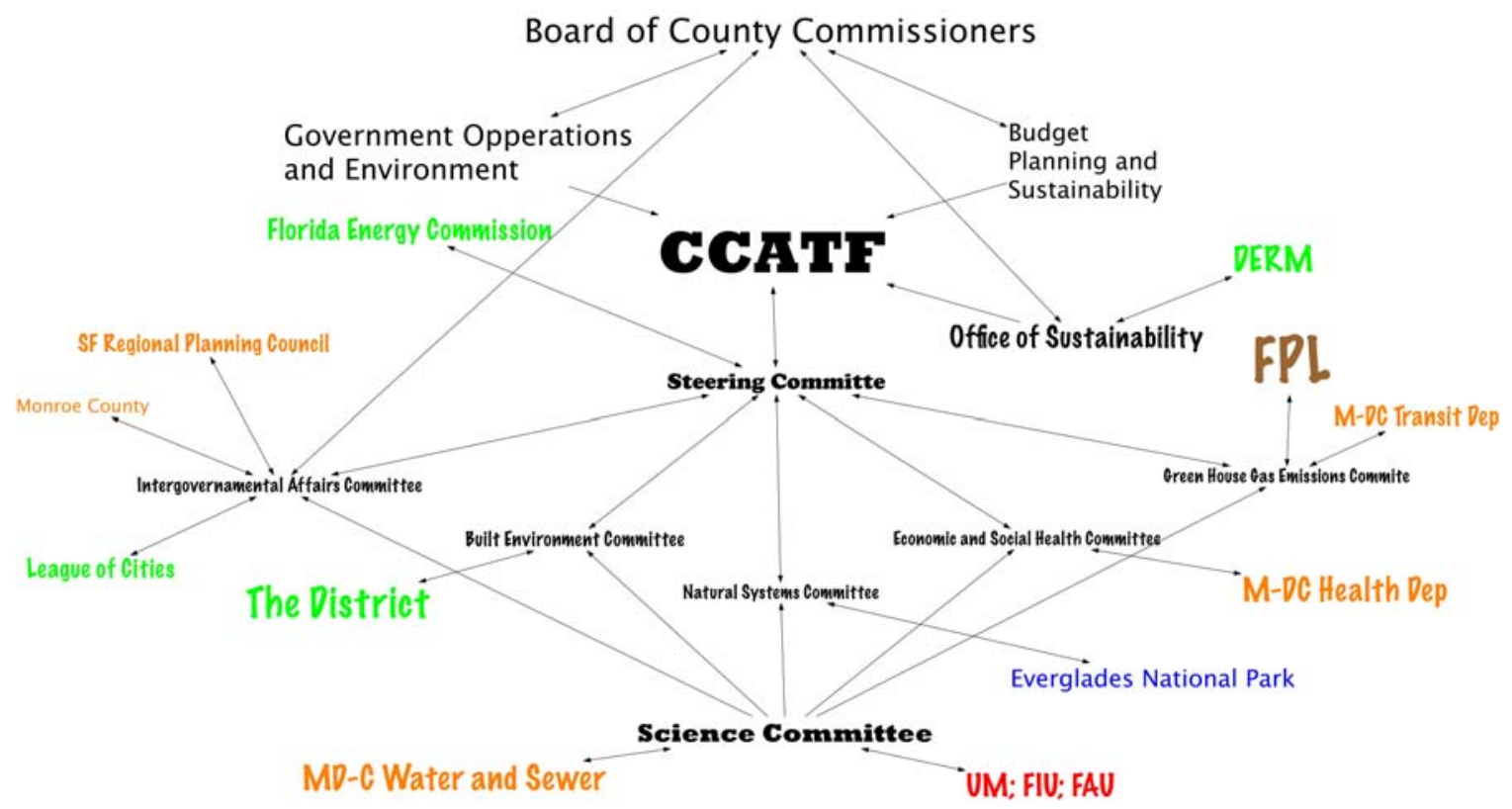

\section{Coalition-Building as a Task Force Activity}

The purpose of forging social coalitions is defined and justified from the beginning of the Task Force activities. As a matter of fact, this goal was so important that a special subcommittee was formed to focus only on this goal. The Intergovernmental Affairs Committee's stated mission reads:

${ }^{47}$ These were two separate boards that were chaired by two different County Commissioners. 
The Committee will also identify opportunities for collaboration with other government entities, where such action would enhance the ability of Miami Dade more effectively to address climate change. (Task Force Initial Report, Appendix II, May 8, 2007 - Committee Mission Statements; page 2)

As it is noted in this mission statement, coalition-building practices were an important way of building wide institutional support. However, coalitions were also important because they offered legitimacy. All the members and all the sub-committees engaged in the coalition building process. Each subcommittee had a chair and sub-chair that was responsible for building the expert-base of each of its committees. One subcommittee chair describes the ways in which some of these memberships were formed:

So I brought him in to give us a presentation. He ended up being on the committee. (Many) people came in to give us a presentation, and ... ended up sitting in on the committee (Interviews; June 9 2014).

But while the Task Force began with a set of 25 members appointed by different county commissioners, over the four active years of its functioning (2007 to 2010) the Task Force greatly expanded its membership base. For example, by the time the first Task Force report was written, after one year since its inaugural meeting, the Task Force members had met during a total of 55 meetings, involving 175 volunteer participants; a total of approximately 5000 hours spent discussing and working to prepare the first set of 
climate change recommendations (Minutes May 2, 2008; Exhibit 1: Chairman's Letter; page 1). The well-represented volunteer base of the Task Force is testimony to the increased coalescence of individuals that identified with this concern.

During the inaugural meeting of the Task Force, its chairman noted that one of its main challenges was to gain state and federal support for climate-change mitigation and adaptation strategies (Minutes, February 23, 2007). The chairman also noted that the lack of concern for the potential impacts of climate change had allowed a series of unsustainable county practices, such as urban sprawl, to persist. The Task Force members decided that increasing public awareness to climate change was key in this process. However, this task did not become a major focus during the four years of Task Force activities. Instead the Task Force members focused on identifying those regional agencies that were already showing some interest in climate change or that would be particularly affected in their operations by the impacts of climate change.

The District and the Regional Planning Council were the first agencies invited to discuss their research approaches to climate change. These presentations show that the focus on climate-change adaptation research and planning was very small at this time. Instead, these agencies, focus was on assessing vulnerabilities. Particularly important seemed the EPA funded project, led by the Regional Planning Council, which made an initial comprehensive assessment of sea-level rise vulnerability. The District's work had been focused on adjusting Lake Okeechobee's operations using seasonal climate forecasts. For that purpose, one of the District's engineers had initiated a set of climate studies that summarized all the local climate influences that global climate models did 
not take into account. Discussing with one of the District employees, I was told that at the time of the fist Task Force meeting, the agency had not considered climate change in its official research activities, but that some of the work related to the water operations had directed some tangential interest on climate-change research. During the postpresentation discussion of the Task Force meeting, the Task Force members noted that the District, as well as the Planning Council could provide important support to the Task Force activities (CCATF Recordings; March 15, 2007).

During the third meeting (April 19, 2007), the Task Force expanded on its international collaboration. During this meeting, the ICLEI's policy director, Mr. Jim Yienger introduced his agency's Climate Resilient Campaign and invited the Task Force to work on making Miami-Dade County a pilot community in this effort. Miami, along with cities like New York became one of the key communities in this research initiative. This association would later provide the framework and some resources to create the Greenprint plan, Miami-Dade County's strategic plan for climate adaptation actions (CCATF Recordings; April 19, 2007). In addition, ICLEI offered financial support for climate initiatives in 2009 , when the county was facing major economic constrains due to the recession (CCATF Minutes, April 30, 2009).

\section{Forging Coalitions From the Inside the Bureaucracy}

Many, and often some of the most important, coalition building processes are not visible in the Task Force meeting minutes or audio recordings. One such example is the way the Task Force chairman forged crucial coalitions with some of the county commissioners. What is easier to identify, however, is the logic behind building certain coalitions or the results of creating them. For example, in one of the meetings, one Task 
Force member notes that the ability to engage officials from the inside is crucial to the work of the Task Force, as "when dealing with officials, the messenger is more important than the message" (CCATF Minutes, April 19, 2007; page 9). It is clear that these coalitions are built through the existing connection of the Task Force's leaders, such as the case of the early and fruitful alliance with Miami's City Mayor or the latter alliance with the County Manager.

During the April 19, 2007 Task Force meeting, the chairman announced that the County Manager had offered the support of a series of county departments. For example, the County's Aviation, Seaport, Emergency Management, Transit, Public Works, Capital Improvements, Housing, Planning and Zoning, Water and Sewer, Environmental Resource Management, Solid Waste, Budget and General Services Administration departments, were all invited by the County Manger to serve as liaisons between the Task Force and the County (Appendix II CCATF Initial Report; Letter to the County Commissioners July 10 2007, page 4). Among these, the Water and Sewer Department played a particularly active role in the Task Force.

Networking and strategic membership expansion continued for the entire duration of the Task Force meetings, and Task Force members often used their personal connections and professional activities to advance Task Force goals. For example, during the January 11, 2008 meeting, Chairman Ruvin noted that he had been appointed to the Florida Energy Commission (FEC) and that he thought that this appointment would be the perfect vehicle to encourage Legislature to mandate all local governments to engage in greenhouse gas reduction and adaptation strategies (Minutes, January 11, 2008:1). In the same meeting, the chair of the Economic and Social Health Committee (one of the 
four Task Force subcommittees) noted that political candidates would be joining him in a fishing tournament he was organizing and that he was going to use that opportunity to address them on what they thought about climate change (Minutes, January 11, 2008:9). Furthermore, committee leaders and members became important liaisons to regional, state and local agencies. In Figure 1, colors were used to note some of the key alliances that were forged in this way at local/regional (orange), state (cyan) and national (blue) administrative levels. In brown I signal some of the few connections made with the private sector.

State agencies such as the Department of Environmental Resource Management (DERM), The District (SFWMD) or federal agencies like The Everglades National Park (ENP), and county agencies the Miami Dade County Water and Sewer Department (MDWSD) have traditionally played key roles in determining the content and direction of the socio-ecological life of the region. The District, for example, regulates the water consumption of the entire region and has been involved with DERM and ENP in providing the regulatory expertise for the expansion of the urban development boundary in areas that have not been developed before. Also, as I discussed earlier, the county Water and Sewer department is crucial for the county's electorate. Therefore, collaborations with this department were very important for the success of mainstreaming climate change into the county's planning operations. Coalition building capitalized largely on the professional networks that its members had. In Figure 2, I show that some of the key members of the Task Force were themselves affiliated with some key institutions. On April 30, 2009, the Intergovernmental Affairs Committee partnered with the League of Cities, a state coalition of elected municipal officials, to develop and 
administer a survey to all key municipal elected officials and staff (page 5). The main objective of this survey was to gauge the level of interest and knowledge for climatechange adaptation. The analysis of this survey showed that at municipal and city levels there were few incentives to implement climate adaptation.

Figure 2. The Task Force's Leadership Affiliations

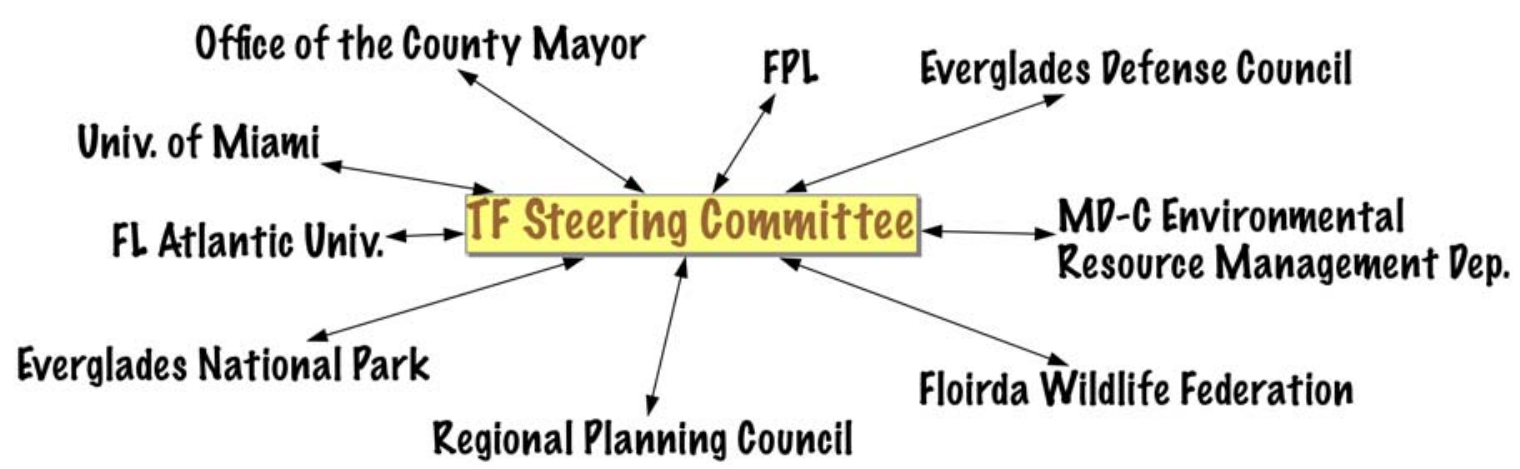

In conclusion, the association and collaboration with different agencies allowed the Task Force members to gain easy access to pertinent information and possible funding avenues. For example, at one of the Task Force meetings, Commissioner Sorensen's aide clarified the reason one of the recommendations proposed by the Task Force had not been adopted. He noted that the existing Florida Building Code, as it permits to Miami-Dade County, had some internal conflicts that needed to be resolved. He also pointed out that each municipality had a building code official that was familiar with solar applications and that the County's Building Code Compliance Office (BCCO) was working to provide guidance (Task Force Meeting Minutes, Feb 20, 2009, page 8). The Task Force members asked to be informed on future meetings of the BCCO, implying a need to be a part of these meetings and discuss the recommendation relevance directly with this office. During the same meeting, the Task Force's Vice-chair 
announced that he was elected as the new Chair of the Florida Energy Commission. He continued by providing information on existing grants, and other pertinent work and noted the potential support that the agency could provide in moving the Task Force's recommendations into legislative action. Also, following his presentation, the Assistant Director of the Office of Intergovernmental Affairs discussed the funding available for climate mitigation and offered to create a matrix of potential uses of federal funding for climate-change efforts.

In this section I focused on detailing the coalition building processes in which Task Force members engaged. The social movement literature conceptualizes these activities as a part of larger bureaucratization processes, when the social movement gains certain stability and a more formal organizational structure. In the case of the Task Force, these coalitions acted to stabilize and strengthen ideas about the needs and abilities of implementing climate-change adaptation within the County bureaucracy. For these purposes the Task Force members expanded its research and work capabilities and worked on gaining the support of different county departments. In the following section, I turn the focus towards the moments when the Task Force members stepped out of the bounds defined by their position within an advisory body to try to make their ideals a part of the county's legal mandates. I borrow a social movement concept, mainstreaming, to analyze this process.

\section{Mainstreaming Climate Change}

Brainstorming, conceptualizing, and refining recommendations on how the county administration should respond to the potential impacts of climate change was a key Task Force objective, as well as an important part of mainstreaming climate change within the 
county administrative tasks. The Task Force authored over 60 climate-change recommendations. While most of the sub-committees focused on climate-change adaptation strategies, one sub-committee focused strictly on mitigation. The mitigation component of the final set of recommendations put forth by the Task Force was one of the most researched and well defined. This was largely due to the fact that climatechange mitigation had been a part of the county's work for ten years prior to the work of the Task Force.

Overall, the recommendations were designed both through an assessment of climate-change/sea-level rise vulnerabilities, as well as direct and indirect feedback from the county's leadership. In this section, I focus on presenting the discussions and actions that resulted in the interaction with the supervising entity, Miami-Dade County's Board of County Commissioners (BCC). This particular interaction shows how mainstreaming is neither a simple and logical process, nor a direct result of assessing needs and designing logical action items. Rather, the interaction I refer to is complex, messy and at times quite unpredictable. One specifically telling example is the Steering Committee discussion that ensued after the presentation of the first set of recommendations to the Board of County Commissioners.

Two years into its existence, the Task Force members faced a most confusing and stymieing episode. The November 14, 2008 Steering Committee meeting opened up in 
the middle of a seemingly informal conversation. The Task Force chairman ${ }^{48}$ expressed confusion, followed up by disappointment and a promise of confrontation:

I had a serious meeting with her and George and at this point we need to think at other alternatives because we cannot allow her to just (undistinguishable).... and I don't know why she would want to do that. The only thing that I've concluded is that she might have some jealousies or some angst; that she does not want anyone to do something that she might want to do, but she is not sure whether she wants to do it or not.

... I'm going to confront her. I'm going to say: look! I'm going to go to the Mayor!

I thought we had her on our side, but somewhere along the line I think she doesn't want anybody else to do something that she is not sure that she wants to do. (Audio

Recording, November 14, 2008, minute 2).

Even though "her" name is not mentioned, it seems clear, based on previous discussions, that the source of disappointment is Commissioner Seijas. As I mentioned earlier, Commissioner Seijas was instrumental in creation of the Task Force and pledged her

${ }^{48}$ As a participant in the last two Task Force meetings, as well as in numerous climate change summits, workshops and conferences, I easily recognize the voices of some of the most preeminent Task Force members, particularly its chairman. 
support for the advisory body at the end of the first year of its existence (June 6, 2007 audio recording). The reason that her sudden retreat of support seemed so damaging to the work of the Task Force is because its chairman thought he had reached a tacit agreement with a key county commissioner. As the Chairman notes in the meeting, he had targeted Commissioner Seijas, because "she knows very well how to make things happen”. With her support for the climate-change adaptation agenda, the Chairman thought that the Task Force was a mere formality required by the county bureaucracy. Chairman Ruvin's disbelief is likely a result of his sudden realization the work of the Task Force was not a done deal, but rather a process that is new and confusing. As I discussed in the introduction, the Task Force is an entity with a mixed membership and that, even though has some county administration staff it does nit represent the county administration. Given the murky and confusing position of this advisory body, it is not surprising that confusion ensued. This is also clear in the early meetings of the Task Force when individuals present at the meetings ${ }^{49}$ addressed the Task Force using an activist rhetoric forcing the Chairman to emphasize several times that the Task Force's work was not political. Discussing this topic with one of the former Task Force members (Interviews; October 3, 2013), I was told that indeed it took several meetings before everybody present understood that even through the Task Force was chaired by county/state staff and officials it was not a part of the county administration.

As the discussions during the November 14, 2008 meeting continued, three mainstreaming obstacles became clear. First, the Task Force members became aware that

\footnotetext{
${ }^{49}$ Based on the audio recordings it is not evident whether those individuals were appointed Task Force members or invited volunteers.
} 
there were certain opaque processes at the county management level they had not been aware of. For example, one of the members, noted:

You can tell that there are some politics that's being played (Audio Recording, November 14, 2008; minute 7).

Second, the Task Force members were made aware of the existence of other powerful interests that had not been infiltrated by the networking work done in the first few years of the Task Force. Responding to one of the member's question regarding whether there are other recommendations that were perceived as a threat to other interests, one of the members responded:

Well obviously the one recommendation related to the taxicab recommendation. The industry has reacted negatively to that and that's an industry that's always been important to commissioner's re-elections (Task Force Audio Recording November 14, 2008; minute 9).

Third, while the Task Force had initiated a series of projects with a number of county agencies, there appeared to be significant confusion surrounding decisions about moving forward with implementing recommendations, previously approved by the County Commissioners. Much of the rest of one and a half hour is spent trying to understand what could be the possible avenue for implementing the approved recommendations, and who or what county office should be approached to obtain guidance on this matter.

At the conclusion of the November 14 meeting, the members invited Commissioner Seijas' policy advisor to be an official member of the Intergovernmental Affairs Committee. The Task Force Steering Committee believed that his participation, and 
possibly the participation of other commissioners or commissioner representatives, would ensure potential problems with the recommendations would be discussed possibly even amended before their official submission to the County Commission. Also, the Steering Committee members discussed the possibility of involving the regional water management agency (The District). Task Force members considered that the District's involvement was very important. Several of them noted that the District had the expertise and regulatory power necessary to implement some of the approved recommendations.

While these two goals for increasing the Commissioners' approval were pursued successfully, there is little discussion about forging coalitions with those industries that were unsupportive of the Task Force's mission, such as the transportation or real estate industry, which were clearly targeted in the proposed recommendations. A lack of involvement from private industries is noted during the public comment section of the June 24, 2009 Steering Committee meeting. During this meeting, a representative of the Builders Association of South Florida expressed concern that "no representative of the commercial builders, residential, and industrial industries were involved in the advisory board of the Smart Growth Partnership" (page 11). The Smart Growth Partnership was an alliance of local city planning departments with which the Task Force was building supportive relations. The mismatch in goals with the large real estate industry becomes abundantly clear for the Task Force members during one of the Board of County Commissioners legislative session. One Task Force member noted indignantly that not long after the Task Force recommendation on limiting development west of the Urban Development Boundary (UDB) was presented, the commissioners approved the move of the UDB westward at the request of this industry (Minutes, November 13 2009: 2). 
The Task Force members did not seem to have forged coalitions with other keylocal industries, such as the taxicab industry. This was evident when one of individuals present at the November 13, 2009 meeting, mentioned that the recommendation to support the acquisition of high efficiency vehicles for the taxicab industry did not stand a chance to be adopted into law. Task Force members found that an Advisory Committee, which apparently enjoyed a veto authority privilege, represented the local taxicab industry at the county administrative level. The industry used this privilege to dismiss the Task Force recommendation (Minutes, November 13, 2009: 3). During the October 9 , 2009 Science Committee meeting the Office of Sustainability director, noted that many of the Task Force recommendations were likely not moving forward because of the lack of focus on comprehensive economic planning; in addition he noted the Task Force recommendations were too vague (page 3 ).

Amending the Task Force Work

As noted earlier, the first change in the Task Force's focus was toward strengthening relationships with the County leadership. At the beginning of the third year of its activities, the Task Force received some clarity on the lack of support received from Commissioner Seijas and had managed to forge a close alliance with a new County Commissioner.

At the February 20, 2009 Task Force meeting (three months after the November 8, 2008 Steering Committee meeting discussed above), Chairman Ruvin announced that the Government Operations and Environment (GOE) County Committee would no longer oversee the operations of the Task Force. This change resulted from Commissioner Seijas being replaced from her chairing functions in this committee. Instead, he announced that 
the Budget, Planning and Sustainability Committee would become the County's overseeing entity, and its chair, Commissioner Sorensen was planning to be involved in the Task Force. Commissioner Seijas remained represented in the Task Force through her Senior Policy Advisors (Audio Recording of Task Force meeting, February 20, 2009).

During the following Steering Committee meeting (June 24 2009), Chairman Ruvin noted that that this change in leadership affected Commissioner's Seijas ability to help the Task Force with recommendation approval and implementation. Later in the same meeting the Office of Sustainability manager confirmed an appointment between him, the Task Force chairman and the County Manager's Assistant to discuss the procedure for implementing the approved recommendations (CCATF Meeting Minutes, June 242009 , page 9).

Sunset-ing ${ }^{50}$ the Task Force

By August 2010, the Task Force was wrapping up its activities. While the proposed steps to amend the work of the Task Force have clearly identified some of the major weaknesses of the mainstreaming work of this advisory committee, the remaining meeting minutes and audio recordings available for the Task Force do not offer insights into the extent to which these amending actions were pursued. However, many of the members of the Task Force remained involved with climate-change adaptation planning. The Southeast Florida Regional Climate Compact (SEFRCC; the "Climate Compact"

${ }^{50}$ Sunset is a legal term used in the ordinance that established the Task Force; it refers to the process of ending the Task Force operations; this process includes a survey of the Task Force members to assess the necessity to continue or not the activities of the advisory board. 
hereafter) took over much of the work of the Task Force when its activities ended; ${ }^{51}$ much of the administrative support staff that the Task Force had during the years of its functioning, became involved with the activities of the Climate Compact. The Climate Compact is today a unique regional coalition of local governments able to draw on numerous economic and intellectual resources. At the same time, some of its members continued on a different path.

During the last meeting of the Task Force (just before the committee ended its activities) on December 12, 2010, Dr. Harold Wanless distributed copies of an application for a seminar he was going to lead over the course of four consecutive Saturdays, entitled "Empowering Capable Climate Change Communicators". The seminar brochure noted that the goal of the seminar was to "make the participants sufficiently conversant with the topics and with adequate materials that they begin to effectively educate others" (Minutes, December 12, 2010, Exhibit 8:1). When I asked what were the requirements for participation, I was told that anyone willing to spend eight hours each Saturday, learning about climate change was welcome.

During four Saturdays I listened to presentations that detailed the science of climate change as well as the numerous impacts it would have in South Florida and in the world in general. During the first Saturday one presenter caught my attention in particular. Carolyn Lewis, a charismatic woman, was going to teach us to become "empowered" climate communicators. She had done this before with school children and

51 The Climate Compact was first envisioned under Natural System's recommendation D10. This recommendation was approved into law in 2009. Its goal was to create a coalition between the four Southeast Florida counties (Broward, Dade, Palm Beach and Monroe) to develop "joint policy positions and legislative policy statements, as well as ... an action plan" (Minutes, April 26, 2010; Exhibit 1:18). 
she was eager to do this again with anyone who was willing. She proudly announced that she had just founded the CLEO Institute, which stands for Climate Leadership Engagement Opportunities, and that her mission was to inform and engage the public into taking action on critical climate and environmental issues.

Carolyn Lewis and the CLEO Institute are today well known within and beyond Miami’s activist groups. CLEO and some other former Task Force members, like Dr. Harold Wanless form a coalition of people that do not shy away from discussing the impacts of glacier melting, ocean acidification, expansion, and strategic coastal retreats in alarmist terms. While people like Dr. Wanless and others distanced themselves from the bureaucratic arena of climate-change adaptation planning, activism and often individual legal action ${ }^{52}$ provide their main avenues for mainstreaming the climate-change knowledge that the county's bureaucracy is not yet ready to incorporate.

\section{Conclusions}

My research on the emergence and shape that climate-change concerns took in Miami reveals that the Task Force activities catalyzed attention within the county bureaucracy and effectively began an important process of institutional transformation. The Task Force members focused on forging social coalitions, an activity that social movement scholarship attributes to a third evolutionary stage in the evolution of a social movement, called bureaucratization. As the activities of the Task Force progressed, and its membership base expanded, Task Force members capitalized on the coalitions they formed to try to begin the process of implementing some of the climate-change

\footnotetext{
${ }^{52}$ I was told during interviews with two former Task Force members about three such legal actions; Waterkeeper vs MDWS is the most famous one.
} 
mitigation and adaptation recommendations they had drafted. This process was fraught with difficulties, many of which can be explained broadly by Miami's development history as detailed in the previous chapter. However, responding to this opposition, some of its members exited the bureaucratic arena and developed new avenues to mainstream climate change into the region's bureaucracy. At the same time, the work of the Task Force became incorporated in a larger regional climate-change adaptation effort and is today a part of expansive climate-change governance. 


\section{References}

Benzie, Magnus, Alex Harvey, and Karen Miller. 2011. "Adaptation in UK Cities: Heading in the Right Direction?" In Resilient Cities: Cities a Nd Adaptation to Climate Change Proceedings of the Global Forum 2010, edited by Konrad Otto-Zimmermann and Monika Zimmermann, 1st ed., 231-41.

Blake, Nelson Manfred, Christopher F. Meindl, Steven Noll, and David Tegeder. 2010. Land into Water--Water into Land: A History of Water Management in Florida. 2nd ed. Gainesville: University Press Of Florida.

Carter, Luther J., and Resources for the Future. 1975. The Florida Experience : Land and Water Policy in a Growth State. J. Floyd Monk Collection. Baltimore: Published for Resources for the Future by the Johns Hopkins University Press.

Crate A. Susan. 2011. "Climate and Culture: Anthropology in the Era of Contemporary Climate Change.” Annual Review of Anthropology 40: 175-94.

Dash, Nicole, and Betty Hearn Morrow. 2000. "Return Delays and Evacuation Order Compliance: : The Case of Hurricane Georges and the Florida Keys." Global Environmental Change Part B: Environmental Hazards 2 (3): 119-28. doi:doi: DOI: 10.1016/S1464-2867(01)00008-0.

Edelman, Marc. 2001. "Social Movements: Changing Paradigms and Forms of Politics." Annual Review of Anthropology 30 (January): 285.

Favela, Miho. 2015a. "Despite Latin Ameirca Slowdown, Miami Still Top Foreign Buyer Market." World Property Journal, April 14. http://www.worldpropertyjournal.com/realestate-news/united-states/miami-real-estate-news/miami-foreign-property-buyers-report2015-foreign-property-investors-in-miami-brazilians-buying-miami-condos-canadianproperty-buyers-in-florida-2014-miami-international-buyer-survey-9007.php.

Few, Roger; Brown, Katrina ; Tompkins, Emmal. n.d. "Public Participation and Climate Change Adaptation: Avoiding the Illusion of Inclusion.” Climate Policy 7 (1): 46.

Finan, Timothy. 2009. "Storm Warnings: The Role of Anthropology in Adapting to Sea-Level Rise in Southwestern Bangladesh." In Anthropology and Climate Change: From Envounters to Actions, edited by Susan A Crate and Mark Nuttall.

Fiske, Shirley J. 2009. "Global Change Policymaking from Inside the Beltway: Engaging Anthropology." In The Anthropology of Climate Change: From Encounters to Actions, edited by Susan A. Crate and Mark Nuttall. Walnut Creek, CA: Left Coast Press, INC.

Gerrity, Michael. 2012. “After Historic 2008 Crash, Downtown Miami Among Nation's Most Active Residential Marckets in 2012." World Property Channel, March 13. 
http://www.miamidda.com/pdf/3.13.12\%20World\%20Property\%20Channel.\%20After\% 20Historic\%202008\%20Crash,\%20Downtown\%20Miami\%20Among\%20Nation $\% 27 \mathrm{~s} \%$ 20Most $\% 20$ Active $\% 20$ Residential\%20Markets\%20in\%202012.pdf.

Gladwin, Hugh, Betty Hearn Morrow, and Walter Gillis Peacock. 2000. Hurricane Andrew: Ethnicity, Gender, and the Sociology of Disasters. Miami, Fla: International Hurricane Center, Laboratory for Social and Behavioral Research, Florida International University.

Godfrey, Matthew C., Theodore Catton, and United States Army Corps of Engineers. 2011. River of Interests: Water Management in South Florida and the Everglades, 1948-2010. Washington, D.C: Published for the U.S. Army Corps of Engineers, Jacksonville District, by the Government Printing Office. http://purl.fdlp.gov/GPO/gpo29059.

Goodell, Jeff. 2013. “Goodbye, Miami.” Rolling Stone, June 20. http://www.rollingstone.com/politics/news/why-the-city-of-miami-is-doomed-to-drown$\underline{20130620 .}$.

Green, Donna. 2009. "Opal Waters, Rising Seas: How Sociocultural Inequality Reduces Resilience to Climate Change among Indigenous Australians." In Anthropology and Climate Change: From Envounters to Actions, edited by Susan A Crate and Mark Nuttall.

Grundwald, Michael. 2007. The Swamp - The Everglades, Florida, and the Politics of Paradise. Simon and Schuster Paperbacks.

Hollander, Gail. 2005. "The Material and Symbolic Role of the Everglades in U.S. National Politics." Political Geography 24 (4): 449.

McCally, David. 1999. The Everglades : An Environmental History. Florida History and Culture Series. Gainesville: University Press of Florida.

Meyer, Robert. 2014. "How Climate Change Is Fueling the Miami Real Estate Boom." Bloomberg Business, October 20. http://www.bloomberg.com/bw/articles/2014-1020/how-climate-change-is-fueling-the-miami-real-estate-boom.

Morrow, Betty Hearn, and Walter Gillis Peacock. 1997. Hurricane Andrew : Introduction. Miami, Fla: International Hurricane Center, Laboratory for Social and Behavioral Research, Florida International University.

Nicolas Nierenberg; Walter R. Tschinkel ; Victoria J. Tschinkel. 2010. “An Independent Thinker, Willing to Say What He Thought." Nature 466 (7305): 435.

Oliver-Smith, Anthony. 1996. "Anthropological Research on Hazards and Disasters." Annual Review of Anthropology 25: 303-28. 
Oliver-smith, Anthony. 2012. "DEBATING ENVIRONMENTAL MIGRATION: SOCIETY, NATURE AND POPULATION DISPLACEMENT IN CLIMATE CHANGE.” Journal of International Development 24 (8): 1058.

Pristin, Terry. 2013. "Miami Trying to Catch up Real Estate Demand." The Heral Tribune, May 13. http://www.heraldtribune.com/article/20130513/ARTICLE/305139989.

Roger Pielke ; Gwyn Prins ; Steve Rayner; Daniel Sarewitz. 2007. “Climate Change 2007: Lifting the Taboo on Adaptation." Nature 445 (7128): 597.

Sharma, Divya, and Sanjay Tomar. 2010. "Mainstreaming Climate Change Adaptation in Indian Cities." Environment \& Urbanization 22 (2): 451-65.

Tompkins, Forbes, and Christina Deconcini. 2014. "Sea Level Rise and Its Impact on MiamiDade County." World Resources Institute. http://www.wri.org/sites/default/files/sealevelrise_miami_florida_factsheet_final.pdf. 


\section{THE SOCIO-ECOLOGICAL HISTORY OF WATER MANAGEMENT}

\section{Introduction}

In the first part of this dissertation (Chapters 2 and 3) I focused on presenting the contexts and ways in which concerns about the potential impacts of climate change have emerged and been made a part of Miami's socio-political world. In this second section of the dissertation (Chapters 4, 5, and 6) I turn to an analysis of the ways climate change became an object of concern at the District, Miami's regional water management agency. As I discussed in the introduction of this dissertation, the District is undergoing one of the most challenging financial transitions in its history. Climate-change concerns, while already politically contentious, are raised in a context of ever-shrinking research budgets and increased operational complexity, as I show in more detail in the following chapters. In this chapter, however, I argue that the District's decision-making processes are shaped by a long and often contentious history of interacting with a series of groups of special interest. In this chapter I present this history and show how these groups have formed stable, yet often unequal positions, within the region's water and environmental planning institutional structures.

\section{Special Interest Groups in South Florida}

Critical studies of environmental management show that decisions are often shaped by a political struggle between diverse and unequally positioned social actors (Peet and Watts 2004; Neumann 2005). Social studies of science, particularly research on scientific expertise, have further argued that these unequal positions are sometimes reflected in state decision-making processes. Scientific expertise is used in this context to legitimate decisions that favor the needs of the most powerful actors (Mitchell 2002). 
Expert decision making is revealed in this way as a power-laden practice. More recently, researchers have documented that the public has increasingly contested these expert forms of decision making and as a result the political format of decision making has changed (Latour 2010). More precisely, expert agencies have increasingly adopted policies that allow the public to be a part of scientific data collection and analysis (Whatmore 2003). This expansion has certainly happened at the District.

Sifting through agency documents, I was intrigued by a brief mention that noted the rules of managing Lake Okeechobee's waters have been discussed and reviewed by a set of knowledgeable-stakeholders (SFWMD 2010,9). The identifiable term knowledgeable-stakeholders was unusual as I had not encountered it elsewhere in the District documents or heard it during the twelve public meetings I had attended. In my interviews, water managers clarified that the District had reorganized itself in the early 2000s to become more inclusive in its decision-making processes, and as a result, certain interest groups accessed more information, and more importantly began participating in numerous District information sessions, meetings and workshops. As a result they became conversant in the science of water management. These were the groups that the District usually favored when feedback was necessary.

Previous research has acknowledged the emergence of collaborative processes between the District and its interest groups in the context of the late 1990s' shift towards adaptive frameworks of governance (Vedwan et al 2008; Dengler 2010). In this chapter I show that in the 1960s two main interest groups used scientific discourse and litigation to shape the content and direction of South Florida's water management. These two practices led to a major transformation in 1972 when the state expanded the prerogatives 
of the Flood Control District (FCD) and created the District. During almost three decades since its existence, the District has changed its relationship with an increasingly diverse set of interest groups, and has opened many of its decision-making processes to the public. Nevertheless, the main protagonists of the 1960s conflict remain very important to this day.

\section{Water Management in South Florida Before 1972}

In a rather unusual exhibit curated by Bruno Latour and Paul Wiebel, entitled after their edited volume "Making Things Public" (2005), the authors discuss the transformative power that both things and people have and argue that oftentimes social groups transform in response to a shift in power and a consequential need to be represented politically. Political representation becomes crucial for the groups permanence in the "assembly of things" (Latour 2005). To illustrate these ideas, the exhibit used several examples. The Maori Tribe exhibit was one such example. This exhibit showed a sequence of images of the flax plant. These images represent the plant in closer and closer shots that go from a field of flax to the microscopic image of the genetic composition of the plant. The flax plant had been an important part of the economic as well as cultural practices of the Maori Tribe and had often served as an identifying Maori commodity. Anita Herle, offering some background on the exhibit, noted that the Maori people felt their spiritual and moral values, as well as their economic rights were threatened by the use of GMO technology on the flax plant. More precisely, even though the GMO flax plant had different qualities compared to the flax plant the Maori Tribe produced, these differences were not visible through a eye and led to confusions between the two. The Maori Tribe efficiently integrated western knowledge 
within their own knowledge-system to be able to change New Zealand's legal and economic context. The Maori patented the flax plant using a genetic analysis that showed the differences between the Maori produced flax plant and the GMO ones.

Zealand's Intellectual Property law is unique in the world precisely to the way the Maori Tribe modified it. This law gives the Maori Tribe exclusive rights over the production and commercialization of the flax plant for manufacturing purposes. ${ }^{53}$

In the following section I show that even though South Florida's water management interest groups have very different social and political standing compared to the Maori Tribe, they too have made use of the scientific discourse to gain political representation during times when shifting societal values threatened their ability to influence the course and direction of water management. South Florida's interest groups have crystalized as water management in South Florida became increasingly complex; more specifically as a result of the massive geo-hydro-engineering projects that took place beginning with the construction of the Herbert Hoover Dike in the 1930s. This project was designed in response to the catastrophic floods that followed the 1926 and 1928 hurricanes.

\section{Water Management after the 1920s Hurricanes}

When the Great Miami Hurricane killed more than 400 people (Blake 1980; Will 1971) in 1926, water management was already at the center of public controversy (Dovell 1948, 426). To respond to criticism, the Everglades Drainage District (the EDD) designed a proposal to ask state officials to fund the construction of an improved dike around Lake

\footnotetext{
${ }^{53}$ For more information see: Susy Frankel. New Zealand Intellectual Property Legislation. http://www.TeAra.govt.nz/en/intellectual-property-law/page-3 (last accessed January 26, 2015).
} 
Okeechobee to insure better flood protection as well as help improve existing drainage projects. The state funded only minor repairs to the collapsed dikes (Grundwald 2007, 190) and in 1928 the Okeechobee Hurricane destroyed much of the water infrastructure built around Lake Okeechobee and left horrifying memories in the minds of those who survived. It was estimated that 2500 people died during the storm (Grundwald 2007, 193). Zora Neale Hurston's (1937) account of the hurricane presents some of the ways this event lived in the memory of those who survived it: water "uprooted them like grass and rushed on after these supposed to be conquerors, rolling the dikes, rolling the houses, rolling the people in the houses along with other timbers." (238)

Lived and perceived as a national disaster, the Okeechobee Hurricane ushered in a new way of experiencing nature, one that was premised on the idea that through major technological intervention the experience of nature would become permanently safe, riskless. The state administration as well as a group of investors in the sugar industry were prominent when they demanded federal support for reconstruction (Blake 1980, 141). As a result, in 1930, President Herbert Hoover authorized the construction of a series of dikes and levees around Lake Okeechobee in response to the previous' decade flood events (USACE 2014). ${ }^{54}$

The construction of the Herbert Hoover Dike marked the beginning of a period of major hydrologic engineering in South Florida. As the fertile floodplain of Lake Okeechobee became less prone to flooding, the agri-business sector flourished (Blake

\footnotetext{
54"Lake Okeechobee and The Okeechobee Waterway". U.S. Army Corps of Engineers South Florida Operations Office. http://web.archive.org/web/20081012182022/http://www.saj.usace.army.mil/sfoo/index.h tml (last accessed on April 6, 2014)
} 
1980; McCalley 1999). It is well known that the $19^{\text {th }}$ and much of the $20^{\text {th }}$ century engineering projects were viewed as avenues of economic progress. South Florida's economic development was dependent on drainage and hydro-engineering projects. However, while some business enterprises profited from these hydro-engineering projects, scientists and citizens opposed them. Robert Gottlieb (1993) analyzing the evolution of environmental conservation ideas in the United States, argued that environmental activism expanded and transformed towards the middle of the $20^{\text {th }}$ century. The health of wildlife, forests, water bodies and everything that encompassed perceptions on wilderness became important beyond elite circles concerned with vanishing game; as a consequence, environmental activism expanded as women and minorities began to play prominent roles within this movement.

The expansion of environmental activism is South Florida is particularly visible in the 1940s, when The Everglades National Park was established. Environmentalists like the famous author of "The Everglades, River of Grass," Marjory Stoneman Douglas (1947) viewed the Park's establishment as a conservation victory (McCally 1999). However, this major victory did not mark the beginning of an era of decreased environmental engineering. On the contrary, the congressional approval of the Central and South Florida Flood Project (the C\&SF) in 1948 completely transformed the region's wild landscape (Light and Dineen 1994), and in doing so it transformed its economy and politics.

\section{The C\&SF Flood Control Project and South Florida's Environmentalism}

In the 1970s, Arthur Marshall, a scientists working with Florida's Wildlife Federation, began examining the environmental issues of South Florida from the 
perspective of systems ecology (Godfrey and Catton 2011). His research on the way deer were impacted by the C\&SF project was supported by prestigious agencies like the Florida Wildlife Federation, and Florida Game and Fresh Water Fish Commission. Marshal discussed the negative impacts of the C\&SF on the Everglades ecology in several meetings of the Special Study Team of South Florida, a group that was formed by the Florida Flood Control District (FCD) ${ }^{55}$ and the Florida Game and Fresh Water Fish Commission (Godfrey and Catton 2011, 92). His study provided much needed scientific proof to previous environmental activist concerns on the impacts that the C\&SF project had on Everglades' water quality, and consequentially the way this affected wildlife (92). In response, Governor Reuben Askew organized a conference to discuss these concerns. Top scholars from regional universities, environmentalists, representatives from Everglades National Park, the Florida Game and Fresh Water Fish Commission, the US Geological Survey and the US Sugar Corporations were invited to think and "design with nature" (Godfrey and Catton 2011, 94). The recommendations drafted during this conference signaled a drastic change in the way the management of water and land was conceptualized. Among these recommendations, notable were those that demanded the creation of an enforceable comprehensive water and land use plan, restoring the Kissimmee marshes, eliminating or treating water before back pumping into Lake Okeechobee from the Everglades Agricultural Area (the EEA), maintaining certain water levels into the Lake, and establishing a gubernatorial board to oversee water quantity and quality (Godfrey and Catton 2011, 95).

\footnotetext{
${ }^{55}$ The FDC is predecessor of today's South Florida Water Management District (SFWMD)
} 
These recommendations received wide political support and were translated into legislative actions by the end of the 1970s. The new laws marked a major shift in the logic of managing water. Materially, this shift is best illustrated by the 1977 institutional re-arrangement when the FDC was expanded and renamed the South Florida Water Management District (SFWMD) or the District. Formed under the Department of Environmental Regulation (FDEP), the District became the most important water management agency in South Florida. In discussions with District employees today, many of them note that it was in this period that the agency diversified substantially. It effectively moved away from singular focuses like water distribution and began coordinating flood protection practices with water supply and distribution while developing an ecosystem research agenda meant to frame all of its practices. These employees also note that the agency's expertise diversified and grew and that many began their careers at the District due to this expansion.

The success with which environmental activism used scientific expertise to attain alignment to state power, severing in this way a long held agriculture-state association, changed the political performance of the sugar industry. The sugar industry, largely established in the flood plain of Lake Okeechobee, had benefited the most from the construction of the C\&SF project (Hollander 2008). Godfrey and Catton $(2012,100)$ note that sugar interest groups intensified their lobbing activities after the 1970s. At the same time, these groups engaged environmental knowledge about the Everglades ecology and contested some of those claims that were not serving their economic interests (Godfrey and Catton 2011,114). Prior to the 1970s, scientific expertise was the domain of experts and expert agencies, like the Florida Wildlife Federation. As Mitchel (2004) shows, 
scientific expertise was a powerful tool for states as it legitimated decisions about the management of common goods, like water and land. In South Florida, as experts and expertise expanded beyond state agencies, water management transformed. Many of the District employees I have interviewed discussed this transformation in relation to the 1988 lawsuit.

\section{U.S. vs. South Florida Water Management District}

In 1988, Dexter Lehtinen, acting US Attorney, sued the state (the District) and the then Florida Department of Environmental Regulation (DER) (today's Department of Environmental Protection) for failure to regulate the water pumps that were allowing agricultural runoff coming from the Everglades Agricultural Area (EAA) to enter the public waters of the state and end up in the federally owned Everglades National Park and the Loxahatchee National Park. Dewitt (1994) argues that even though the lawsuit did not sue directly the sugar industry, it successfully severed the relation between the state and this industry, mainly by bringing public attention to the influence and lack of accountability that this industry had in the region. The lawsuit argued that the state had allowed the sugar industry to pollute public waters with phosphorus as well as other fertilizers. In a marshy ecosystem such as the Everglades, which is sustained by nutrientpoor waters, such pollution led to major ecological imbalances and was threatening the survival of Everglades National Park.

The lawsuit's vilification of the sugar industry, aided by the supportive environmental community, forced it to create a new public/political identity for itself. A federal decree established The Everglades Agricultural Area Environmental Protection District (EAAEPD), which largely represented the interests of the sugar industry (Dewitt 
1994). The EAAEPD had the power to build structures and conduct studies to address environmental issues in the EAA (Dewitt 1994). Expertise helped blur the pure interest based position of the EAA stakeholders and leveraged their interest-based claims. After three years of litigation, numerous delays and controversies, Governor Lawton Chiles pledged to take responsibility for the pollution that the sugar industry had been allowed to create. The sugar industry, however, continued to challenge the scientific claims that informed this final decision (Godfrey and Catton 2012; Dewitt 1994).

\section{$\underline{\text { Lawsuit Consequences }}$}

The execution of the July 1991 settlement agreement of the lawsuit required the District to create a series of programs to improve water quality, including the building of storm water treatment areas and implementation of a regulatory program that required agricultural growers to use best management practices to clean discharges from the EAA (Rizzardi 2001, 18)

However, these requirements were challenged in court multiple times by agricultural groups ${ }^{56}$ first invoking the State of Florida public records laws, ${ }^{57}$ second the District's plan to respond to the requirements of the Consent Decree (the Surface Water Improvement and Management or SWIM $)^{58}$ and the Interim Permits. ${ }^{59}$ Other District

\footnotetext{
${ }^{56}$ For a brief synthesis of these lawsuits see Rizzardi 2001

${ }^{57}$ Florida Sugar Cane League vs. Department of Environmental Regulatiomn. No. 912108 (F1 2 ${ }^{\text {nd }}$ Cir Ct. Sept 20 1991) per curiam affirmed, 606 So. 2d 1267 (Fla. 1st DCA 1992), and Florida Sugar Cane League v. Department of Environmental Regulation, No. 91-2108 (Fla. 2d Cir. Ct. June 5, 19)

${ }^{58}$ Sugar Cane Growers Cooperative of Florida; Roth Farms, Inc.; and Wedgworth Farms, Inc. v. SFWMD, DOAH Case No. 92-3038 (petition filed 4/9/92)
} 
projects challenged by the EAA agricultural interests were related to the implementation of runoff-control practices and the Everglades Nutrient Removal Project. ${ }^{60}$ Event though the EAA agricultural interests were the main litigators, the District's court cases and its enemies multiplied very fast. By the end of 1992, the District was facing over 30 different lawsuits (Rizzardi 2001).

Central to these lawsuits was the Everglades ecological science and the expert language of water management. The diverse interest groups involved in litigation hired consultants and experts to be able to engage the monopolizing western-scientific discourse of water management. Among these groups, the Miccosukee Tribe, who had been complaining about the ecological impacts of the C\&SF for a long time, hired hydrologists and engineers as consultants and produced a document that established water quality standard requirements for the waters entering their territories. The US Environmental Protection Agency (EPA), noting that the criterion proposed by the Tribe was scientifically defensible, validated these standards in $1999 .{ }^{61}$

${ }^{59}$ Florida Sugar Cane League, Inc.; U.S. Sugar Corporation; and New Hope South, Inc. v. SFWMD, DOAH Case No. 92-3039 (petition filed 4/27/92);

${ }^{60}$ Florida Fruit and Vegetable Assn.; Lewis Pope Farms; W.E. Schlechter \& Sons, Inc.; and Hundley Farms, Inc. v. SFWMD, DOAH Case No. 92-3040 (petition filed 4/9/92) and SSugar Cane Growers Cooperative of Florida; Roth Farms, Inc.; and Wedgworth Farms, Inc. v. DER, DOAH Case No. 92-006796 (petition filed 11/12/92); Florida Sugar Cane League, Inc.; U.S. Sugar Corp; and New Hope South, Inc. v. DER, DOAH Case No. 92-006797 (petition filed 11/3/92); Florida Fruit and Vegetable Association v. DER, DOAH Case No. $92-006799$ (petition filed 11/6/92).

${ }^{61}$ Miccosukee Tribe v. U.S., Case No. 95-0533-CIV-DAVIS (Omnibus order, September 11, 1998). Dan Scheidt, Memorandum to Robert McGhee entitled "Numeric phosphorus water quality criterion for the Everglades as adopted by the Miccosukee Tribe of Indians of Florida for Class III-A Waters" (May 20, 1999). 
The District itself changed in response to these lawsuits. Many of my interviewees told me that the District's largely engineer-based expertise expanded to incorporate biologists and environmental scientists. In a first phase, their purpose was to conduct research to better understand what were those phosphorus levels at which flora and fauna in the Everglades would experience imbalances and establish, based on these findings, the numeric criterion that the cleanup would require (Interviews; March 10, 2015).

In discussions with District employees I was told that the agency became a competitive site for applied science, particularly ecology. The importance and quality of research activities conducted here became evident after the 1988 lawsuit, when the phosphorus limits had to be established. Various scientific institutions engaged in research activities. Among these, Richardson et al. (2000) acknowledge the funding support that the Wetland Research Center at the Duke University, received from the Everglades Agricultural Area Environmental Protection District. Also, Florida International University engaged in similar research. The Florida Department of Environmental Protection reviewed these studies and concluded that the District had produced the most reliable data (McCormick et al. 2000). It was unusual, and a great honor, a scientist remembered, when the science produced in a state agency, was considered more reliable than the science produced by two universities (Interviews; March 10 2015).

Litigation continued, however, with the environmental groups and the Miccosukee Tribe, who unsuccessfully challenged the EFA, particularly in its request to 
impose a numeric standard for the accepted levels of phosphorus runoff. However, it achieved relative success in the lawsuit filed together with the environmental agency Friends of the Everglades. Their request to submit the discharges coming from the S-9 Pump Station on Miccosukee Tribe lands to water quality permitting was granted (Rizzardi 2001). Furthermore, the District was challenged by the adoption of two constitutional amendments that targeted the agricultural interests in the EAA. The first, popularly known as the "polluter pays" provision, makes the EAA interest groups responsible for the pollution of water in the protected areas of Everglades, and the second amendment establishes a trust fund for conservation-use purposes in the Everglades (Rizzardi 2001).

In this section I have shown that the scientific discourse of water management was used initially to attain representation within the region's agribusiness-dominated water management. In response to the success of the environmental groups, agribusiness interest groups pursued similar strategies and provoked a decade-long period of legal conflict. The 1988 lawsuit marked a turning point for the management of water in South Florida. On one hand water quality improved significantly in Everglades National Park as well as in other protected areas (Godfrey and Catton 2011; Dewitt 1996). On the other, the District became the target of a series of lawsuits that significantly challenged the District's water-management expertise. As a result, in an attempt to end litigation and improve its public image and authority, the District expanded and diversified its expertise. In the following section I show that not only that the District integrated ecology in its water management concerns, but also expanded decision making to some of its most litigious interest groups. By the end of this period water management became 
a complex governmental and quasi-governmental institutional arrangement (Ogden 2008).

\section{Water Management and the Legacies of the $20^{\text {th }}$ Centuries}

The first eight decades of the $20^{\text {th }}$ century have had two major water management consequences as decision making expanded and extended. These legacies can be observed in at various collaborative decision-makings sites that formed during and after the 1990s.

\section{Collaborative Water Management at The District}

The transition to collaborative water management occurred in the 1990s when the C\&SF Restudy project began. The C\&SF Restudy was a project that assessed the possibility of reversing some of the damaging ecologic impacts that the 1940s C\&SF Flood Control Project had in the region. Governor Lawton Chiles viewed the narrow environmental focus of the Restudy as a possible source of acrimony among the District's most powerful interest groups (Dengler 2007). ${ }^{62}$ To avoid this situation, he created a commission to include those groups that could challenge the Restudy in court, particularly the sugar industry, various environmental agencies, and the Miccosukee and Seminole Tribes (Dengler 2007). This commission, the Governor's Commission for Sustainable South Florida (GCSSF), became the first instance of institutionalized stakeholder water management. One of its missions was to ensure that the Restudy would not negatively impact the uses of water for agricultural as well as other important users (Dengler 2007).

${ }^{62}$ According to Dengler (2007) the most powerful interest groups had the financial ability to challenge the District in court 
Following this model, another District commission was formed. Michael Collins, a former member of the Governing Board, organized the Water Resources Advisory Committee (WRAC). WRAC is made up representatives from various interest groups that meet on a monthly basis to discuss its members' issues, propose solutions, and make requests for scientific research. The commission was dominated by the region's agricultural interests initially, but diversified throughout the years. Some of the WRAC meetings offer a glimpse into the way the first eight decades of the $20^{\text {th }}$ century have complicated water management in South Florida.

\section{Decision Making and Complex Legal Requirements}

Water management is tied by a series of legal requirements imposed by state as well as federal laws. The terms of the Consent Decree, created in the aftermath of the 1988 lawsuit, remain among the most contested subjects. For example, one WRAC member noted:

For the last 40 years when I was on the Board and trying to figure out how to get water in the Florida Bay; the more I looked at it, the more I realized that the difference between what we can achieve, and what we achieve is due to the USA lawsuit [referring to the 1988 lawsuit]. Without it, we could achieve that mixing zone, that complies with the Clean Water Act, that lets you go forward. This is all a problem because of the need to control, and the federal bureaucracy (Michael Collins, WRAC Meeting June 5, 2014). 
In a similar condemnation of the federal involvement, another member, Malcom "Bubba" Wade, argued that the Consent Decree should end so that the State would gain more flexibility in managing water while still being in agreement with the terms of the Clean Water Act, a more feasible federal oversight. The disapproval with the federal involvement is evident in another instance as well, when a sugar industry delegate asked the Governing Board to consider reinforcing old decision-making processes. Arguing against the Army Corps' inflexible position with regards to the water needs in Everglades National Park, Barbara Medema, noted

Historically the District (pause), the State of Florida, had the sovereign right to allocate water for users, be it the natural system or the built environment. The Corp's role was for regulatory releases or flood protection. That line had gotten blurred over time, and I think that your staff and your time would be well spent if you would work with the Corps on following the guidelines that get developed. (Barbara Medema, Sugarcane Growers Cooperative of Florida; WRAC meeting - June 12, 2014)

In the following section I show how the challenging legal context of water management in Southeast Florida is complicated by a complex and evolving ecosystem science.

\section{Everglades' Science}

As I discussed in this chapter, the Everglades ecosystem has been researched and contested since the 1970s. The uncertainties inherent in the management of this complex 
environment make decision-making processes very lengthy as various groups of interests intervene to contest the District's decisions. The experts' work at the District's is often challenging. During the June 6, 2014 Governing Meeting, one of the experts in charge of Lake Okeechobee's operational schedule tried to convince the Board to allow "slight" modifications to the Lake's operational parameters. From his presentation it seemed that he was asking for permission to work on this schedule in a strictly District-expert environment. Or better said, he was trying to avoid bringing this proposal before the WRAC, a largely interest-based advisory committee. The same month's WRAC meeting provided some insights into the reason why such interaction might be undesirable.

One of the first items on the June 5, 2014 WRAC agenda was the "Overview of the Everglades Phosphorus Limits.” This presentation's stated goal was to bring new as well as not so new WRAC members "up to speed" (Temperance Morgan; Division Director, Everglades Policy and Coordination, SFWMD) with the history as well as jargon of this very important stakeholder issue. Such presentation is usually expected to end with clarification questions. In this case however, the presentation seemed to unearth an old can of worms. In a nutshell, some of the EAA interest-group representatives argued that the numeric requirements for the phosphorus cleanup effort were exaggerating the actual Park needs, because the science invoked to establish these requirements (which others noted was the result of a decade-long research) was questionable. In exchange, he argued that data showed that nutrient levels in Everglades National Park were in fact allowing positive ecosystem dynamics. These arguments, when counteracted, were followed by a long critique of the terms of the 1988 lawsuit which established the phosphorus criteria, the federal bureaucratic involvement, and the 
resulting lack of flexibility in the terms of the Consent Decree. For example, Malcom "Bubba" Wade, Vice-President of US Sugar Corporation, began his comments addressing the science problem:

I was there in 1990, when Ron Jones from FIU testified in the Senate as to what the standard should be. He claimed that everybody knows that if you go in the middle of the Everglades in the Shark River Slew and test the water, that the background phosphorus is $10 \mathrm{ppb}$. That was before everybody went to do the science and figured out what the actual standard was. Well, low and behold ten years later, the standard of $10 \mathrm{ppb}$ became the default standard. I would always question the science that was behind that (WRAC notes, June 5, 2014)

Although he is dissatisfied with the use of science in defining the terms of water quality standards, he is requesting further and more detailed research, which he claims will show that the problem of water quality has been solved already. The suggestion is that the EAA should not be held accountable for the ENP's water problems:

But what you really need to look at is the data, the concentration data. What showed up in these geometric means within the WCAs (these are the Water Conservation Areas north of the Park) and in the Park ..., the water quality's gotten better. What you see coming out of the EAA is in the pipe, versus what is in the area. In the pipe 
means that it should be $10 \mathrm{ppb}$ all the way. What you see coming out of the pipes is more, but within a mile or two that $20 \mathrm{ppb}$ becomes $10 \mathrm{ppb}$. This is a mixing zone...

Michael Collins, former Governing Board member and founder of the WRAC made a similar argument. Collins noted that:

There is evidence that the cattail is growing and is not because of the nutrient, but because of the lack of water. The soil is oxidizing. I looked at the data with some of the District scientists and it's popping all over the place. There is a legitimate question, if you're going to look at the productivity. Scientists said 20 years ago the criterion for restoration was quality. There was no numeric standard, but a quality effect, that increased the flora and the fauna. What we got now, 'cause I fly over the Everglades twice a week, is that all the birds are in the conservation areas, because there is not enough water for them in the system. So, there's a question on what the goal is. As long it is about the court, is all about reaching a statutory goal versus something that is functional. And now it is not functional.

Discussions like the one presented above are common at the WRAC meetings. Scientists and representatives of various interest groups engage in scientific debates with ease ("geometric means in the WCA", "mixing zone"). Collins, for example, talks about 
scientific observation, as well as data collection and analysis, "I looked at the data with some District scientists," and "I fly over the Everglades twice a week." Cast in the middle of a WRAC meeting without knowing its member's backgrounds it is hard to know who is a District expert and who is a representing one of the region's groups of interest. It is clear however that water management at the District is complex, and that some the representatives of various interest groups are extremely knowledgeable both in terms of the Everglades science and the District's decision-making history and processes.

\section{Conclusions and Discussion}

I became aware of the importance that the litigious history of water management has during one of the District workshops (Notes, July 23, 2014). The workshop was hosted at the District's headquarters and invited water managers and various scientists. Here, the Miami-Dade Water and Sewer Department (MDWSD) representative discussed the details of a study conducted in collaboration with the US Geological Survey Agency (USGS) to understand the extent to which salt water had advanced in the aquifer. As soon as the presenter gave an overview of the project, she pointed out that the sea-level rise projections that were used were very conservative because that was the only way they could have made the project legally defensible. During my fieldwork, I often heard experts using the phrase "legally-defensible" interchangeably with "defensible-science." Water management's conflictive legal history, as well as the complex state-federal subordinate role, has complicated and restricted institutional research and decisionmaking processes. However, as I show in the following chapters, the District's employees have developed a culture of finding innovative avenues for integrating conflict and managing water despite numerous limitations. 


\section{References}

Blake, Nelson Manfred, Christopher F. Meindl, Steven Noll, and David Tegeder. 2010. Land into Water--Water into Land: A History of Water Management in Florida. 2nd ed. Gainesville: University Press Of Florida.

Braun, Bruce, and Sarah Whatmore. 2010. Political Matter : Technoscience, Democracy, and Public Life. Minneapolis: University of Minnesota Press.

Demeritt, David. 2001. "The Construction of Global Warming and the Politics of Science." Annals of the Association of American Geographers 91 (2): 307.

- 2006. "Science Studies, Climate Change and the Prospects for Constructivist Critique." Economy and Society 35 (3): 453-79. doi:10.1080/03085140600845024.

Dengler, Mary. 2007. "Spaces of Power for Action: Governance of the Everglades Restudy Process (1992-2000).” Political Geography 26 (4): 423.

Dicke, Willemijn. 2004. "Tales of a Successful Memeplex: How the Water Wars in the Everglades Were Changed into a Comprehensive Plan." Knowledge, Technology \& Policy 16 (4): 61.

Doyle, Mary ; Jodrey, Donald E. 2002. "Everglades Restoration: Forging New Law in Allocating Water for the environment.(Florida)." The Environmental Lawyer 8 (2): 255.

"Final Adaptive Protocols for Lake Okeechobee Operations." 2010. South Florida Water Management District (in cooperation with U.S Army Corps of Engineers, Jacksonville District and Florida Department of Envirnmental Protection. Personal MaxQDA (Documents).

Godfrey, Matthew C., Theodore Catton, and United States Army Corps of Engineers. 2011. River of Interests: Water Management in South Florida and the Everglades, 1948-2010. Washington, D.C: Published for the U.S. Army Corps of Engineers, Jacksonville District, by the Government Printing Office. http://purl.fdlp.gov/GPO/gpo29059.

Gottlieb, Robert. 2001. Environmentalism Unbound: Exploring New Pathways for Change. Urban and Industrial Environments. Cambridge, Mass: MIT Press.

Heikkila, Tanya ; Gerlak, Andrea K. 2005. "The Formation of Large-Scale Collaborative Resource Management Institutions: Clarifying the Roles of Stakeholders, Science, and Institutions." Policy Studies Journal 33 (4): 583.

Hollander, Gail M. 2008. Raising Cane in the 'Glades: The Global Sugar Trade and the Transformation of Florida. Chicago: University of Chicago Press. http://www.loc.gov/catdir/enhancements/fy0827/2007035931-b.html. 
Hurston, Zora Neale. 1998. Their Eyes Were Watching God. 1st Perennial Classics ed. New York: Perennial Classics.

John, DeWitt. 1994. Civic Environmentalism : Alternatives to Regulation in States and Communities. Washington, D.C: CQ Press.

Kern, Richard S. director of photography commentator, Richard director of photography Kern, and Odyssey Earth. 2012. The Everglades : River of Grass. [Miami, FL: Odyssey Earth. http://www.odysseyearth.com/videos/the-everglades-river-of-grass/.

Latour, Bruno, and Bruno Petite réflexion sur le culte moderne des dieux faitiches English Latour. 2010. On the Modern Cult of the Factish Gods. Science and Cultural Theory. Durham [NC]; London: Duke University Press.

Latour, Bruno, Peter Weibel, and Peter 1944 or 5- Weibel. 2005. Making Things Public : Atmospheres of Democracy. Cambridge, Mass. : [Karlsruhe, Germany: MIT Press ; ZKM/Center for Art and Media in Karlsruhe.

Li, Tania. 2007. The Will to Improve: Governmentality, Development, and the Practice of Politics. Durham: Duke University Press. http://www.loc.gov/catdir/toc/ecip074/2006035585.html.

Li, Tania Murray. 2005. "Beyond 'the State' and Failed Schemes." American Anthropologist 107 (3): 383.

McCally, David. 1999. The Everglades : An Environmental History. Florida History and Culture Series. Gainesville: University Press of Florida.

McCormick, Paul, Susan Newman, Garry Payne, and ShiLi Miao. 2000. "Ecological Effects of Phosphorus Enrichment in the Everglades - Chapter 3." In Everglades Consolidate Report. South Florida Water Management District.

Mitchell, Timothy, and Inc NetLibrary. 2002. Rule of Experts Egypt, Techno-Politics, Modernity. Berkeley: University of California Press. http://ezproxy.fiu.edu/login?url=http://www.netlibrary.com.ezproxy.fiu.edu/urlapi.asp?ac tion $=$ summary \&v=1\&bookid $=90542$.

Neumann, Roderick P. 2005. Making Political Ecology. Human Geography in the Making. London : New York: Hodder Arnold; Distributed in the United States of America by Oxford University Press Inc.

Ogden, Laura. 2008. "The Everglades Ecosystem and the Politics of Nature." American Anthropologist 110 (1): 21. 
2011. Swamplife: People, Gators, and Mangroves Entangled in the Everglades. Minneapolis: University of Minnesota Press.

Peet, Richard, Michael Watts, and Michael Watts. 1996. Liberation Ecologies : Environment, Development, Social Movements. London; New York: Routledge.

Pryke, Michael, Gillian Rose, and Sarah Whatmore. 2003. Using Social Theory: Thinking through Research. Thousand Oaks, Calif: SAGE in Association with the Open University.

Rizzardi, Keith. 2001. "Translating Science into Law: Phosphorus Standards in the Everglades." Land Use and Environmental Law 17 (1).

Simmons, Glen, and Laura Ogden. 1998. Gladesmen : Gator Hunters, Moonshiners, and Skiffers. Florida History and Culture Series. Gainesville: University Press of Florida.

Swyngedouw, Erik. 2011. "Depoliticized Environments: The End of Nature, Climate Change and the Post-Political Condition." Royal Institute of Philosophy Supplement 69 (October): 253.

Vedwan, Neeraj ; Ahmad, Sajjad ; Miralles-Wilhelm, Fernando ; Broad, Kenneth ; Letson, David ; Podesta, Guillermo. 2008. "Institutional Evolution in Lake Okeechobee Management in Florida: Characteristics, Impacts, and Limitations." Water Resources Management 22 (6): 699. 


\section{UNCERTAIN CLIMATES}

\section{Introduction}

"No way back"... "the damage is done," proclaimed John Englander, author of "High Tide on Main Street," as he addressed an approving audience during the Sea Level Rise Symposium organized by the Marshall Foundation (Notes; July 26, 2013).

Englander was referring to the massive transformation of South Florida's geo-hydrology that took place primarily at the beginning of the $20^{\text {th }}$ century and now complicates the ability to adapt to the effects of sea level rise.

Perhaps no other place exists where the phrase "no way back" comes alive more than in the operations room at the headquarters of the District. As I stood in front of this awe-inspiring room, also known as "the aquarium" to the District's employees, I could not help but to feel I have been given a glimpse into the laboratory details of a technology dependent world. The aquarium is a few square feet of office space surrounded by glass windows. The room is filled with computers displaying real-time water flow data, modeling scenarios, some satellite images of the atmospheric conditions, and large TV monitors channeling the latest local news and weather reports. Parameters set forth in this office space seem to direct every inch of water in South Florida.

The aquarium's continuous stream of information, urgency of data, and highstakes of "getting the water right" reminded me of famous depictions of the stock exchange room at the World Trade Center. ${ }^{63}$

63 "Getting the water right" is a phrase often used when discussing Everglades Restoration. It refers to restoring the historic flow of water that formed a slow-moving flow from Lake Okeechobee to Florida Bay. In this context I expand the use of this 
One water operations manager describes his work:

The rainwater that comes out as runoff goes through this constructed wetlands. Those constructed wetlands are designed to carry, to take care of at least three-fourth inches in general of rainfall in the basin. ... Then the water that's pumped into the distribution canal is then controlled by gates and released into each cell. These gates have some settings that will help them to automatically control the stages.... we don't want the water to go above 13.5 .... so when it is 13,5 it opens, when it goes down to 12.5 , it closes. ... so this is set up and the gate automatically operates following this criteria. (Participant Observation Digital Recording; July 24, 2013).

Though complex, the water manager's description presents a process that has been figured out, nothing more than a simple routine for the engineer who knows what to do when a certain informational input is received. However, this description does little justice to the numerous uncertainties that decision-makers have to weigh every day. These uncertainties are largely related to the climate's "chaotic dynamics" and the fact that even a "small difference in initial states, can eventually lead to large differences in

phrase to the day-to-day operations the District as these are often overshadowed by the more notorious Comprehensive Everglades Restoration Project (CERP) 
the atmosphere's behavior" (SFWMD 2015 ${ }^{64}$ ). Uncertainty lies at the core of climatechange politics. The national-level discourse is well known; it has often served to infuse climate change adaptation discourse with a can't do type of politics. In the previous chapter I discussed some of the historical legacies that have transformed and shaped the District and which I argued continue to be important decision-maker factors. In this chapter I turn to the present and show some of the District's challenges today and how decision making takes place. During the course of my research I have learned that the District has to tackle many uncertainties in their day-to-day and longer-term operations. The core mission of the agency is to ensure there is enough water to supply its numerous and diverse users. Unfortunately, the agency's ability to fulfill all its goals depends largely on extreme rainfall variations. Because these conditions are difficult to fine tune so users do not suffer from water shortages, checks and balances exist. The Army Corps of Engineers, which is a major decision-maker in South Florida's water management, can overturn the District's decisions. In addition, employees at the District tell me since the late 1970s and particularly in the 1990s the agency has to ensure the sustainable management of the many ecological systems that have formed in these watery lands. All of these factors converge to create an extremely difficult decision making context.

The District places a strong emphasis on minimizing the risks associated with decisions that have uncertain results. To do so, researchers have focused on perfecting numeric models, analyzing past patters of rainfall behavior, anticipating the effects of global climate models on the region, and building complex decision making trees that

${ }^{64} \mathrm{http}: / /$ www.sfwmd.gov/portal/page/portal/xweb\%20\%20release \%202/operational\%20planning (retrieved May 14, 2015) 
offer solutions to a variety of possible situations. More recently, the agency incorporated the principles of adaptive management. Adaptive management has been developed from an understanding that socio-ecological systems are dynamic and therefore their management involves a continuous learning and adjusting of decision making. All of these principles embrace, in theory, uncertainty and acknowledge that decision making in these contexts also has to rely on a degree of professional intuition.

\section{The District's Impossible Mission}

Water managers at the District have an impossible mission: managing rain. Forecasting rainfall variation more than two weeks in advance is difficult. However, water managers often need to take decisions months ahead. South Florida's subtropical climate and its numerous local influences make this job even more difficult. In addition, the region's hydrology has been continuously modified in the last century and has led to the creation of a series of new ecosystems that have to be carefully considered whenever a decision about water is made. Water managers have to keep in mind three major aspects every time they take a decision: flood protection safety, water supply for all users in the region, and the ecosystem health. Generally, but particularly since 2008 when a study revealed that Lake Okeechobee's levee had structural vulnerabilities, flood protection has priority.

\section{At "the Aquarium"}

Managing rain starts at "the aquarium". Here two meteorologists provide the dayto-day rainfall forecasts to hydrologists and engineers in charge of moving water throughout the system. One of my first experiences at the District began with a visit and 
discussion with the meteorologists and engineers working in "the aquarium". Asked about their work and how it relates to water management, one meteorologist noted ...the water is going to fall, and that's the strategy they

have during the wet season. During the dry season it's more of water delivery (FCE Operations Division Tour Participant Observation Digital Recording; July 24, 2013). While waiting for rain to fall does not seem like much of a strategy, it does not quite capture the work of water management at the District. It does however point to an expectation that while there is variation in the rainfall patterns these are within a certain expected spectrum. The tour of the aquarium continued with a discussion that focused on the forecasting process and difficulties followed by an explanation of data sources and meteorologist training. The meteorologists noted that their work is more intense during the wet season because they have to provide forecasts more often and also because the uncertainties are greater than during the dry season. A large part of their work is determining what data to focus on. Global atmospheric models fed by different satellites provide an enormous amount of information that needs to be carefully assessed and selected. One meteorologist explains

During the summer, there's a lot more subtlety that goes on with the atmosphere so, you're kinda' playing detective each day, because the upper levels and lower levels, just move at different speeds and different directions. ... and the models do a pretty horrible job on it because they're not really geared to understand a tropical or subtropical 
environment (FCE Operations Division Tour - Participant

Observation Digital Recording; July 24, 2013).

They also explained that the weather channel or other sources of meteorological prediction are not geared to assess rainfall patterns and specific locations. However, this information is crucial. As District forecasters, they strive to provide rainfall averages as well as potential locations and specific quantities for these locations. One of these forecasters explains that according to rainfall records from 1932, the District can expect from August to November an average of up to two inches of rain:

... and two inches of rain are huge. I mean those are problematic for water managers. There's a lot of water that falls, and they have to take care of. When you have the storage for it, it's great. But if you don't have the storage for it it's not so cool (FCE Operations Division Tour Participant Observation Digital Recording; July 24, 2013). Managing water in South Florida depends on a subtropical climate with two extreme rainfall seasons. During the wet season (May to October), the region receives approximately 60 inches of rain, about three quarters of the average annual rainfall. In addition, the region is highly susceptible to unpredictable short-lived but high-intensity tropical storms. Rainfall variability is particularly difficult to manage here due to the limited storage capacity that such a developed area has.

\section{Okeechobee: Lake and Reservoir}

Lake Okeechobee is a key element in South Florida's water management. Its waters form a connective node between the hydrology of north, east, and west and 
influence the quantity and quality of water to the south. The District's managerial reach is defined by Lake Okeechobee's watershed boundaries. According to the agency's statistics, these include 8.1 million people and their diverse activities making the District one of the largest regional water management systems in the world. The stakes of water management here are high. The operational manual of the Lake reads

Lake Okeechobee is a key component of the Central and Southern Florida Project for Flood Control and other Purposes (C\&SF Project) as well as the central feature of an interconnected regional aquatic ecosystem. As a result, its operation affects a range of environmental and economic issues. Operations of the lake should strive to accommodate and balance numerous and sometimes conflicting project purposes (SFWMD 2010, 1).

Pre-development excess rainfall during the wet season flowed from Lake Okeechobee south and then was retained between two coastal ridges that border the peninsula to the east and west in a bowl-like, sixty mile-wide marshy valley. Today, this water is directed to the Southwest and Southeast through narrow, rapid channels. It is estimated that the storage capacity that the bowl-like valley as well as the lake surface offered the region before drainage has been cut in half (Light and Dineen 1994). This has led to extremes. During the wet season the region is saturated with water, and water managers have to release water pressures on the Lake's dikes via dumping large quantities in the ocean. During the dry season, the reduced reserve of water can lead to water shortages. In the words of a water engineer 
Well, take Lake Okeechobee, that circular area right there is now constrained by a levee. So, if you go back, there's a survey from 1850s, Colonel Ivey's survey ... .so that picture there represents almost 1200 square miles, historic. Now, it's confined to 730 . That means the same amount of water, if it can't expand, then it can only go up and down. Well, up and down it's a problem because of the Herbert Hoover Dike. If there's a levee safety issue, you have to start moving that water before it gets up to a point that constitutes a hazard (FCE Operations Division Tour; Participant Observation Digital Recording; July 24, 2013).

Water managers have been struggling with this water imbalance for decades. However, introducing seasonal climate forecasts with water management operations has only been part of the District's practices since the beginning of the 2000s (Interviews; April 24, 2014). Several employees proudly told me that the District was the first water management agency in the country to integrate climate predictions with water management practices. Focusing on the ways water had to move in or out of Lake Okeechobee, researchers looked at historic patterns of rain and global climate influences to paint a picture of day-to-day expectations as well as possible seasonal patterns. In addition, rain gauges installed at key hydrologic junctions provide a more accurate measure of water levels at different location in the system. However, even with these best estimates, a socio-ecological hierarchy of this expansively engineered hydrology complicates water management. 


\section{Ecological Hierarchies}

“These are living systems,” one ecologist tells me (Interviews; March 10, 2015). South of Lake Okeechobee there are four major categories of land: agricultural lands, water conservation lands which filter water that goes into the Everglades National Park; tribal lands, and finally urban lands on the south-east coast. Each of these requires certain water levels to remain sustainable, but those that are particularly sensitive to water fluctuations are the conservation areas and park requirements. Even small fluctuations of water endanger wildlife here. If water levels in Lake Okeechobee have reached levels that are problematic for levee safety, water has to be moved out of the Lake. Water managers today have three possibilities for releasing water from the lake: releases to the west in the Caloosahatchee estuary, to the east in the Saint Lucie estuaries, or to the south into the water conservation areas and then Everglades National Park. Before deciding on which releases are least damaging water managers look at the historic records. Records indicate the maximum water level tolerable to the region's wildlife. Other socio-ecological factors intervene by giving hierarchical ratings to these areas such as nutrient loads in the water, water velocity that wildlife can sustain, and survival water levels of the Lake's wildlife

itself. Above all, these ecological hierarchies are constantly negotiated and challenged by different groups of interests. All of these contribute to an extremely difficult decision making environment. Nevertheless, water managers have to navigate all these hierarchies and hope that their decisions will have more positive effects than negative:

They can't let that slow them down in getting the information out, because for us, no decision is still a decision .... It's kind of' like an iceberg or a glacier: it's moving at its own 
momentum and it's very difficult as a water manager to gain control of it, and start getting it to turn the right way (FCE Operations Division Tour - Participant Observation Digital Recording; July 24, 2013).

The uncertainty inherent in rainfall variation as well as the diverse and often conflictive purposes that Lake Okeechobee's waters has, are at the core of the water manager's struggle. The feeling that these are almost life or death issues (like icebergs) offer water managers the entitlement they need to take decisions. However, water managers feel a certain frustration with the public and media as they feel their conundrums are not well understood. A water manager noted,

It is kind of a constant challenge. There is a mindset that the organization has to deal with the short term challenges, but also keeps kind of the larger scale either spatial or temporal picture in play to try to balance the overall performance of this system, not knowing what the future brings in terms of rainfall or hurricanes or water shortage (Interviews; June 10 2014)

At the end of our tour of the aquarium, the chief of the Water Bureau also emphasized the following,

So, the first thing you're learning from the meteorologists: number one: we don't manufacture water, we're moving it through a corridor that's been greatly diminished spatially (Participant Observation Digital Recording, July 24, 2013). 
Although often heard, the statement above is meant to anticipate public criticism. Managing water in South Florida is extremely difficult precisely because of the many restrictions imposed by the engineered hydrology, the uncertainties inherent in weather patterns as well as past lawsuits and the potential that every decision could be potentially contested through legal action. To reduce water management-related uncertainties the District is focused on adopting sophisticated predictive tools. In the following section I describe some of these tools, and some of the difficulties encountered in employing these tools.

\section{Models, Data and Decision Making}

To hedge against the uncertainties inherent in climate, water managers use a mix of data-based management strategies. Discussing some of these strategies with District employees and analyzing some of the documents and presentations regarding management practices, I found that the agency prides itself with a strong science-based decision making operating framework. I also found that much of the data used in decision-making practices is model-based. Models are designed to provide guidance where there are limits to reducing risks associated with uncertainty but decisions still need to be made.

\section{Modeling}

The District's main research activities are related to a variety of complex, stateof-the-art modeling exercises. The size of the modeling department today and its involvement in both day-to-day and long-term research projects is telling of the crucial role this department plays here. As one District employee remembers, the modeling 
department grew in 15 years from ten modelers to more than sixty (Interviews; February 2, 2014).

Discussing the ways uncertainty is incorporated in water management practices, District employees referred me to two documents detailing Lake Okeechobee's operation procedures; these focused on describing position analysis and adaptive management as two intertwined management frameworks.

\section{Adaptive Management}

The core principle of adaptive management is learning by doing is. Learning by doing involves experimentation, continuous monitoring, assessment, adjustment, and finally allows for flexibility in modifying the policies that guide management (Gunderson and Light 2006). Adaptive management is the main component addressing uncertainties associated with the large-scale Everglades' restoration project. More precisely, scientists design restoration on a small scale to see how restoration may impact those components for which previous research or experience does not provide an answer. Through adaptive management, scientists can test how the system responds to restoration before implementing. The benefit of such approach is that irrevocable errors can often be avoided. (Interviews; March 11, 2015).

Currently, adaptive management is used in the Decompartimentalization Physical Model Project (the Decomp Model hereafter). The Decomp Model is the second largest adaptive management project in the US after the Grand Canyon experiment. Its construction began on May 2012 and by March 2013 scientists were collecting data. The project addresses some of the uncertainties related to restoring sheet flow in the Everglades, a key component of the pre-drainage ecosystem and the major goal of 
today's proposed restoration activities. Some of the uncertainties that this experiment is testing are related to the ecological effects of levee modifications, the effects of backfilling the canals partially versus completely, and the benefits associated with sheet flow, etc. (Sklar 2013).

The Decomp Model was designed and functions in a typical adaptive management fashion. Scientists today are collecting data to understand all those factors that could be faced once and if this experiment is expanded to the entire Everglades ecosystem. But some of the principles of adaptive management have been expanded to the management of Lake Okeechobee. More precisely, instead of conducting small-scale experiments to assess impacts, managers learn from the past as well as the present. The technical term used to describe this is Passive Assessment (see SFWMD 2007). In other words, the experiment is the entire Okeechobee watershed. Because the managers have been managing this system for decades, they have a decent understanding of what the results of certain actions could be. Therefore, the uncertainties associated with most Lake Okeechobee's operations are smaller than in the case of the Everglades restoration.

Position analysis is a component of this type of management framework. Position analysis is a risk analysis based on the conditions of the Lake at the moment of decision making. In the words of a water manager, "we start with the rainfall forecast"; then we look at "how wet has the land been so far, the saturation"; then "we see the runoff at the end in the system, in the canals and the structures" (Participant Observation Digital Recording; July 24, 2013). Decision makers analyze the risks associated with several decisions by using a probability distribution function. This function tells water managers 
the likelihood of having certain water levels and the likelihoods of having certain results if water is moved in one way versus another

Instead of the 'try this and see what happens approach,' we basically are able to scan the solution space; we go out and we look at a number of different alternatives across the broad spectrum of outcomes and we try to assess how changes in our actions will affect our outcomes (Interview with District employee, June 10 2014).

In other words, numeric models provide different scenarios. The task of the water manager is to pick the scenario with the highest likelihood of providing the desired outcome.

\section{Trade-off Analysis}

Once the position analysis is done, the trade-off evaluation modeling begins. Trade-offs analysis is an important characteristic of the management of Lake Okeechobee as it is an ecosystem that needs to respond to numerous and conflicting requirements. The goal of the trade-off analysis is to maximize the benefits of water releases for environmental purposes while minimizing adverse impacts to Lake Okeechobee's ecology and other water supply users (SFWMD 2010, B-26). For example, one such trade-off analysis looks at the number of months when the Lake's water levels fell below 11 feet (considered below the ecologically beneficial water level of the Lake) and the number of high salinity months in the Caloosahatchee Estuary. The trade-off sensitivity analysis showed water levels that would allow both ecosystems to acquire the least possible stress and which levels would begin to create intolerable damage in either. 
Application of Adaptive Management and Numeric Modeling for Lake Okeechobee. Two things intervene in the practice of decision making in the case of Lake Okeechobee: first of all the Adaptive Protocols document is a guiding document for District employees; therefore, it does not bind District employees to any action; second, the final decision is made by the Army Corps of Engineers. Nevertheless, these protocols are extremely important because they provide the science that guides decision making in situations when the region is not facing a major risk of flooding. In other words, the adaptive management component of Lake Okeechobee operations is activated only in cases when the water in the Lake is not considered critically high. Since 2008, when an Army Corps study revealed that the Lake's levees had structural damages, the critically high level has been set one foot lower than normal. This means that the storage capacity of the lake has been further diminished and has led to additional management pressures. It also means that flood safety issues take priority over all other Lake requirements. The Lake reaches these critically high levels during the wet season, particularly during high intensity rains. I mentioned earlier that the uncertainties associated with Lake Okeechobee water management are not as complex as in the case of Everglades restoration. Nevertheless, the impacts of an unexpected event can be immediate and devastating. For the Army Corps of Engineers, a breech in the levee and flooding is unacceptable, and since the Lake's levee is part of a federal project (the C\&SF), the Corps is the last to call the shots. However, when water is released from the Lake, depending on the quantity, velocity, and nutrient load it carries, it has the potential to destroy entire ecosystems. In addition, if these releases occur at the end of the wet season in expectation of a tropical storm that fails to materialize, agricultural activities in the region will likely suffer due to water 
shortages. While the numeric models, rainfall forecasts, and the other tools at their disposal offer important insights into the possible future scenarios, decision makers face enormous risks with every decision they make. However, they continue to make decisions because there is a clear understanding that, as water managers cited in the first section noted, not taking a decision carries its own risks.

Discussing the management of the Lake with several District employees, I learned that ecologists meet weekly with engineers and hydrologists to assess and analyze the parameters of the Lake and recommend certain releases of water; these decisions also include a focus on ecological concerns as long as there is no major flood risk. If the position analysis shows that the water stages are in the ranges that allow flexibility, the ecological recommendations are likely to be considered.

Mixing numeric modeling exercises, experimental learning, and the incorporation of multiple knowledges help water managers reduce the risks associated with uncertainty. These methods embrace uncertainty and are premised on an understanding that scientists cannot have all the answers when designing an intervention.

\section{Legally-Defensible Science and Decision Making}

Decisions cannot be made unless there is a clear understanding of what the expected outcomes should be. Data becomes a crucial component for action. One of the most often heard complaint among modelers at the District is the disconnect that exists between what models are and how models are perceived. Numerous types of uncertainties are inherent in ecosystem modeling. These depend largely on the type of phenomena being modeled. Two major categories, however, emerged in my discussions: uncertainty inherent in the data (particularly if this is historic data this uncertainty cannot be reduced) 
and uncertainty in the way a model simulates interactions. For example, one engineer explains

I walked once into a meeting where they were comparing two different results for floods through some structures down in Tamiami Trail. The models showed a difference in their annual average flows through the structural flow of like 50 to 100 thousand acre-feet per year. That's a big difference, but the question is, "which model is telling the truth?' Both of them are calibrated; both of them have the goodness of fit right on target. So, how do you say 'okay this model is more reliable than this one?' That's where the sources of uncertainty come! (Interviews; August 19, 2014).

As she further explained, additional analysis would show what the most likely sources of uncertainty are and how these can be quantified to create a picture of what are the ranges within which the modeled system would behave. But decision makers, as the above engineer continued, don't like uncertainties:

When you have to make the decision, you probably want to have something to hang your hat on and say okay: 'I based my decision on this, and I feel confident about it' (Interviews; August 19, 2014).

Three of the six employees with whom I discussed modeling told me that they understand the conundrum decision makers face. Investing large sums of money in projects that 
might not be needed or making a decision that could have negative impacts for one or more of its interest groups while having difficulty proving the long term benefits is not something that decision makers can easily justify. As I was told, models, while using the best available data, are meant to guide the decision making process. The scientists' make them better using their experienced understanding of it. However, the high-stakes of the District's water management decisions means that scientists have to spend a lot of time accumulating data that supports models so that these mimic reality as close as possible.

In other cases data produced by national agencies is preferred to the data produced by District scientists even if this provides higher resolution or accuracy. Discussing the implementation of climate forecasts in the operation of the Lake, one employee told me that at the time they were working on integrating seasonal climate forecasts into the Lake operations the agency was mired in a series of lawsuits. As a result instead of using some of the climate models they had been working on, they preferred to use official climate predictions. I was told that the forecasts coming from official sources, such as the Climate Prediction Center, are designed to have a low risk of being very inaccurate. The way this is achieved is by assuming an average of possible extremes. Thus, whichever way the weather goes, the error will be minimal. In contrast, the agency's researchers focused on creating more accurate predictions rather than averages. However, these predictions run the risk of having a high error if a surprise element interfered. In the words of a District employee

They did not like the hedge part. They always predicted equal chances for being wetter or drier or neutral; they kept saying we were in the middle, that it is not going to be extra 
wet or extra dry. If you predict an extreme, then, if you are

wrong, you are considered way off with your prediction; so

they preferred saying that we are in the middle. But that

was not a way to get the best out of the Lake's schedule!

(Interviews; April 24, 2014).

\section{Conclusions}

In the previous chapter I showed that decision making at the District is shaped by historic legacies that have resulted in numerous legislative limitations. In addition, while groups of interests infuse decision making with more accountability, they have also served to prolong decision-making. In this chapter I continued the discussion of the decision-making context presenting some of the major water management conundrums faced by scientists at the District. I argued that rainfall variation makes decision making extremely difficult. To hedge against some of the risks associated with rainfall variation, decision makers use complex models and experimental learning; they also capitalize on the knowledge and data produced by other expert agencies. Science, along with numerous legal requirements and influential interest groups form some of the key aspects of decision-making at the District. In the following chapter I show that decision-making is shaped by another key element (state politics) and argue that all of these aspects form the context in which climate-change concerns are engaged at the District. 


\section{References}

Aumen, Nicholas G. ; Havens, Karl E. ; Best, G. Ronnie ; Berry, Leonard. n.d. "Predicting Ecological Responses of the Florida Everglades to Possible Future Climate Scenarios: Introduction.(Report)" 55 (4): 741.

“Budget Document Fiscal Year 2007.” 2007. South Florida Water Management District. MaxQda (Financial Reports).

Childers, Daniel L. ; Boyer, Joseph N. ; Davis, Stephen E. ; Madden, Christopher J. ; Rudnick, David T.; Sklar, Fred H. 2006. "Relating Precipitation and Water Management to Nutrient Concentrations in the Oligotrophic 'Upside-down' Estuaries of the Florida Everglades.(Author Abstract).” Limnology and Oceanography 51 (1): 602.

Escobar, Arturo. 2007. "The 'ontological Turn' in Social Theory. A Commentary on 'Human Geography without Scale', by Sallie Marston, John Paul Jones II and Keith Woodward.” Transactions of the Institute of British Geographers 32 (1): 106.

"Final Adaptive Protocols for Lake Okeechobee Operations." 2010a. South Florida Water Management District (in cooperation with U.S Army Corps of Engineers, Jacksonville District and Florida Department of Envirnmental Protection. MaxQDA, Documents.

Goodnough, Abby. 2005. “After Last Year's Hurricanes in Florida, an Unclear Future for 'Lake O'.(National Desk)(Okeechobee Journal).” The New York Times, June 5. Florida International University Library Catalog.

Gunderson, Lance ; Light, Stephen. 2006. "Adaptive Management and Adaptive Governance in the Everglades Ecosystem.” Policy Sciences 39 (4): 323.

Jaynes, Gregory. 1981. "Florida Awaits Rain as Lake Shrinks.” The New York Times, July 24. Florida International University Library Catalog.

Lewis Hornung ; Karl Havens ; Alan Steinman. 2002. "The Managed Recession of Lake Okeechobee, Florida: Integrating Science and Natural Resource Management." Ecology and Society, Vol 6, Iss 2, P 17 (2002). 1708-3087.

New York Times (1923-Current File). 1961. "HOOVER HONORED AT DIKE IN FLORIDA," January 13. 115229064. ProQuest Historical Newspapers: The New York Times (1851-2010).

Nordheimer, Jon. 1986. "Florida Fears That Lake Okeechobee Is Dying." The New York Times, August 23. Florida International University Library Catalog.

. 1987. "Lake's Rescue Threatens Everglades. (Lake Okeechobee, Florida).” The New York Times, July 23. Florida International University Library Catalog. 
Sklar, Fred. 2013. An Update of the Decomp. Physical Model (DPM): The largest AM Assessment in USCOE History. Presentation at the Joint Working Group and Science Coordination Group Meeting (Nov 19, 2013) (retrieved at Everglades restoration Meeting Minutes 2013).

The New York Times. 1965. "WATER IS PUMPED INTO EVERGLADES.” New York Times (1923-Current File), August 3. 116941876. ProQuest Historical Newspapers: The New York Times (1851-2010).

The New York Times. 1981. "Lake Okeechobee Drops Again, Imperiling Florida Water Supply," May 11. Florida International University Library Catalog. 


\section{CLIMATE CHANGE AT THE DISTRICT}

\section{Introduction}

It was July 11, 2013. Standing on an elevated floor that took over the entire front of the room, the thirteen members of the Governing Board formed an imposing presence. The District's Governing Board represents the state's authority in relation to the District; it sets policy and determines policy directions for the entire agency. The Board is composed of nine members appointed by Florida's governor from different areas within the District's administrative boundaries (SFWMD 2013, 9). These appointments are made as vacancies occur, allowing sometimes for a mix of appointees from two different administrations and political parties.

To their right stood a podium where the District employees presented and discussed their views on various agenda items. ${ }^{65}$ The rest of the meeting attendees, myself included, were afforded public seating. Luckily, I found a seat not too far from the Governing Board's front row. Well into the third hour of this meeting, Drew Martin, a volunteer for a local chapter of the Sierra Club, addressed the Board. He asked why the topic of sea level rise had not become part of water supply planning at the District. His major concerns focused on the impact of sea level rise on private property and how potential decreases in property values would further impact the District's tax base. Although the Governing Board members listened to Martin's comments, along with concerns from others, they offered no response. I was intrigued that this particular Governing Board meeting did not address the topics of climate change or sea level rise at all. In fact, out of

${ }^{65}$ Each Governing Board meeting is guided by an agenda that is usually published ahead and available at the entrance in the meeting room. These agendas are also available online at the District's webpage (published after the meeting). 
all eleven Governing Board meetings I attended over the following year, none addressed these topics.

At the 2013 "South Florida Climate-Change Summit," a yearly event organized by the South Florida Climate Compact, a panel consisting of scientists and policy makers argued that the regional approaches to climate-change adaptation needed to be incorporated with existing Everglades restoration efforts. One of the panelists noted however, that the District had lost its authority to take decisions with regards to research activities (Notes, October 16, 2013).

At that time, Miami had developed a reputation as the poster child for climatechange planning following the work of the Task Force. As I noted in Chapter 3, District scientists had been among the first experts invited to be involved in the Task Force activities. The Task Force members identified the District as a key institutional component in the climate-change adaptation process largely due to its expert capabilities as well as its regulatory power in relation to urban development. The District is key to the region's climate-change adaptation also because climate change is expected to affect all major water management aspects, from flood control to water supply and water quality.

The two instances I presented above indicate that by 2013 the District had not incorporated climate change among its concerns. However, as I will show in this chapter, this was not true. While climate change might at times not be visible in the District's official activities, it becomes visible in the practices of some of its scientists and water managers. The shifts between being publicly visible and invisible correspond to shifts in state administration, and some consequential shifts in the membership of the District's Governing Board. 


\section{State Politics and Climate Change}

During the current state administration, led by Governor Rick Scott, references to climate change are virtually absent from the District's documents. In contrast I was able to find many references to climate change in documents created prior to his

administration when Charlie Christ was Florida's governor. It is well-known that climatechange debates have polarized the political spectrum. This polarization influences the practices of this state agency. The lack of climate-change subjects on the Governing Board agenda during the current administration shows how the relation between state politics and the Governing Board influences the District's work.

For example, a simple search on the District's website for the phrase climate change reveals that during the democrat administration there are 24 instances in which climate change is mentioned. Moreover, in 2009, the District published the first and major climate-change report entitled "Interdepartmental Climate Report." The report was authored by a diverse group of experts in various District departments. Of the 24 instances where climate change was part of official agency work, there were five workshops or summits where climate change was the main topic. In addition, climate change was the subject of seven presentations, several District publications, and white papers. Also, during this period, District scientists began attending and providing expert advice within the Miami-Dade County Climate Change Task Force. In contrast, since 2011 the most important publication addressing climate change is titled "Past and Present Trends in Climate and Sea Level for South Florida” (Obeysekera et. al. 2011). Even though the report addresses climate-change concerns, particularly sea level rise impacts, the title seems to deliberately avoid using the term climate change. In addition, I found 
only one brief discussion on climate change in the District's Water Supply Plan for 20112014 (SFWMD 2010). However, my search for the phrase climate change in the District's public documents shows up five times in instances where non-District individuals note the lack of concern with the topic of climate change at the District. Statements like "climate change constitutes a challenge for the region" and "the District should take an active role in planning to meet this challenge" appear in the meeting minutes taken at the Governing Board or Water Resource Advisory Committee meetings.

\section{Other Documents}

The legacies of political shifts in state administrations are visible in the District's budget documents. At the beginning of every fiscal year, the agency formulates a detailed budget justification. The 2009, 2010, and 2011 budget justifications discuss the importance of investing in climate-change and sea-level rise research. The 2011 budget document (published in 2010) identifies this objective as part of the agency's strategic priorities (SFWMD 2011, 4), with allocations within the larger Operations and Maintenance Fund and the Everglades Restoration Fund. These priorities are absent in subsequent years (SFWMD 2012, 2013, 2014). The transition between 2010 and 2012, however, marks a drastic revenue reduction for the agency going from a 1 billion budget in 2010 to a $\$ 578.1$ million budget in 2012 (SFWMD 2012). The budget cuts were largely a consequence of the 2008 financial crisis. However, much of this revenue reduction impacted the Everglades restoration projects, rather than existing water management operations.

The budgetary changes that occurred after the economic depression of 2008 led to unavoidable organizational restructuring. One senior scientist noted the research 
department suffered substantial personnel reductions (going from fifty to eighteen employees in the ensuing years) (Interviews; March 10, 2015). Even though the entire agency was affected by budgetary constraints, the research activities were the first to suffer cutbacks in the restructuring process. Some researchers at the District found these cuts illogical. Scientific and modeling support activities receive $1 \%$ of the total District budget (SFWMD 2012). Therefore, reducing funding in this department fails to substantially improve the agency's budgetary problems. One senior scientist noted

We are constantly being questioned on the importance and need of our research. And we are at a point now that we say: Let's say we get rid of $15 \%$ of the research [about $\$ 4$ million - less than one percent of the District budget], how is that going to help you? (Interviews; March 10, 2015).

According to most of my interviewees, the 2008 financial crisis transformed the District's work environment. Organizational transformation is often anticipated among agency employees during financial crises. Water managers have to distribute funds according to the agency's priorities. Within a water management agency, the routine operations of water distribution and flood control receive a higher degree of importance compared to research activities. This prioritization is evident in the changes that occur within the organizational structure. More precisely, the stand-alone modeling department, which used to engage in both long-term modeling research projects as well as modeling support for the day-to-day operational needs, was integrated in the operations division of the agency. This reorganization occurred while I was conducting my fieldwork. Due to its 
newness, District employees did not know how this change would affect their work, including any work related to climate-change research.

In this first section I showed that at the District climate change becomes a performance that shifts in response to the political orientation of the state administration. According to official documents, meeting minutes, research papers, and budget

allocations, climate change was not a part of the District's work or research objectives during the current administration. However, as the example of the Everglades Technical Meeting showed, this performance seems to be limited only to written documents. Below, I examine in more detail the sites and practices that allow climate change to remain a part of the District's work despite political shifts at the state administrative level.

\section{Enabling Sites, Enabling Practices}

To explain the various mitigation strategies that the District employees use, I find Thomas Gyerin's concept of boundary work useful (Gieryn 1983). Gieryn argues that two centuries ago, Western scientists adopted certain rhetoric to distance themselves from religion and claim an equal place of power in Victorian society. Gieryn defines their performance in rather compromising terms, arguing that scientists used "incomplete, and ambiguous images of science" (Gieryn 1983, 782) to deliberately advance agendas to gain authority and material resources.

Sheila Jasanoff (1990) also used the concept of boundary work in her research on federal advisory bodies. Jasanoff argues that these entities use boundary work as a strategic response to the socio-political challenges these agencies face. For example, Jasanoff (1990) shows that the EPA uses boundary work to build "professional communities, define and exclude non-members, compete for resources, or assert their 
autonomy against external controls" (14). The EPA, Jasanoff argued, employed these strategies to respond to the threatening de-regulation policies adopted during the Ronald Reagan administration. Boundary work, in this case, helped the EPA eliminate any trace of scientific controversy or conflict within its decision-making structures, particularly in relation to its scientific advisory body. The goal was to avoid attracting attention and become a deregulation target.

I argue that at the District, boundary work emerges in similarly politically contentious contexts. Both Gieryn (1983) and Jasanoff (1990) have used the term boundary-work to present scientific practices that entail a level of deceitfulness. My work at the District shows that boundary-work can also be understood as a rather skillful way of transcending the limits imposed by shifting state politics. At the District, boundarywork is particularly visible in the rhetoric of certainty and the focus on proposing "noregrets strategies" (Interviews; February 2, 2014), as well as through practices of networking and capitalizing on external research.

\section{Collaborations and Climate Change Practice Sites}

If climate change is absent from certain official District documents, other sites, such as interagency research collaborations and workshops allow District employees to effectively engage climate-change concerns. For example, District experts attended and organized a series of events that tackled climate-change themes even though "climate change" as a phrase does not appear in the name of the event. During my fieldwork, I witnessed the organization of two major workshops bringing together water managers across the region. The first workshop assessed data availability and needs and discussed related analysis on the effects of sea level rise on earlier processes of salt-water intrusion 
and freshwater availability. The second major workshop addressed questions of planning under vast uncertainties. Other activities included collaborations with Dutch governmental and non-governmental organizations that demonstrated practical expertise in terms of planning for sea-level rise impacts. Additionally, District experts participate in local as well as national events. District experts are officially part of a series of research activities regionally and nationally, and they actively engage universities across the country through collaborative research grants. Notably, they are also a part of the Governing Board of the Southeast Florida Regional Climate Compact (the "Climate Compact" hereafter), the most important regional climate-change planning forum in the region. Expanding the District's research capabilities justifies these collaborations. One scientist noted,

We did not spend a lot of money on climate change research; we've let NOAA do the sea level rise work, and other people measuring $\mathrm{CO}^{2}$, figuring out the difference between carbon dioxide and methane. We did not do that research. (Interviews; March 10, 2015)

These collaborations also serve to channel pressure from the outside to create a more favorable and accepting research space within the District. One employee argued that national recognition of District employees' climate-change research allowed certain openness to this subject and made it less problematic for the District's researchers. As a result, many employees believed climate-change research was slowly receiving a more favorable reception at the upper levels of state and District administration. The openness was also aided by increased media attention to the potential impacts of climate-change in 
the region. At the same time, the emergence of the first regional alliance tackling climatechange adaptation, the Climate Compact, demonstrated the importance of this issue for the District's coastal communities. In this context, a focus on certainty became increasingly efficient within the District's leadership.

\section{Climate Change's Enabling Rhetoric}

Much of the controversy over the validity of climate-change science arises from the wide spectrum of possibilities, really the uncertainties inherent in climate projections. This is especially problematic in South Florida where global climate models have little capacity for capturing local-scale interactions between climate, coastal, and inland hydrology, expanding the risks associated with decision making under great uncertainties. District employees have learned what to say and what not to say about climate change from their interactions with the Governing Board. One employee stated that in the first interaction with the Governing Board, they presented climate-change's potential impacts on the region's hydrology in terms of research results without much consideration to the ways policy might be affected. The Board's reaction, "Go back and give us something we can act on" (District employee paraphrasing the response of the Governing Board; Interviews February 10, 2014), was a learning experience. "We have evolved," this employee noted.

As a result of this learning experience, scientists at the District chose to redefine the scope of climate-change adaptation proposals to address those aspects of climate change that afford more clarity or certainty about its possible impacts. They identified sea level rise as the best strategic choice in terms of tackling one major aspect of the potential impacts of climate change on South Florida's ecology as well as the built environment. 
The official position on why the District should incorporate sea level rise into its work is best described in the 2014 National Academies of Science Review of the Comprehensive Everglades Restoration Project (CERP). The reviewers dedicated an entire chapter of the bi-annual review of the project to climate change and also noted the need to focus on the impacts of sea level rise. The report reads, "In contrast to temperature and precipitation, there is little uncertainty about trends in sea level" (NASR 2014, 109). The same report continues presenting scientific research that shows in no uncertain terms the impacts that sea level rise could have:

Currently, sea level is rising almost an order of magnitude faster than the long-term rate of $0.35 \mathrm{~mm} / \mathrm{yr}$ that prevailed for the past 4,000 years (Scholl and Stuiver, 1967; Scholl et al., 1969; Wanless et al., 1994). Using long-term measurements at Key West, NOAA1 calculated the average sea level rise to be 8.8 inches $(22 \mathrm{~cm})$ over the past century (or $2.2 \mathrm{~mm} / \mathrm{yr}$ ). This value is more than 30 percent higher than the global average of 6.7 inches (17 $\mathrm{cm}$ ) for the 20th century (Figure 5-1) and is consistent with relatively rapid rates observed along the Atlantic and Gulf coasts of North America (IPCC, 2013) (NASR, 2014, 109)

Besides using the discourse of certainty to show the importance and need to tackle some of the impacts of sea level rise, water managers at the District were also able to tap into the District's cautious decision-making culture. As a result, the need to adapt to the 
impacts of sea level rise was presented in terms of insurance policy. During the Everglades Technical Meeting I mentioned above, one water manager noted that climate change must be presented in decision-making contexts in relation to the District's most consequential and, therefore, most important objectives. As I discussed in the previous two chapters, these objectives are flood control and water supply. In water management jargon, scientists refer to these in terms of "levels of service." Levels of service is described in a clause of the CERP which demands the District to provide proof that the implementation of Everglades restoration projects does not interfere adversely with the existing agreements between the District and its water users, both in terms of flood protection and water supply (DEP 2014). ${ }^{66}$ Scientists at the District identified and demonstrated that several flood-control structures were particularly vulnerable to flooding as a result of expected sea level rise impacts.

Focusing on sea level rise proved to be extremely positive in terms of opening a dialogue on climate change at the District; not only that research and planning began focusing on reducing flood vulnerability as a result of sea level rise, but the District allocated some funds towards sea-level rise research. I witnessed this shift at the District's at the beginning of 2014 when the largely volunteer research efforts of a few District employees were remunerated for the first time. More precisely, some of the scientists who had spent time on climate-change/sea-level rise research during their spare hours were able to integrate this work within their other working requirements. This change not only afforded researchers to dedicate more time to climate-change related

\footnotetext{
${ }^{66}$ Section 373.1501(5)(d), F.S: Reasonable Assurances (Final Order Approving the Comprehensive Everglades Restoration Plan, Central Everglades Planning Project.
} 
research, but it also allowed them to branch out and capitalize on the knowledge, skills, and research capabilities the District has to offer. While climate change remained a problematic phrase in written documents, sea level rise emerged free of political undertones and thus an important site for climate-change adaptation research. The success with which District employees transcended the limits imposed on the agency due to the controversial nature of climate-change politics reveals a culture of perseverance and insightfulness on the part of the agency's employees. These characteristics emerge again in the way these employees work on expanding the applied research capabilities in relation to climate change.

Just as in the case of shifting attention from the politically controversial climatechange science and its uncertainties by discussing its certainties, some District employees have come up with yet another powerful discursive tool. District employees found that decision-makers are more open to discussing climate-change adaptation if defined in terms of "no-regret strategies" (Interviews; February 2, 2014). "No-regret strategies" acknowledge that agency leaders are bound by a duty to legitimate their spending and investment in costly infrastructure with "solid science;" since the science of sea level rise still has some degree of uncertainty, "no-regrets strategies" diminish the risks inherent in the scientific uncertainty in two ways: (1) through an emphasis on pre-existing agency objectives and (2) a focus on investments that have no or minimal risk of being needed. As one employee said, it is important to "emphasize water conservation, wastewater reuse, green infrastructure, Everglades restoration” (Interviews; February 2, 2014). While District employees use "no-regret strategies" to advance a climate-change adaptation agenda, "no-regret strategies" also emerge as insurance policies for the agency 
and its employees; "so we feel very comfortable in saying: look we haven't been idle, we've done these things." (Interviews; February 2, 2014).

\section{The Uncomfortable Science and Policy-Making Boundary}

In the first section of this chapter I have shown how the careful handling of climate-change vocabulary has not always been a reality for District employees. Speaking with a former Governing Board member, I learned that during the time she had served on the Governing Board, District employees were given "a safe space" to talk about climatechange impacts and possible solutions (Interviews; May 19, 2014). However, even with that political openness, District employees found that Governing Board members were not able to consider investment in climate-change mitigation or adaptation (Interviews; February 2, 2014). According to District employees, the Board members noted that the large spectrum of possible climate-change impacts makes investment a liability, as it cannot be efficiently justified to Florida's taxpayers. With this reaction in mind, District employees learned that simply presenting research results was inefficient and resulted in setbacks for making climate change an important agency agenda item. District scientists understand the pressures and requirements that policy-makers have to respond to and note that given the large uncertainties inherent in climate models, policy-makers were justified in their decision to ask for more precise data; "they live in a different world!" (Interviews; February 2, 2015), one employee told me, referring to the different political pressures that researchers and policy-makers have. Other employees further explained that the agency's leadership had different political pressures and could not justify expenses that were not strongly backed by data. However, I found that under the current administration even climate-change research has been considered an unjustified expense. 
Boundary work becomes thus a critical tool for District employees. Less subtle than the focus on scientific findings that have a high degree of certainty, or the arguments for "no-regrets strategies", boundary work emerges in the strategic choice of words that researchers use:

We don't call it climate-change, we call it 'climatic trends;' we call it 'landscape elevation change.' We look at how the hydrology of the system can either enhance or degrade the ability of the marshlands to keep up with sea level rise. (Interviews; March 10, 2015).

Referring to something as 'not climate change' is an example of how boundary work creates the illusion of a research practice that does not touch on controversial climatechange topics. This illusion allows certain research flexibility and also allows employees to find a space and place to resolve George Bateson's (1958) famous "double-bind" dilemma $^{67}$ :

And it does not matter what a politician tells you. If the data shows you that we have a sea level rise problem, then as scientists is our obligation to deal with it, and make the politicians comfortable with the wording so that they don't see in it a potential not to be re-elected or whatever.

(Interviews; March 10, 2015).

${ }^{67}$ According to Bateson (1958), the essence of a double bind is two conflicting demands, of which neither can be ignored or escaped. Somebody experiencing a doublebind dilemma feels the pressure of needing to act on something, while being required by a different logic not to act. This results in an unsolvable conflict. 
Much of the boundary work employed becomes, therefore, an important tool for "making politicians comfortable," as the above employee noted. Among these strategies, I distinguished first a focus in communication on the science that has a high degree of certainty; second, an emphasis that the agency's mission remains the same regardless of climate-change impacts with a focus on proposing and choosing "no-regrets strategies" in terms of water management investments. All these strategies enable a continuation of climate-change research despite political changes and many other constraints I have discussed in previous chapters.

\section{Conclusions}

In this chapter I have explored the socio-political life of climate change at the District. I have shown that besides historical legacies, complex and conflictive objectives, and rainfall variability, decision making at the District is also complicated by shifts in state politics. In this difficult decision-making context, some of the District employees manage to pursue climate-change research and adaptation employing boundary-work in insightful and efficient ways. 


\section{References}

“Budget Document Fiscal Year 2007.” 2007. South Florida Water Management District. MaxQda (Financial Reports).

“Budget Document Fiscal Year 2008.” 2008. South Florida Water Management District.

“Budget Document Fiscal Year 2009.” 2009. South Florida Water Management District.

“Budget Document Fiscal Year 2010.” 2010. South Florida Water Management District. Personal MaxQDA (Budgets).

“Budget Document Fiscal Year 2011.” 2011. South Florida Water Management District.

"Budget Document - Tentative Standard Format Submission: Fiscal Year 2014.” 2013. South Florida Water Management District. Personal MaxQDA (Budgets).

“Budget Document Tentative Submission Fiscal Year 2012.” 2011. South Florida Water Management District.

"Central and Southern Florida Project, Water Control Plan for Lake Okeechobee and Everglades Agricultural Area.” 2008. U.S. Army Corps of Engineers, Jacksonville Distrct. Personal MaxQDA (Documents).

“Comprehensive Annual Financial Report.” 2008. South Florida Water Management District. MaxQda (Financial Reports).

. 2009. Financial. South Florida Water Management District. MaxQda (Financial Reports).

—. 2010. South Florida Water Management District. MaxQda (Financial Reports).

—. 2011. South Florida Water Management District. MaxQda (Financial Reports).

- 2012. South Florida Water Management District. MaxQda (Financial Reports).

Gieryn, Thomas F. n.d. "Boundary-Work and the Demarcation of Science from Non-Science: Strains and Interests in Professional Ideologies of Scientists." American Sociological Review 48 (6): 781.

Jasanoff, Sheila. 1990. The Fifth Branch : Science Advisers as Policymakers. Cambridge, Mass: Harvard University Press.

Mikes, Anette. 2011. "From Counting Risk to Making Risk Count: Boundary-Work in Risk Management." Accounting, Organizations and Society 36 (4): 226. 
Obeysekera, J., J. Park, P. Trimble, J. Barnes, J. VanAman, W. Said, and E. Gadzinski. 2011. "Past and Projected Trends in Climate and Sea Level for South Florida." Tehnical Report. Hydrologic and Environmental Systems Modeling. South Florida: South Florida Water Management District.

Obeysekera, Jayantha ; Irizarry, Michelle ; Park, Joseph ; Barnes, Jenifer ; Dessalegne, Tibebe. 2011. "Climate Change and Its Implications for Water Resources Management in South Florida." Stochastic Environmental Research and Risk Assessment 25 (4): 495. 


\section{CONCLUSIONS}

Climate change is a difficult problem for scientists and policy makers alike. In regions like Miami, adaptation to climate change means first of all institutional adaptation. The members of the Task Force spearheaded this process and effectively generated change within the regional bureaucracy. Miami is today the site of a unique and expansive climate-change governance that has unified counties and cities in very visible and significant ways. The process has been arduous and remains difficult. As other anthropologists have noted, one of the most difficult aspects of climate-change adaptation is related to different institutional barriers (Crate and Nuttal 2009). My research on the way climate-change adaptation becomes a part of a region's institutional concerns shows that in 2006, when the Task Force was created, there was no institutional framework for dealing with climate change. This is largely because today's institutional structures are designed to respond to different but interrelated matters in separate ways as Latour (1992) has brilliantly argued. However, as it is evident from the recommendations of the Task Force, climate change will have impacts that span across many agencies and departments. One of the most stymieing events in the history of the Task Force was the moment when its members realized that there was no clear path for implementing climate-change adaptation. Implementing climate-change adaptation needed first and foremost a roadmap that shows the ways key agencies and county departments can incorporate and reshape regional development as well as those key regulatory processes that need to be addressed in the process. The Task Force's main accomplishment was shaped by this confusing process as it revealed that the major task ahead was to capitalize on all the existing collaborations and target with even more purpose county and regional 
departments and agencies with regulatory power. However, my ethnographic research at the District showed that once climate change becomes a concern within such agencies, adaptation and planning encounter a very different set of challenges. More precisely, the District's approach to climate-change concerns is shaped by its numerous legal responsibilities, numerous and competing interests, rigid water infrastructures, financial constrains, and shifting political appointments. In the following pages I use my two research sites, the Task Force and the District, to organize and present a more detailed summary of this dissertation's findings.

\section{Findings: The Task Force}

In the first part of this dissertation I showed that real estate industry is a key component in the regional economy. Past and current urban growth models respond to the needs of this economic sector. Past models of urban growth have allowed sprawl-type development that contributed to the region's water problems. More recently, urban growth patterns encourage densification within already developed areas. While this type of development is more sustainable, it also facilitates potential avenues for gentrification and requires substantial investments in urban infrastructure.

The Task Force has tackled some the complex problems that the potential impacts climate change pose. During the five years of activities, the Task Force members tackled numerous aspects crucial for climate-change adaptation. Most importantly, my analysis on the Task Force minutes and audio recordings shows that adaptation was understood as a process that also has to account for those processes that perpetuate vulnerability to climate change. The urban growth model was highlighted as one such process, particularly in terms of its impacts on the region's water replenishing cycles as well as in 
terms of perpetuating cycles of social vulnerability through the disconnect between housing, the job market, and transportation infrastructure.

Despite important contributions, the Task Force members I interviewed felt that their work had been somewhat in vain because many of the recommendations they produced had not been adopted into law in the three years following the final submission of Task Force recommendations to the Board of County Commissioners. However, in 2014, Miami-Dade County made significant changes to the text of the Comprehensive Development Plan, the county's urban planning regulatory document. Among these the Plan requires all county departments and agencies to include a sea-level rise evaluation component to any new infrastructure investment. However, besides this significant change, my research shows that the Task Force was the engine that led to a significant institutional transformation within the regional bureaucracy. At the end of the Task Force activities, the Southeast Florida Regional Climate Compact integrated and further developed the Task Force recommendation into a regional planning and adaptation project that capitalizes on a series of significant local, regional, and national resources.

\section{Findings: The District}

My analysis of the way climate-change concerns are incorporated in the regional institutional contexts continued with an analysis of the District. The District is atypical among other water management agencies in the US due to its size as well as its multiple and sometimes conflictive responsibilities.

The District's decision-making culture is shaped by a long and contentious water management history. Today, water management is shared among a series of groups of interest. Traditionally two main groups of interest dominated the public domain of 
decision making at the District: agricultural and environmental. Within these groups there is a lot of variation; there are several agricultural businesses and numerous environmental agencies; there are differences in terms of type of agricultural or environmental interests, economic power, and individual level or agency level; some have and continue to exercise more influence than others. The purpose of this dissertation was not to conduct an analysis of the District's interest groups but to describe and understand some of the elements that inform the District's decision-making processes.

The water management history of South Florida as well as the District's court cases show that through legal experiences, or simply by being a part of this agency for decades, some interest groups became experts in water management. From these expert positions, interest groups can and often do challenge the District's decisions. The expansion of decision-making processes that followed the 1990s Restudy process has transformed water management in South Florida. Decision-making processes are more transparent and the agency is more accountable to its users. At the same time, decision making often entails decade-long processes of deliberation, collaboration, and compromise.

These complex social milieus are even more difficult for an agency that has a nearly impossible mission. Despite advanced technologies, in-house climate forecasts, and a state of the art water infrastructure, water management remains highly dependent on seasonal rainfall variations in South Florida. Until current Everglades restoration projects address the water storage issue, water management practices are limited by an inability to store sufficient water during the wet season and access it during the dry 
season. All of these practices are further limited by a series of water management priorities, such as flood control.

In this extremely complex context, climate change, an already vexed political subject, is treated in careful, conservative ways. This is most evident in the way climatechange science is assessed and considered before being brought within the District's policy-making contexts. But the science of climate-change is particularly problematic for resource-management agencies like the District. Florida's peninsular morphology eludes the grid of global modeling. Local models on the potential impacts of climate change are still being developed. It will take years until these will be completed. For decision makers, the inability to accurately model South Florida's climate-change impacts is paralyzing as in the absence of scientific proof they cannot justify the massive investments that climate-change adaptation requires.

In the final chapter of this dissertation, I have explored the ways climate-change concerns are integrated within the District's practices despite its contentious sociopolitical context. Water managers and scientists at the District have found innovative ways to pursue climate-change research. External collaborations and a strategic focus on proposing interventions that do not carry major financial risks show that the District scientists, water managers, and policy-makers have a good understanding of both the agency's decision-making limitations and flexibilities. The decision to channel climatechange adaptation strategies through already well-established, bi-partisan water management objectives, such as flood control and Everglades restoration, proves the robustness and even more importantly the complexity of this agency's intellectual processes. 


\section{Broader Impacts}

This dissertation illustrates that climate change is not merely a scientific and technical endeavor but a cultural one that is largely reflected in the institutional transformations that occur. This research showed that Miami became a global model in terms of climate-change adaptation planning in the process of institutional transformation to plan and meet the challenges of climate change. However, institutional transformation is a long and ongoing process. While the Task Force adaptation framework identified some of the key processes in terms of perpetuating conditions of vulnerability to climate change, adaptation to climate change entails further transformations. More precisely, institutional adaptation needs to reach at the core of its sustaining structures and encourage change at the economic level. While forming coalitions with key departments and agencies within the county and regional agencies is a major step in this process, a further step should involve processes that co-opt effectively the real-estate as well as other key economic sectors of this region. This would insure that some of the discrepancies and difficulties that exist today between state politics and local environmental resource management are replaced by a focus on common goals that integrate sustainable practices and a long-term perspective. Research shows (Whatmore 2009) that important advancements can be established if the public becomes an active and important contributor to decision-making processes. 


\section{LIST OF REFERENCES}

Adger, W.Neil. 2001. "Scales of Governance and Environmental Justice for Adaptation and Mitigation of Climate Change." Journal of International Development 13 (7): 92131 .

Adger, W. Neil, Irene Lorenzoni, and Karen L. O'Brien. 2009. Adapting to Climate Change: Tresholds, Values, Governance. Cambridge; New York: Cambridge University Press.

Adger, W. Neil, J. Paacola, S. Huq, and M. J. Mance. 2006. Fairness in Adaptation to Climate Change. Cambridge, Mass: MIT Press.

Alvarez, Lizette. “Influx of South Americans Drives Miami’s Reinvention.” The New York Times, July 19, 2014. http://www.nytimes.com/2014/07/20/us/20miami.html?_r=0 (accessed March 5, 2015).

Adams Steve, Berry Len, Best Ronnie, Coley Camille, Cox Caroline, Havens Karl, Hefty Nicole, et al. 2012. "Sea Level Rise Summit." Summit presented at the Risk and Response: Sea Level Rise and the Future of Florida and the Coast, Boca Raton, FL, June 21.

Alvarez Carlos, Martinez Joe, Jordan Barbara, Monestime Audrey, Edmonson Audrey, Heyman Sally, Barriero Bruno, et al. 2010. "Green Print." http://www.miamidade.gov/greenprint/pdf/plan.pdf.

American Geophysical Union. 2006. "Hurricanes and the U.S. Gulf Coast: Science and Sustainable Rebuilding." Conference. Reports from AGU: Hurricanes. American Geophisical Union. http://www.agu.org/report/hurricanes/experts.html.

Anderson-Berry, Linda J. 2003. "Community Vulnerability to Tropical Cyclones: Cairns, 1996-2000.” Natural Hazards 30 (2): 209-32.

Anderson, Christopher B, Martinez Pasturi Guillermo, Maria Vanessa Lencinas, Petra K. Wallems, Michelle Moorman, and Amy D. Rosemond. 2008. "Do Introduced North American Beavers Castor Canadensis Engineer Differently in Southern South America? An Overview with Implications for Restoration.” Mammal Society 39: 33-52.

Baker, Earl J. 1995. "Public Response to Hurricane Probability Forecasts." The Professional Geographer 47 (2): 137-47.

Baker, G., and D. Chapman, eds. n.d. Man and Sociaty in Disaster. New York: Basic Books.

Bateman, Julie M., and Bob Edwards. 2002. "Gender and Evacuation: A Closer Look at 
Why Women Are More Likely to Evacuate for Hurricanes." Natural Hazards Review 3 (3): 107-17.

Benzie, Magnus, Alex Harvey, and Karen Miller. 2011. "Adaptation in UK Cities: Heading in the Right Direction?" In Resilient Cities: Cities a Nd Adaptation to Climate Change Proceedings of the Global Forum 2010, edited by Konrad OttoZimmermann and Monika Zimmermann, 1st ed., 231-41.

Blaikie, Piers, Terry Cannon, Ian Davis, and Ben Wisner. 1994. At Risk: Natural Hazards, People's Vulnerability and Disasters. Routledge.

Blake, Eric S., Edward N. Rappaport, and Cristopher W. Landsea. 2007. "The Deadliest, Costliest, And Most Intense United States Tropical Cyclones From 1851 To 2006 (And Other Frequently Requested Hurricane Facts)." NOAA Technical Memorandum NWS TPC-5. http://www.nhc.noaa.gov/pdf/NWS-TPC-5.pdf.

Bollig, Michael. n.d. Risk Management in a Hazardous Environment: A Comparative Study of Two Pastoral Societies.

Borrero, Luis Alberto, and Nora Viviana Franco. n.d. "Early Patagonian HunterGatherers:Subsistence and Technology." Journal of Anthropological Research.

Bouwer, L.M., and P. Vellinga. 2007. "On the Flood Risk in the Netherlands." In Flood Risk Management in Europe, 25:469-84. Advances in Natural and Technological Hazards Research. Springer Netherlands. http://dx.doi.org/10.1007/978-1-4020-4200324.

Bradshaw, G.A., and Jeffrey G. Borchers. 2000. "Uncertainty as Information: Narrowing the Science-Policy Gap." Ecology and Society 4 (1).

http://www.consecol.org/vol4/iss1/art7/.

Braun, Bruce. 2002. The Intemperate Rainforest: Nature, Culture, and Power on Canada's West Coast. Minneapolis: University of Minnesota Press.

- 2013. "The Resilience Dispositif: Governing Urban Life in an Age of Climate Change." Lecture presented at the Colloquium Series, Florida International University, February 28.

Christiansen, Jonathan. 2009. Four Stages of Social Movements. EBSCO Research Starters. At http://www.ebscohost.com/uploads/imported/thisTopic-dbTopic-1248.pdf

Cox, Wendell "The Housing Crash and Smart Growth" National Center for Policy Analysis, Policy Report No. 335, June 2011. http://www.ncpa.org/pdfs/st335.pdf (accessed March 5, 2015).

Bulkeley, Harriet, and Peter Newell. 2009. Governing Climate Change. Taylor and 
Francis.

Bush, David M., William J. Neal, Norma J. Longo, Kenyton C. Lindeman, Deborah F Pilkey, Luciana Slomp Esteves, John D. Congeleton, and Orrin H. Pilkey. 2004. Living with Florida's Atlantic Beaches: Coastal Hazards from Amelia Island to Key West. Living with the Shore. Duke University Press.

Castree, Noel, and Bruce Braun, eds. 2001. Social Nature: Theory, Practice and Politics. Malden, Mass: Blackwell Publishers.

Chouinard, Omer, Steve Plante, and Giles Martin. 2008. "The Community Engagement Process: A Governance Approach in Adaptation to Coastal Erosion and Flooding in Atlantic Canada (PART I: The Essential Presence of the Actor." Canadian Journal of Regional Science 31 (3): 507-24.

Colle, Brian A, Katherine Rojowsky, and Frank Buonaito. 2010. "New York City Storm Surges: Climatology and an Analysis of the Wind and Cyclone Evolution." Journal of Applied Meteorology and Climatology 49 (1): 85-100.

Comfort, L., Ben Wisner, Susan L. Cutter, R Pulwarty, Kenneth Hewitt, Anthony OliverSmith, J. Wiener, M Fordham, Walter Gillis Peacock, and F Krimgold. 1999. "Reframing Disaster Policy: The Global Evolution of Vulnerable Communities." Environmental Hazards 1: 39-44.

Corbett, Julia B., and Jessica L. Durfee. 2004. "Testing Public (Un)Certainty of Science." Science Communication 26 (2): 129-51. doi:10.1177/1075547004270234.

Crate A. Susan. 2011. "Climate and Culture: Anthropology in the Era of Contemporary Climate Change." Annual Review of Anthropology 40: 175-94.

Crate, Susan A., and Mark Nuttall, eds. 2010. The Anthropology of Climate Change: From Encounters to Actions. Left Coast Press, INC.

Cutter, Susan L. 2010. "Vulnerability to Environmental Hazards." Prograss in Human Geography 20 (4): 529-39.

Daniel B. Metcalfe. 20140521////. "Climate Science: A Sink down under." Nature 509 (7502): 566.

—. 20140521////. “Climate Science: A Sink down under.” Nature 509 (7502). http://dx.doi.org/10.1038/nature13341.

DeLanda, Manuel. 2006. A New Philosophy of Society: Assembalhe Theory and Social Complexity. London: Continuum. 
Della Porta, Donatella, and Mario Diani. 2006. Social Movements: An Introduction $\left(2^{\text {nd }}\right.$ ed.). Malden, MA: Blackwell.

Demeritt, David. 2001. "The Construction of Global Warming and the Politics of Science." Annals of the Association of American Geographers 91 (2): 307-37.

Diemberger, Hildegard, Kirsten Hastrup, Simon Schaffer, Charles F. Kennel, David Sneath, Michael Bravo, Hans-F. Graf, et al. 2012. "Communicating Climate Knowledge: Proxies, Processes, Politics.” Current Anthropology 53 (2): 226-44. doi:10.1086/665033.

Doornkamp, J. C. 1998. "Coastal Flooding, Global Warming and Environmental Management." Journal of Environmental Management 52 (4): 327-33.

doi:10.1006/jema.1998.0188.

Douglas, Mary. 1984. Risk Acceptability according to the Social Sciences. New York: Russell Sage.

Douglas, Mary, and Aaron Wildavsky. n.d. Risk and Culture: An Essay on the Selection of Technological and Environmental Dangers. Berkley: University of California Press.

Escobar, Arturo. 2007. "The 'ontological Turn' in Social Theory. A Commentary on 'Human Geography without Scale', by Sallie Marston, John Paul Jones II and Keith Woodward." Transactions of the Institute of British Geographers 32 (1): 106-11. doi:10.1111/j.1475-5661.2007.00243.x.

Ethn, Dis, William W Darrow, Julie E Montanea, Paula B Fernandez, Ula F Zucker, Dionne P Stephens, and Hugh Gladwin. 2004. "Eliminating Disparities in HIV Disease: Community Mobilization to Prevent HIV Transmission among Black and Hispanic Young Adults in Broward County, Florida." Ethnicity \& Disease 14 (3 Suppl 1).

Ferguson, James. 1990. The Anti-Politics Machine: “Development," Depoliticization, and Bureaucratic Power in Lesotho. Cambridge: Cambridge University Press.

Few, Roger; Brown, Katrina ; Tompkins, Emmal. n.d. "Public Participation and Climate Change Adaptation: Avoiding the Illusion of Inclusion." Climate Policy 7 (1): 46.

Fischhoff, Baruch. 1990. "Understanding Long Term Environmental Risks." Risk and Uncertainty 315.

Fiske, Shirley J. 2009. "Global Change Policymaking from Inside the Beltway: Engaging Anthropology." In The Anthropology of Climate Change: From Encounters to Actions, edited by Susan A. Crate and Mark Nuttall. Walnut Creek, CA: Left Coast Press, INC.

Fortun, Kim. 2001. Advocacy after Bhopal: Environmentalism, Disaster, New Global Orders. University of Chicago Press. 
- 2004. "Environmental Information Systems as Appropriate Technology." Design Issues 20 (3): 54-65.

Gandy, Mathew. 1996. "Crumbling Land: The Postmodernity Debate and the Analysis of Environmental Problems.” Progress in Human Geography 20 (1): 23-40.

Grinsted Aslak, Moore John C., and Jevrejeva Svetlana. 2013. "Projected Atlantic Hurricane Surge from Rising Temperatures." Proceedings of the National Academy of Sciences of the United States of America. 110 (14): 5369-73.

Grundwald, Michael. 2007. The Swamp - The Everglades, Florida, and the Politics of Paradise. Simon and Schuster Paperbacks.

Gerrity, Michael. “After Historic 2008 Crash, Downtown Miami Among Nation's Most Active Residential Markets in 2012.” The World Property Journal, March 13, 2012. http://www.worldpropertyjournal.com/north-america-residential-news/miami-topresidential-real estate-markets-residential-closings-occupancy-study-lewis-goodkingoodkin-consulting-focus-real estate-advisors-focus-real estate-advisors-miami-ddamiami-downtown-5405.php (accessed March 5, 2015).

Heazle, Michael ; Tangney, Peter ; Burton, Paul ; Howes, Michael ; Grant - Smith, Deanna; Reis, Kim ; Bosomworth, Karyn. 2013. "Mainstreaming Climate Change Adaptation: An Incremental Approach to Disaster Risk Management in Australia." Environmental Science and Policy 33 (November): 162.

Heaps, N. S. 1983. "Storm Surges, 1967-1982." Geophysical Journal of the Royal Astronomical Society 74 (1): 331-76. doi:10.1111/j.1365-246X.1983.tb01883.x.

Helmer, M, and Mark Nuttall. 2006. "Natural Disasters and Climate Change.” Disasters 30: $1-4$.

Helmreich, Stefan. 2009. Alien Ocean: Anthropological Voyages in Microbial Seas. Berkeley and Los Angeles, California: University of California Press.

Hewitt, Kenneth. 1983. Interpretations of Calamity from the View Point of Human Ecology. Allen and Unwin.

Heynen, Nik, Maria Kaika, and Erik Swyngedouw, eds. 2006. In the Nature of Cities: Urban Political Ecology and the Politics of Urban Metabolism. New York: Routledge.

Hoffman, Suzannah, and Anthony Oliver-Smith. 2002. Catastrophe and Culture: The Anthropology of Disaster. Santa Fe: School of AMerican Research Press.

Hofstede, J.L.A. 2007. "Comrisk - A Transnational Project of Public Authorities on Coastal Risk Management." In Flood Risk Management in Europe, 25:77-88. Advances 
in Natural and Technological Hazards Research. Springer Netherlands.

http://dx.doi.org/10.1007/978-1-4020-4200-3_5.

Houck, Oliver A. 2010. Taking Back Eden: Eight Environmental Cases That Changed the World. Washingtong, DC: Island Press.

Houston, Samuel H, Wilson A Shaffer, Mark D Powell, and Jye Chen. 1999.

"Comparisons of HRD and SLOSH Surface Wind Fields in Hurricanes: Implications for Storm Surge Modeling." Weather and Forecasting 14 (5): 671-86.

Hubbert, Graeme D, Greg J Holland, Lance M Leslie, and Michael J Manton. 1991. “A Real-Time System for Forecasting Tropical Cyclone Storm Surges." Weather and Forecasting 6 (1): 86-97. doi:10.1175/1520-0434(1991)006<0086:ARTSFF>2.0.CO;2.

Huber, U.M., Vera Markgraf, and F Schabitz. 2004. "Geographical and Temporal Trends in Late Quaternary Fire Histories of Fuego-Patagonia, South America." Quartenary Science Review 23 (9-10): 1079-97.

Humes, E. 2010. Eco-Barons: The New Heroes of Environmental Activism. New York: ECCO.

Igoe, Jim ; Brockington. 20071001. "Neoliberal Conservation: A Brief Introduction." Conservation and Society 5 (4).

http://www.conservationandsociety.org/article.asp?issn=0972-

4923; year $=2007 ;$ volume $=5 ;$ issue $=4 ;$ spage $=432 ;$ epage $=449 ;$ aulast $=$ Igoe;type $=0$.

Ikeme, Jekwu. 2003. "Equity, Environmental Justice and Sustainability: Incomplete Approaches in Climate Change Politics." Global Environmental Change 13 (3): 195-206. doi:10.1016/S0959-3780(03)00047-5.

Irish, Jennifer L, Donald T Resio, and Jay J Ratcliff. 2008. "The Influence of Storm Size on Hurricane Surge." Journal of Physical Oceanography 38 (9): 2003-13.

Jain, Indu, P. Chittibabu, Neetu Agnihotri, S. Dube, P. Sinha, and A. Rao. 2006. "Simulation of Storm Surges Along Myanmar Coast Using a Location Specific Numerical Model." Natural Hazards 39 (1): 71-82.

- 2007. "Numerical Storm Surge Model for India and Pakistan." Natural Hazards 42 (1): $67-73$.

Jasanoff, Sheilla. 1993. "Relating Risk Assessment and Risk Management." EPA L. 19 (35).

_ 2010. "Testing Times for Climate Change." Science, 191-205.

Jelesnianski, Chester P. 1966. "Numerical Computations Of Storm Surges Without 
Bottom Stress." Monthly Weather Review 94 (6): 379-94.

Kantha, L. 2006. “Time to Replace the Saffir-Simpson Hurricane Scale?” EOS, Transactions, American Geophysical Union 87 (1): 3-6. doi:10.1029/2006EO010003.

Kusenbach, Margarethe, Jason Simms, and Graham Tobin. 2010. "Disaster Vulnerability and Evacuation Readiness: Coastal Mobile Home Residents in Florida." Natural Hazards 52 (1): 79-95.

Lachlan, Kenneth A., Jennifer Burke, Patric R. Spence, and Donyale Griffin. 2009. "Risk Perceptions, Race, and Hurricane Katrina." Howard Journal of Communications 20 (3): 295-309.

Latour, Bruno. 1993. We Have Never Been Modern. Translation by Harvester Wheatsheaf and the President and Fellows of Harvard College.

- 2004. The Politics of Nature: How to Bring Sciences into Democracy. President and Fellows of Harvard College.

Lorenzoni, Irene, and Mike Hulme. 2009. "Believing Is Seeing: Laypeople's Views of Future Socio-Economic and Climate Change in England and in Italy." Public

Understanding of Science 18 (4): 383-400. doi:10.1177/0963662508089540.

Lorenzoni, Irene, Sophie Nicholson-Cole, and Lorraine Whitmarsh. "Barriers Perceived to Engaging with Climate Change among the UK Public and Their Policy Implications." Global Environmental Change 17 (3-4): 445-59. doi:10.1016/j.gloenvcha.2007.01.004.

Lowe, E. J. 2006. The Four-Category Ontology: A Metaphisical Foundation for Natural Science. Oxford: Clarendon Press.

Magee, Paul. n.d. From Here to Tierra Del Fuego. Urbana.

Mahron, Charles, Joe Minicozzi, Douglas Yoder, and Manny Diaz. 2013. "Miami's Next Big Issue: Water and Sewer Fixes and Ways to Pay." presented at the Urban Land Institute, ULI, Hampton Inn and Suites Miami, March 20.

Maldonado, V, and R Faundez. 2005. "Asesoria Para La Actualizacion Base de Datos Cartografica de Areas Silvestres Protegidas a Nivel Nacional." Informe Final. Programa de Biodivesidad CODEFF/CONAMA.

Manning, Robert E. 2003. "Social Climate Change: A Sociology of Environmental Philosophy." In Reconstructing Conservation: Finding Common Ground, 207-22. Washington DC: ISland Press.

Mansur, Maria, and Raquel Pique. 2009. "Between the Forest and the Sea: Hunter- 
Gatherer Occupations in the Subanthartic Forests in Tierra Del Fuego, Argentina." Artic Anthropology 46 (1-2): 144-57.

Mingle Johnatan. 2013. "Social Movements and Climate Change." Center for the Environment Newsletter 5 (1).

Meyer, Robert. "How Climate Change is Fueling the Miami Real Estate Boom." Bloomberg Business, October 20, 2014. http://www.bloomberg.com/bw/articles/2014-1020/how-climate-change-is-fueling-the-miami-real estate-boom\#p2 (accessed February 15, 2015).

Morgan, Curtis. 2013. "Deep Trouble: How Sea-Rise Could Cause Havoc in South Florida." The Miami Herald, March 17. http://www.miamiherald.com/2013/03/17/vfullstory/3291204/deep-trouble-how-sea-rise-could.html\#storylink=cpy.

Morss, Rebecca E, and Mary H Hayden. 2010. "Storm Surge and 'Certain Death': Interviews with Texas Coastal Residents Following Hurricane Ike." Weather, Climate, and Society 2 (3): 174-89.

Nelson, Michael, and Guillermo Geisse. 2001. "Las Leccciones Del Caso Tompkins Para Politica Ambiental Y La Inversion Extranjera En Chile.” Ambiente Y Desarrllo XVII (3): $14-26$.

Nicholls Robert J., Jason A. Lowe, David A. Vaughan, Tim Lenton, Andrey Ganopolski, Richard S. J Tol, and Athanasios Vafeidis. 2006. "Metrics for Assessing the Economic Benefits of Climate Change Policies" Organization for Economic Co-operation and Development - Environment Directorate; Environment Policy Committee - Working Party on Global and Structural policies.

http://www.oecd.org/officialdocuments/displaydocumentpdf?cote=env/epoc/gsp $\% 282006$ $\% 293 /$ final\&doclanguage $=$ en .

Nienhuis, Piet H. 2008. "Floods and Flood Protection." In Environmental History of the Rhine-Meuse Delta, 231-68. Springer Netherlands. http://dx.doi.org/10.1007/978-14020-8213-9_9.

Nijman, Jan. 2007. “Introduction - Comparative Urbanism.” Urban Geography 28 (1): 16.

Niklas, Luhmannn. 1993. Risk: A Sociological Theory. Berlin: Walter de Gruyter. O’Brien, Geoff, Phil O'Keefe, Joanne Rose, and Ben Wisner. 2006. "Climate Change and Disaster Management." Disasters 30 (1): 64-80.

Ogden, Laura. 2008. "The Everglades Ecosystem and the Politics of Nature." American Anthropologist 110 (1): 21-32. doi:10.1111/j.1548-1433.2008.00005.x.

Oliver-Smith, Anthony. 1986. Natural Disasters and Cultural Responses. VA: College of 
William and Mary.

—. 1996. "Anthropological Research on Hazards and Disasters." Annual Review of Anthropology 25: 303-28.

Oliver-Smith, Anthony, and Susannah Hoffman. 1999. The Angry Earth: Disaster in Anthropological Perspective. New York: Routledge.

Oreskes, Naomi. The Scientific Consensus on Global Warming. Science 3 December 2004: Vol. 306. no. 5702, p. 1686

Paine, Robert. 1992. "Chernobyl Reaches Norway: The Accident, Science and the Threat of Cultural Knowlege.” Public Understanding of Science 1 (3): 61-280.

Palmer, Tim. 20140523////. “Atmospheric Science. Record-Breaking Winters and Global Climate Change.” Science (New York, N.Y.) 344 (6186): 803.

_ 20140523////. "Atmospheric Science. Record-Breaking Winters and Global Climate Change.” Science (New York, N.Y.) 344 (6186). http://pubmed.gov/24855240.

Panigrahi, J., J. Tripathy, and A. Murty. 2010. "Extremity Analysis of Storm Surge for Fixing Safe Design Water Level." Natural Hazards, August, 1-12.

Peacock, Walter G, Hugh Gladwin, and Betty H Morrow. 1997. Hurricane Andrew: Ethnicity, Gender and the Sociology of Disaster. Routledge.

Peacock, Walter Gillis. 2003. "Hurricane Mitigation Status and Factors Influencing Mitigation Status among Florida's Single-Family Homeowners." Natural Hazards Review 4 (3): 149-58.

Peterson, Nicole, and Kenny Broad. 2009. "Climate and Weather Discourse in Anthropology: From Determinism to Uncertain Futures." In The Anthropology of Climate Change: From Encounters to Actions, edited by Susan A. Crate and Mark Nuttall. Walnut Creek, CA: Left Coast Press, INC.

Pielke, Roger A. 2007. The Honest Broker: Making Sense of Science in Policy and Politics. Cambrige University Press.

Pielke, Roger, Gwyn Prins, Steve Rayner, and Daniel Sarewitz. 2007. "Climate Change 2007: Lifting the Taboo on Adaptation." Nature 445 (7128): 597-98. doi:10.1038/445597a.

Pliscoff, P, and T Fuentes-Castillo. 2011. "Representativeness of Terrestrial Ecosystems in Chile's Protected Area System.” Environmental Conservation 38: 303-11. 
Plunz, Richard, and Maria Paola Sutto, eds. 2008. Urban Climate Change at Crossroads. Surrey, England: Ashgate Publishing Limited.

Pristin, Terry. "Miami’s Condo Market Rebounds, Stoking Building Boom.” The New York Times, April 30, 2013. http://www.nytimes.com/2013/05/01/realestate/commercial/miamis-condo-marketrebounds-stoking-a-fresh-building-boom.html (accessed March 5, 2015)

Pollock, Philip H. III. 1994. 'Issues, Values, and Critical Moments: Did 'Magic' Johnson Transform Public Opinion on AIDS?.” American Journal of Political Science 38 (2).

Powell, Mark D, and Timothy A Reinhold. 2007. "Tropical Cyclone Destructive Potential by Integrated Kinetic Energy." Bulletin of the American Meteorological Society 88 (4): 513-26.

Powers, William. 2005. "Storm surge.(Hurricane Katrina).” National Journal. Poyar, Kyle Andrew, and Nancy Beller-Simms. 2010. "Early Responses to Climate Change: An Analysis of Seven U.S. State and Local Climate Adaptation Planning Initiatives." Weather, Climate, and Society 2 (3): 237-48.

Puntenney P. J. 2009. "Where Managerial and Science Knowlege Meet Sociocultural Systems: Local Realities, Global Responsabilities." In The Anthropology of Climate Change: From Encounters to Actions, edited by Susan A. Crate and Mark Nuttall. Walnut Creek, CA: Left Coast Press, INC.

Qureshi, Salman, Syed Jamil Hasan Kazmi, and Jorgen H. Breuste. 2010. "Ecological Disturbances due to High Cutback in the Green Infrastructure of Karachi: Analyses of Public Perception about Associated Health Problems." Urban Forestry \& Urban Greening 9 (3): 187-98. doi:10.1016/j.ufug.2009.08.003.

Rabassa, Jorge, Andrea Coronato, Gustavo Bujalesky, Mónica Salemme, Claudio Roig, Andrés Meglioli, Calvin Heusser, et al. 2000. "Quaternary of Tierra Del Fuego, Southernmost South America: An Updated Review." Nat Rutter Honorarium 68-71 (0): 217-40. doi:10.1016/S1040-6182(00)00046-X.

Raffles, H. 2011. "Mother Nature's Melting Pot.” The New York Times, 2 edition. Rappaport, Roy. 1988. "Toward Postmodern Risk Analysis.” Risk Analysis 8 (2).

Reisigl Martin. 2008. “Analyzing Political Rethoric.” In Qualitative Discourse Analysis in the Social Sciences, edited by Ruth Wodak and Michal Krzyzanowski. Palgrave Macmillan.

Resio, Donald T, and Joannes J. Westerink. 2008a. "Modeling the Physics of Storm Surges." Physics Today 61 (9): 33-38. 
Resio, Donald T., and Joannes J. Westerink. 2008b. "Modeling the Physics of Storm Surges." Physics Today.

Revi, A., and A. Singh. 2007. "Cyclone and Storm Surge, Pedestrian Evacuation and Emergency Response in India." In Pedestrian and Evacuation Dynamics 2005, 119-30. Springer Berlin Heidelberg. http://dx.doi.org/10.1007/978-3-540-47064-9_11.

Riad, Jasmin K., Fran H. Norris, and Barry R. Ruback. 1999. "Predicting Evacuation in Two Major Disasters: Risk Perception, Social Influence, and Access to Resources1." Journal Of Applied Social Psichology 29 (5): 918-34.

Robbins, Paul, and Sarah A. Moore. 2013. "Ecological Anxiety Disorder: Diagnosing the Politics of the Anthropocene." Cultural Geographies 20 (1): 3-19. doi:10.1177/1474474012469887.

Robinson, Lin, Joshua P. Newell, and John M. Marzluff. 2005. "Twenty-Five Years of Sprawl in the Seattle Region: Growth Management Responses and Implications for Conservation." Landscape and Urban Planning 71 (1): 51-72.

Saavedra, Casilda, and William W. Budd. 2009. "Climate Change and Environmental Planning: Working to Build Community Resilience and Adaptive Capacity in Washington State, USA.” Habitat International 33 (3): 246-52.

Sallie Marston, John Paul Jones III, and Keith Woodward. 2005. "Human Geography Without Scale." Trans Inst Br Geogr NS 30: 416-32.

Shackley, Simon, and Brian Wynne. 1996. "Representing Uncertainty in Global Climate Change Science and Policy: Boundary-Ordering Devices and Authority." Science, Technology \& Human Values 21 (3): 275-302. doi:10.1177/016224399602100302.

Sharma, Upasna, Anand Patwardhan, and D. Parthasarathy. 2009. "Assessing Adaptive Capacity to Tropical Cyclones in the East Coast of India: A Pilot Study of Public Response to Cyclone Warning Information." Climatic Change 94 (1): 189-209. Sheila, Jasanoff. 1990. The Fifth Branch: Science Advisors as Policymakers. Harvard University Press.

Sharma, Divya, and Sanjay Tomar. 2010. "Mainstreaming Climate Change Adaptation in Indian Cities." Environment and Urbanization 22 (2): 451.

Stults, Missy. 2010. "Miami-Dade County Selected as U.S. Representatiove at 2010 Resilieny Cities Conference." Sustainable Cities and Counties.

Suter, Larry, Thomas Birkland, and Raima Larter. 2009. "Disaster Research and Social Network Analysis: Examples of the Scientific Understanding of Human Dynamics at the National Science Foundation." Population Research and Policy Review 28 (1): 1-10. 
Sklar, Fred. 2013. An Update of the Decomp. Physical Model (DPM): The largest AM Assessment in USCOE History. Presentation at the Joint Working Group and Science Coordination Group Meeting (Nov 19, 2013) (retrieved at Everglades restoration Meeting Minutes 2013).

Vayda, Andrew, and Bonnie J. McCay. 1975. "New Directions in Ecology and Anthropology." Annual Review of Anthropology 1975: 293-306.

Weaver Catherine. 2008. Hypocrisy Trap: The World Bank and the Poverty Reform. Princeton University Press.

Whatmore, Sarah. 2002. Hybrid Geographies: Natures, Cultures, Spaces. London: SAGE Publications.

Whitehead, John C., Bob Edwards, Marieke Van Willigen, John R. Maiolo, Kenneth

Wilson, and Kevin T. Smith. 2000. "Heading for Higher Ground: Factors Affecting Real and Hypothetical Hurricane Evacuation Behavior." Global Environmental Change Part B: Environmental Hazards 2 (4): 133-42. doi:10.1016/S1464-2867(01)00013-4.

Winchester, Peter. 1992. Power, Choice and Vulnerability. London: James and James Publications.

Zehr, Stephen C. 2000. "Public Representations of Scientific Uncertainty about Global Climate Change." Public Understanding of Science 9 (2): 85-103. doi:10.1088/0963$6625 / 9 / 2 / 301$.

Zia, Asim, and Anne Marie Todd. 2010. "Evaluating the Effects of Ideology on Public Understanding of Climate Change Science: How to Improve Communication across Ideological Divides?" Public Understanding of Science 19 (6): 743-61. 


\section{APPENDICES}

\section{State and regional Conferences and Workshops Attended}

National Environmental Journalists conference, Miami, October 19-23, 2011

CLEO Anniversary Celebrarion, Pinecrest, FL, December 1, 2012

University of Miami, Climate Communicators Workshop Training, Spring 2011

Florida Atlantic University, Sea Level Rise Conference, june 21, 2012

Urban Land Institute, “can Southeast Florida Stay Afloat Despite the Changing Climate?

How Sea Level Rise is Already Altering our Built Environment” Miami, FL, January 8 2013

National Climate Assessment, Regional Townhall Meeting, Tampa, FL February 19, 2013

South Florida Climate Action Partners Workshop, Boca Raton FL, March 2, 2013

Florida Sea Grant Adaptive Planning Workshop, Davie, FL April 19, 2013

Climate Change Planning Workshop, Department of Environmental Protection, Overtown Transit Village, Miami, October 3, 2013

Seven50 Opening Summit, Delray Beach, FL June 27, 2012

Marshal Foundation Climate Change Summit, 2013, 2014

Sea level Rise Summit 2012, 2013, 2014

Florida Atlantic University, CES - Everglades Workshop

Sea Level Rise Task Force, Miami Courthouse, May 2014

\section{Participant Observation at the District}

WRAC meeting June $5^{\text {th }} 2014$

WRAC May 62013 
WRAC August 82013

Governing Board Meeting June 122014

Governing Board Meeting, July 11, 2013

Salt Water Intrusion Workshop, July 232014

Robust Decision Making Workshop, September 5, 2014

\section{Task Force Ethnographic Material}

Miami Dade County Climate Change Advisory Task Force Meeting Minutes

Miami Dade County, Final Official Minutes, Climate Change Advisory Task Force

(CCATF) February 23, 2007

Miami Dade County, Final Official Minutes, Climate Change Advisory Task Force

(CCATF) March 15, 2007

Miami Dade County, Final Official Minutes, Climate Change Advisory Task Force

(CCATF) April 19, 2007

Miami Dade County, Final Official Minutes, Climate Change Advisory Task Force (CCATF) January 11, 2008

Miami Dade County, Final Official Minutes, Climate Change Advisory Task Force (CCATF) , January 14, 2008

Miami Dade County, Final Official Minutes, Climate Change Advisory Task Force (CCATF), March 202008

Miami Dade County, Final Official Minutes, Climate Change Advisory Task Force (CCATF), May 2, 2008

Miami Dade County, Final Official Minutes, Climate Change Advisory Task Force (CCATF), February 20, 209

Miami Dade County, Final Official Minutes, Climate Change Advisory Task Force (CCATF) April 302009 
Miami Dade County, Final Official Minutes, Climate Change Advisory Task Force (CCATF), November 132009

Miami Dade County, Final Official Minutes, Climate Change Advisory Task Force (CCATF) , January 22, 2010

Miami Dade County, Final Official Minutes, Climate Change Advisory Task Force (CCATF), April 262010

Miami Dade County, Final Official Minutes, Climate Change Advisory Task Force (CCATF), December 13, 2010

\section{Steering Committee Meetings}

Miami Dade County, Final Official Minutes, Climate Change Advisory Task Force (CCATF), Steering Committee, February 8, 2008

Meeting Audio Recording; February 22008

Miami Dade County, Final Official Minutes, Climate Change Advisory Task Force (CCATF), Steering Committee, May 22008

Audio Recording, May 22008

Miami Dade County, Final Official Minutes, Climate Change Advisory Task Force (CCATF), Steering Committee, November 142008

Audio recording, November 142008

Miami Dade County, Final Official Minutes, Climate Change Advisory Task Force (CCATF), Steering Committee, June 24, 2009

Meeting Audio Recording, June 24, 2009

Miami Dade County, Final Official Minutes, Climate Change Advisory Task Force (CCATF), Steering Committee, November 132009

Audio Recording, November 13, 2009

\section{Documents}

"Central and Southern Florida Project, Water Control Plan for Lake Okeechobee and Everglades Agricultural Area.” 2008. U.S. Army Corps of Engineers, Jacksonville 
Distrct. Personal MaxQDA (Documents).

"Final Adaptive Protocols for Lake Okeechobee Operations." 2010. South Florida Water Management District (in cooperation with U.S Army Corps of Engineers, Jacksonville District and Florida Department of Envirnmental Protection. Personal MaxQDA (Documents).

"Governing Board Monthly Meeting Minutes." 2014a. South Florida Water Management District. Personal MaxQDA (Documents).

(Documents).

“Governing Board Montly Meeting Minutes.” 2014. South Florida Water Management District. Personal MaxQDA (Documents).

Korten, Tristan. 2015. "In Florida, Officials Ban Term Climate Change." Center for Investigative Reporting. Personal MaxQDA (Newspaper Articles). Accessed April 30.

"Meeting Minutes, Water Resources Advisory Commissio (WRAC) Adaptive Protocols for Lake Okeechobee Regulation Schedule 2008, Issues Workshop.” 2009. South Florida Water Management District. Personal MaxQDA (Documents).

—. 2010a. South Florida Water Management District. Personal MaxQDA (Documents).

—.2010b. South Florida Water Management District. Personal MaxQDA (Documents).

_. 2010c. South Florida Water Management District. Personal MaxQDA (Documents).

—. 2010d. South Florida Water Management District. Personal MaxQDA (Documents).

- 2010e. South Florida Water Management District. Personal MaxQDA (Documents).

"Meeting Minutes, Water Resources Advisory Commissio (WRAC) Adaptive Protocols for Lake Okeechobee Regulation Schedule 2008, Meeting Minutes.” 2009. South Florida Water Management District.

"Meeting Minutes, Water Resources Advisory Committee (WRAC)." 2009. South Florida Water Management District. Personal MaxQDA (Documents).

"Monthly Meeting Minutes, Water Resources Advisory Committee (WRAC)." 2012. South Florida Water Management District. Personal MaxQDA (Budgets). 
"Robust Decision Making Workshop Notes." 2014. South Florida Water Management District headquarters, West Palm Beach.: South Florida Water Management District. Personal MaxQDA (Documents). 
VITA

DUMITRITA SUZANA MIC

Born, Romania

1999-2003

B.A., Human Geography

Bucharest University

Romania

2007-2010

M.S., Comparative Sociology

Florida International University

Miami, FL

Research Assistant, Institute for Public Opinion

Research, Florida International University, Miami, FL

2010-2015

Doctoral Candidate, Florida International University

Miami, FL

National Science Foundation, Dissertation Improvement Grant in Cultural Anthropology

FIU, Morris and Anita Broad Fellowship

Research Assistant, Urban Long Term Research

Area, Florida International University

Miami, FL

\section{PRESENTATIONS}

Suzana D. Mic. 2014. Climate Change Governance in Miami, Florida and the Question of Scale. Dimensions of Political Ecology Conference, Lexington KT.

Peter R. Craumer, Hugh Gladwin and Suzana D. Mic. 2014. The Sea in The 'Hood: Spatio-Temporal Modeling of Water Level and Settlement in Miami-Dade County, FL. Association of American Geographers Annual Meeting, Tampa FL.

Suzana D. Mic. 2010. Water in a Changing Climate. Freshwater Sustainability Workshop. Florida International University 